MIGUEL ANGEL DUTRA LACROIX

USO DE CÉLULAS FOTOVOLTAICAS DE FILMES FINOS PARA GERAÇÃO DE ENERGIA ELÉTRICA EM EDIFÍCIOS URBANOS: ESTIMATIVA DE POTENCIAL 
MIGUEL ANGEL DUTRA LACROIX

\section{USO DE CÉLULAS FOTOVOLTAICAS DE FILMES FINOS PARA GERAÇÃO DE ENERGIA ELÉTRICA EM EDIFÍCIOS URBANOS: ESTIMATIVA DE POTENCIAL}

Dissertação apresentada à Escola
Politécnica da Universidade de São
Paulo para obtenção de título de
Mestre em Ciências.

Área de Concentração:

Engenharia Elétrica - Sistemas de Potência

Orientador: Prof. Dr. Marco Antonio Saidel

São Paulo 
Este exemplar foi revisado e corrigido em relação à versão original, sob responsabilidade única do autor e com a anuência de seu orientador.

São Paulo, 21 de junho de 2013.

Assinatura do autor

Assinatura do orientador

Dutra Lacroix, Miguel Angel

Uso de células fotovoltaicas de filmes finos para geração de energia elétrica em edifícios urbanos: estimativa de potencial / M.A. Dutra Lacroix. - versão corr. -- São Paulo, 2013. $105 \mathrm{p}$.

Dissertação (Mestrado) - Escola Politécnica da Universidade de São Paulo. Departamento de Engenharia de Energia e Automação Elétricas.

1. Energia solar 2. Filmes finos 3 . Geração de energia elétric: I. Universidade de São Paulo. Escola Politécnica. Departamento de Engenharia de Energia e Automação Elétricas II. t. 


\section{DEDICATÓRIA}

Dedico este trabalho a meus pais, Graciana (em memória), Saul e ao engrandecimento deste país maravilhoso, Brasil. 


\section{AGRADECIMENTOS}

Ao professor Marco Antonio Saidel, pela orientação e pelo constante estímulo transmitido durante todo o trabalho.

A minha esposa Ângela Izabel pela compreensão e paciência.

Aos meus filhos, Júlia pelas correções de português e a Eduardo pelo fato de ser um filho maravilhoso.

A meu sobrinho Jean-Esteban Liberek pelo acesso ao acervo técnico da Escola Politécnica Federal de Lausanne na Suíça.

Aos amigos Eduardo Lorenzetti Pellini, Neide Albertini, Ana Maria Badiali e a todos que colaboraram direta e indiretamente, na execução deste trabalho. 
Não importa se a estação do ano muda... Se o século vira, se o milênio é outro.

Se a idade aumenta...

Conserva a vontade de viver, não se chega a parte alguma sem ela.

(Fernando Pessoa) 


\section{RESUMO}

Nas últimas décadas, sistemas de suprimento de energia que utilizam recursos renováveis têm sido estudados e empregados como opção para o fornecimento de energia elétrica. Devido aos avanços da tecnologia fotovoltaica, associada à diminuição de custos e maior conhecimento de seu desempenho, os sistemas fotovoltaicos apresentam-se como uma opção tecnicamente promissora.

Neste contexto, a energia solar fotovoltaica, que, além de gerar eletricidade de forma distribuída também vem ganhando cada vez mais espaço no mercado mundial. Esta tecnologia evita as emissões de gases poluentes e é uma fonte alternativa que diversifica a matriz energética.

Para complemento da energia hidrelétrica é necessária uma fonte energética com várias características ecologicamente corretas, a energia solar fotovoltaica é uma dessas fontes, pois é limpa (não poluente), inesgotável, silenciosa, estática, distributiva, simples em sua operação, possui características modulares podendo-se integrar as edificações.

Para viabilizar sua implantação nas edificações, vários países, inclusive o Brasil, também buscam soluções para o futuro, elaborando estudos para avaliar a eficácia dessa tecnologia.

Adicionalmente, como a energia é cada vez mais necessária para o desenvolvimento humano, utilizar a fonte de geração próxima ao ponto de consumo é uma maneira eficaz de reduzir as perdas por transmissão e distribuição.

Esta dissertação tem por objetivo apresentar os conceitos, aspectos e aplicações das células solares de filmes finos na inserção como gerador fotovoltaico de energia elétrica integrada a estrutura das edificações.

O foco principal do tema da dissertação é o estudo de área disponível na edificação, estimando o potencial fotovoltaico de geração existente no envoltório.

Através desta análise, pode-se quantificar a contribuição energética de uma unidade geradora fotovoltaica para a redução de consumo energético na rede em que a edificação estiver conectada.

Palavras-chave: Geração de energia elétrica. Células fotovoltaicas de filmes finos. 


\section{ABSTRACT}

In recent decades, energy supply systems that use renewable resources have been studied and used as an option for the supply of electricity.

Due to advances in photovoltaic technology, coupled with lower costs and greater knowledge of its performance, photovoltaic systems are presented as an option technically promising.

In this context, photovoltaic solar energy, this, besides generating electricity in distributed also gaining more and more space in the world market.

This technology avoids the emissions of greenhouse gases and is an alternative source to diversify the energy matrix.

To complement the hydropower energy supply is needed with various features eco-friendly, photovoltaic solar energy is one of those sources, because it is clean (clean) endless, silent, static, distributive, simple in its operation, has modular features can to integrate the buildings.

To enable its deployment in buildings, several countries, including Brazil, also look for solutions for the future, preparing studies to evaluate the effectiveness of this technology.

Additionally, energy is increasingly necessary for human development, using the power generation near the point of consumption is an effective way to reduce transmission and distribution losses.

This paper aims to present the concepts, issues and applications of thin film solar cells in photovoltaic generator insertion as power integrated structure of buildings.

The main focus of the dissertation topic is the study of the available area in the building, estimating the potential of photovoltaic generation in existing wrap.

Through this analysis, one can quantify the energy contribution of a photovoltaic generating unit to reduce energy consumption in the network in which the building is connected.

Keywords: Electric power generation, photovoltaic cells thin film. 


\section{LISTA DE ILUSTRAÇÕES}

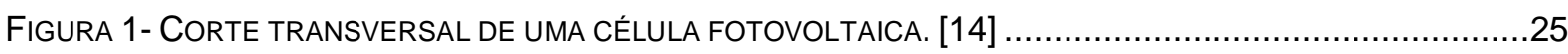

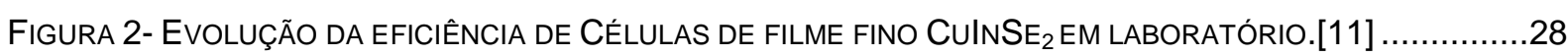

$\begin{array}{ll}\text { A) SILÍCIO CRISTALINO [SIEMENS SOLAR INDUSTRIES] } & \text { B) FILMES FINOS [SOLARION.DE] ...............31 }\end{array}$

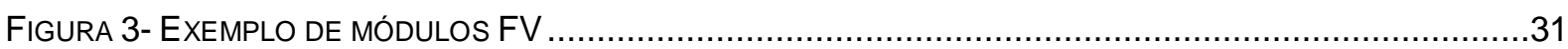

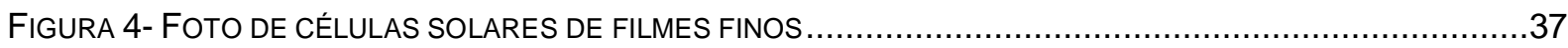

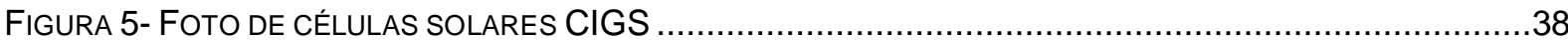

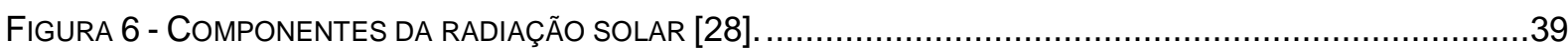

FIGURA 7- IRRADIÂNCIA EXTRATERRESTRE SOBRE UMA SUPERFÍ́CIE HORIZONTAL [35]. .............................42

FIGURA 8- POSICIONAMENTO DO SOL RELATIVAMENTE À SUPERFÍCIE HORIZONTAL [33].............................43

FIGURA 9- ÂNGULO DE INCIDÊNCIA NUMA SUPERFÍ́CIE INCLINADA E ORIENTADA [35] .................................44

FIGURA 10 - ÂNGULOS DE INCIDÊNCIA SOLAR: SOMBRA DE UMA COLINA (HILL SHADE) E PROJEÇÃO DE

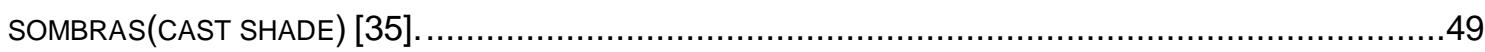

FIGURA 11 - DETERMINAÇÃO DA PROJEÇÃO DE SOMBRAS (CAST SHADE) [35] .....................................50

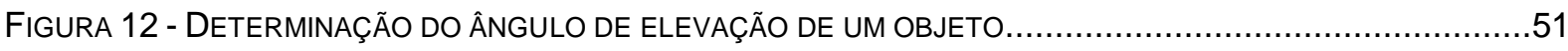

FIGURA 13 - INTEGRAÇÃO DE VÁRIOS TIPOS DE CAMADAS (LAYERS) NUM SIG (38). .................................53

FIGURA 14 - REPRESENTAÇÃO DA CRIAÇÃO DE EDIFíCIOS SOBRE UM DTM [39] .....................................54

FIGURA 15 - FLUXOGRAMA DO MODELO DE CÁLCULO DE GERAÇÃO FOTOVOLTAICA EM AMBIENTE URBANO.....55

FIGURA 16 - REPRESENTAÇÃO DE UMA SUPERFÍCIE COM MALHA DE PONTOS (MESH POINTS) E GRADE (LATTICE)

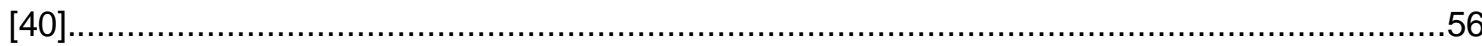

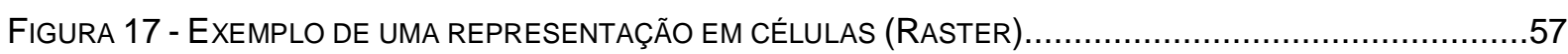

FIGURA 18 - ILUSTRAÇÃO DA FUNÇÃO MOSAIC DO PROGRAMA ARCGIS. .........................................58

FIGURA 19 - ANÁLISE DO FENÔMENO PROJEÇÃO DE SOMBRA (CAST SHADE) ..........................................59

FIGURA 20 - REPRESENTAÇÃO EM UM EDIFÍCIO DA VISIBILIDADE ENTRE CÉLULAS......................................60

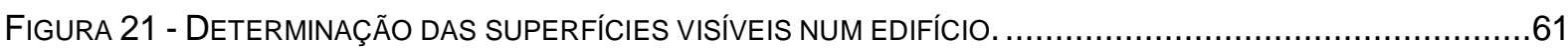

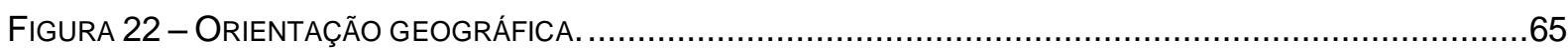

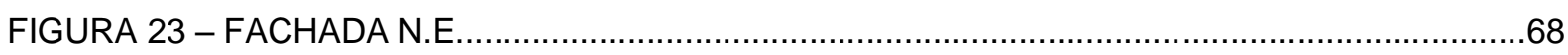

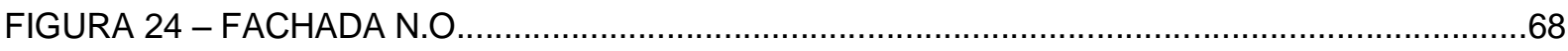

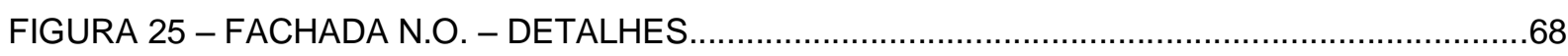

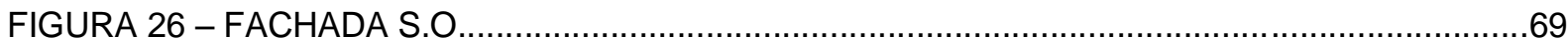

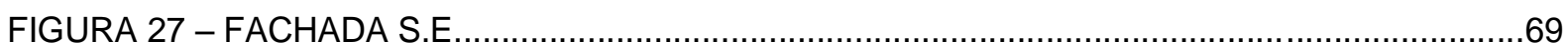

FIGURA 28 - 22/06/2011- INCIDÊNCIA DOS RAIOS DE SOL...................................................70

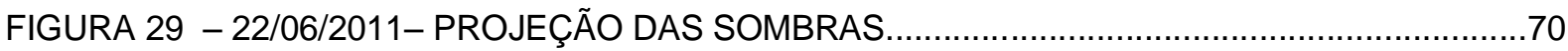

FIGURA 30 - 23/09/2011- INCIDÊNCIA DOS RAIOS DE SOL..................................................71

FIGURA 31 - 23/09/2011- PROJEÇÃO DAS SOMBRAS..............................................................

FIGURA 32 -21/12/2011- INCIDÊNCIA DOS RAIOS DE SOL....................................................72

FIGURA 33 -21/12/2011- PROJEÇÃO DAS SOMBRAS .............................................................

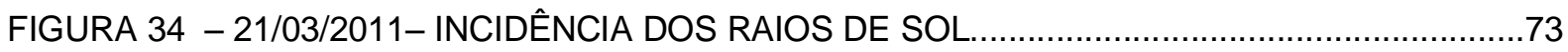

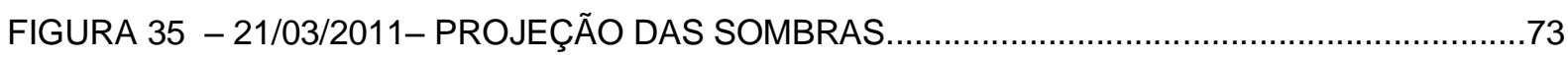


FIGURA 36 - CARACTERÍSTICAS ELÉTRICAS DOS MÓDULOS [49]. 


\section{LISTA DE GRÁFICOS}

GráfICO 1 - RADIAÇÃO SOLAR NO PLANO HORIZONTAL, 2011. [43]............................76 


\section{LISTA DE TABELAS}

TABELA 1 - CUSTOS COM A PRODUÇÃO DE ENERGIA ELÉTRICA. 18

TABELA 2 - EFICIÊNCIA DE CÉLULAS E MÓDULOS DE CIGS OBTIDAS EM LABORATÓRIOS E EM DIFERENTES EMPRESAS. [17] 29

TABELA 3 - EFICIÊNCIA E TEMPO DE VIDA ÚTIL DAS CÉLULAS DE FILMES FINOS. 30

TABELA 4 - CONSUMO MENSAL DO ANO 2011. 66

TABELA 5 - ÁREA DISPONÍVEL PARA INSTALAÇÃO DE CÉLULAS - MÓDULOS FV. .67

TABELA 6 - VARIAÇÃO DA DECLINAÇÃO MAGNÉTICA [42]. .74

TABELA 7 - RADIAÇÃO MÉDIA NO PLANO HORIZONTAL [KWH/M2. DIA] .75

TABELA 8 - SÃO PAULO, MÓDULOS INSTALADOS NA HORIZONTAL .78

TABELA 9 - SÃO PAULO, MÓDULOS INSTALADOS A 24, IGUAL À LATITUDE ...78

TABELA10 - SALVADOR, MÓDULOS INSTALADOS NA HORIZONTAL .79

TABELA 11 - SALAVADOR, MÓDULOS INSTALADOS A 13ㅇ, IGUAL À LATITUDE ...79 TABELA 12 - PORTO ALEGRE, MÓDULOS INSTALADOS NA HORIZONTAL 80

TABELA 13 - PORTO ALEGRE, MÓDULOS INSTALADOS A 30, IGUAL À

LATITUDE. .80

TABELA 14 - IRRADIAÇÃO TOTAL MENSAL PARA O ESTUDO DE CASO COM A INSTALAÇÃO DOS MÓDULOS Á 90…

TABELA 15 - ESTIMATIVA DE GERAÇÃO MENSAL DE ELETRICIDADE E PORCENTAGEM DO CONSUMO SUPRIDO PELO SISTEMA FV. .86 TABELA 16 - EMISSÕES DE $\mathrm{CO}_{2}$ NAS INSTALAÇÕES FV COM FILMES FINOS (CIGS) [52] .89

TABELA 17 - QUANTIDADE DE $\mathrm{CO}_{2}$ LIBERADO .90

TABELA 18 - CUSTOS DOS COMPONENTES. .91 


\section{LISTA DE SIGLAS, SÍMBOLOS E ABREVIATURAS.}

$\mu \mathrm{m}$

$\mathrm{a}-\mathrm{Si}: \mathrm{H}$

ArcGIS

a-Si

BIPV

$\mathrm{CC}: \mathrm{CA}$

CdTe

CIGS

CIS

$\mathrm{CO}_{2}$

c-Si

CulnSe 2

DEM

DTM

EVA

FV

GEE

high-tech

ISE/Fraunhofer

$\mathrm{km}^{2}$
Unidade de comprimento do Sistema Internacional de Unidades. Está definido como um milionésimo de metro $\left(1 \times 10^{-6}\right.$ $\mathrm{m})$.

Silício amorfo hidrogenado

É o nome de um grupo de programas informáticos e que constitui um sistema de informação geográfica.

Silicio amorfo

Edifício fotovoltaico Integrado. (Building Integrated Photovoltaic)

Corrente Contínua e Corrente Alternada

Telureto de cádmio

Material semicondutor composto de cobre, índio, gálio e selénio (muitas vezes abreviado "CIS")

Diselenieto de Cobre e Índio

Dioxido de Carbono

Silício cristalino

Cobre, Indio, Gálio e Selenio

Modelo Digital de Elevação

Modelo Digital de Terreno

Etileno Vinil Acetato

Fotovoltaicos

Gases com efeito de estufa

De alta tecnologia

Instituto Fraunhofer para Sistemas de Energia Solar, Freiburg im Breisgau, Alemanha.

Unidade de Superfície. 
MPPT

NREL

SHGC

SIG

STC

STPV

$T \& D$

TSET

U.S. Census Bureau

UE

UV
Seguidor do ponto de máxima Potência

Laboratório Nacional de Energia Renovável

Coeficiente de ganho de calor solar

Sistema de Informacao Geografica

Condições de Teste Padrão

Semi transparente fotovoltaicas

Transmissão e Distribuição de Energia Elétrica.

Transmitância Total de Energia Solar

O United States Census Bureau (oficialmente Bureau of th Census como definido em documentação do Departamento de Comércio). É a agência governamental encarregada pelo censo nos Estados Unidos da América.

Uniao Europeia

Ultravioleta 


\section{LISTA DE SÍMBOLOS}
A
Área do módulo fotovoltaico
$d_{n}$
Dia do ano
$\mathrm{E}_{\mathrm{FV}}$
Energia total produzida
$\mathrm{H}$
Irradiação global
h
Irradiância global
$\mathrm{H}_{0}$
Irradiação extraterrestre
$\mathrm{H}_{\mathrm{b}}$
Irradiação direta
$h_{b}$
Irradiância direta
$\mathrm{H}_{\mathrm{d}}$
Irradiação difusa
hd
Irradiância difusa
$\mathrm{H}_{\mathrm{t}}$
Irradiação total
$h_{t}$
Irradiância total
$\mathrm{H}_{\beta}, \alpha$
Irradiação incidente no plano do módulo fotovoltaico
$\mathrm{H \rho}$
Irradiação refletida pelo solo
hp
Irradiância refletida pelo solo
$I_{0}$
Irradiância extraterrestre
IsC
Constante solar
$\mathrm{K}_{\mathrm{T}}$
Indice de atenuação
$\mathrm{R}_{\mathrm{b}}$
Coeficiente de correção da irradiação direta
W
Velocidade angular da Terra
$\alpha$
Ângulo de azimute da superfície
$\beta$
Ângulo de inclinação da superfície 


$\begin{array}{ll}Y & \text { Ângulo de elevação de um objeto } \\ \gamma_{s} & \text { Elevação solar } \\ \delta & \text { Declinação } \\ \eta_{\mathrm{FV}} & \text { Eficiência do módulo fotovoltaico } \\ \eta_{\mathrm{MPPT}} & \text { Eficiência total do sistema inversor } \\ \theta_{\mathrm{s}} & \text { Ângulo de incidencia solar } \\ \theta_{z} & \text { Distância zenital } \\ \rho & \text { Refletividade do solo } \\ \Phi & \text { Latitude } \\ \psi \mathrm{sS} & \text { Azimute solar } \\ \omega & \text { Ângulo solar } \\ \omega_{\mathrm{p}} & \text { Ângulo de por do Sol } \\ \omega_{\mathrm{pp}} & \text { Ângulo de por do sol relativamente ao módulo FV } \\ \omega_{\mathrm{s}} & \text { Ângulo de saída do Sol } \\ \omega_{\mathrm{sp}} & \text { Ângulo de saída do sol relativamente ao módulo FV }\end{array}$




\section{SUMÁRIO}

1 INTRODUÇÃO 17

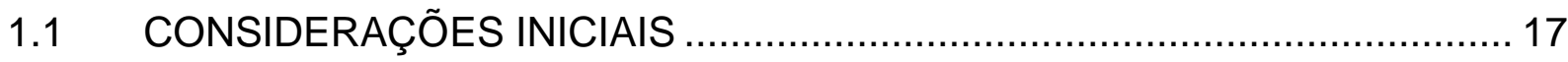

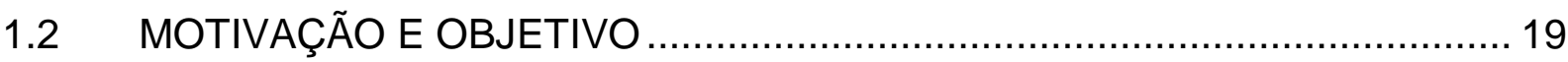

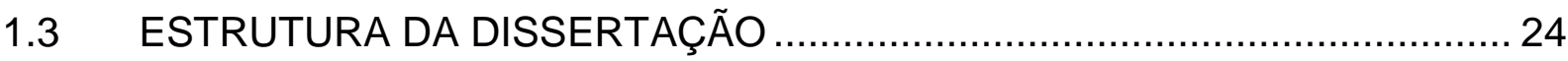

2 ESTADO DA ARTE DAS CÉLULAS SOLARES DE FILMES FINOS..........25

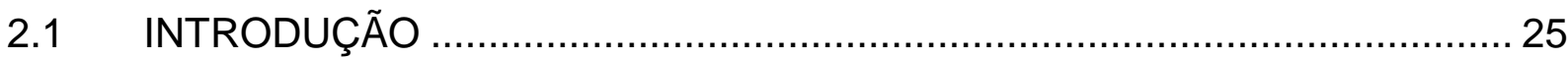

2.2 CÉLULAS FOTOVOLTAICAS DE FILMES FINOS …................................... 30

2.2.1 Características das células fotovoltaicas de filmes finos ...............................32

2.3 TIPOS DE CÉLULAS DE FILMES FINOS ................................................ 33

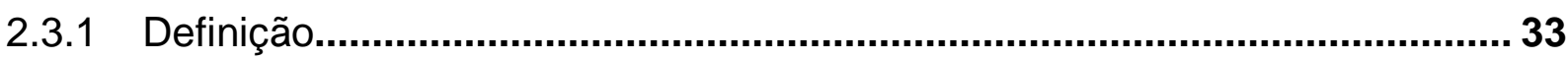

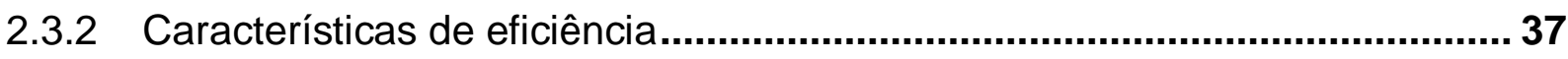

3 CONCEITOS SOBRE CÁLCULO DE GERAÇÃO FOTOVOLTAICA............39

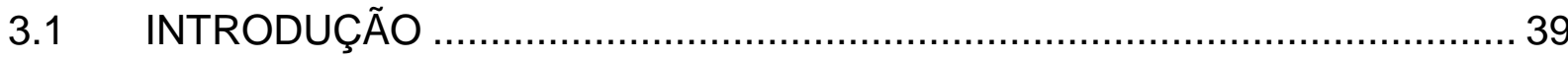

3.2 RADIAÇÃO SOLAR INCIDENTE NUMA SUPERFÍCIE …..........................40

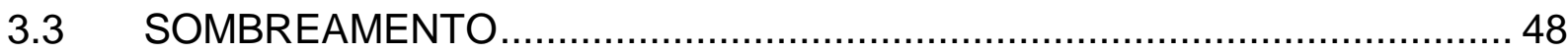

3.4 ESTIMATIVA DA GERAÇÃO FOTOVOLTAICA …..................................... 51

3.5 MODELAGEM DE PREVISÃO DA GERAÇÃO FOTOVOLTAICA EM

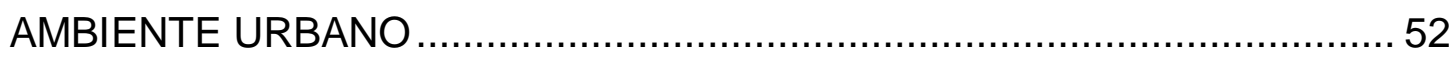

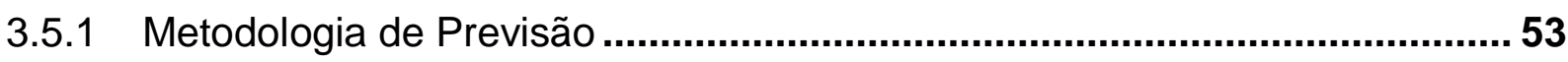

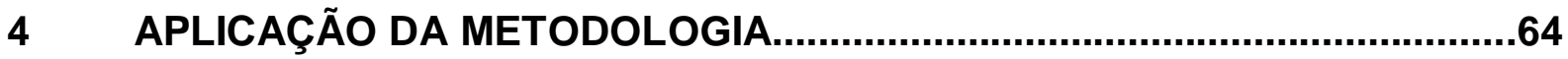

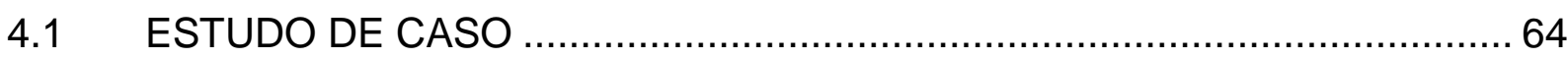

4.2 DADOS DE IRRADIAÇÃO SOLAR PARA O LOCAL DE ESTUDO .....................74

4.2.1 Radiação solar incidente no local da aplicação ................................................77 
4.3 CARACTERÍSTICA DA CÉLULA - MÓDULO SOLAR DE FILME FINO UTILIZADO

4.3.1 Características elétricas da célula - módulo solar de filme fino utilizado.

4.4 ESTIMATIVA DO POTENCIAL DE GERAÇÃO COM A IMPLEMENTAÇÃO DOS MÓDULOS FV

4.4.1 Estimativa de geração fotovoltaica .85

4.4.2 Contribuição da geração fotovoltaica na redução do consumo de energia elétrica proveniente da rede pública.

4.4.3 Contribuição da geração fotovoltaica na redução da emissão de gás $\mathrm{CO}_{2}$ (dióxido de carbono).

4.5 CONCLUSÕES 90

5 CONSIDERAÇÕES FINAIS 93

5.1 ANÁLISE 93

5.2 CONCLUSÕES 94

5.3 TRABALHOS FUTUROS 95

REFERÊNCIAS 96

ANEXOS 102 


\section{INTRODUÇÃo}

\subsection{CONSIDERAÇÕES INICIAIS}

A preocupação com os problemas ambientais causados pela utilização de fontes convencionais de energia baseadas em combustíveis fósseis, aliada à iminente questão do aquecimento global serviram de motivação para a elaboração deste trabalho.

A sociedade começa a questionar os impactos causados pela Geração Centralizada, estando em desacordo com as grandes emissões dióxido de carbono $\left(\mathrm{CO}_{2}\right)$ na atmosfera promovido pelas Termoelétricas, os grandes lagos das Hidroelétricas e as extensas linhas de transmissão (ainda mais quando estão próximas aos centros urbanos).

Soma se a isto, uma população em franco crescimento, que implica no aumento da demanda energética, aliada às pressões econômicas e industriais pelo desenvolvimento.

De acordo com os dados publicados pelo U.S. Census Bureau, em julho de 2012 a população mundial é de aproximadamente 7,028 bilhões e até 2050 a estimativa é de que sejam 9,200 bilhões de habitantes no planeta. [2]

O Sol, além de fonte de vida, é a origem de todas as formas de energia que o homem vem utilizando durante sua historia e pode ser a resposta para a questão do abastecimento energético no futuro, uma vez que aprendemos a aproveitar de maneira racional a luz que esta estrela constantemente derrama sobre nosso planeta.

Uma das possíveis formas de aproveitamento da energia solar é conseguida através da geração fotovoltaica de energia elétrica.

Tradicionalmente atrativa em áreas onde a rede elétrica convencional não está presente (sistemas isolados ou autônomos), esta tecnologia começa a ser interessante em aplicações conectadas à rede elétrica pública [3]. 
Os edifícios comerciais, residenciais e públicos são responsáveis por aproximadamente $46,9 \%$ de todo consumo de energia elétrica do Brasil [4].

A postura da arquitetura sustentável busca reduzir e harmonizar os impactos prejudiciais ao ambiente.

Portanto, utilizar o edifício construído para a geração de energia elétrica é uma maneira eficiente de contribuir para o desenvolvimento sustentável e a tecnologia fotovoltaica possibilita tal ação.

A principal barreira para a disseminação do uso da tecnologia fotovoltaica é seu custo elevado quando comparado a outras fontes, inclusive, quando tomado como referência os custos com a produção de energia elétrica através das usinas convencionais, como é possível verificar na tabela 1 ;

Tabela 1 - Custos com a produção de energia elétrica.

\begin{tabular}{|c|c|c|c|}
\hline $\begin{array}{c}\text { Preço da geração elétrica } \\
\text { (R\$/kWh) }\end{array}$ & 2005 & $2014-2020$ & 2040 \\
\hline Combustíveis Fósseis & $0,10-0,12$ & $0,15-0,18$ & $0,17-0,23$ \\
\hline Nuclear & $0,10-0,15$ & $0,09-0,18$ & $0,09-0,015$ \\
\hline Hidroelétrica & & $0,122-0,113$ & \\
\hline Eólica & $0,19-0,23$ & $0,13-0,15$ & $0,08-0,10$ \\
\hline Solar Térmica & 0,44 & 0,15 & 0,08 \\
\hline Solar Fotovoltaica & $0,51-1,03$ & $0,13-0,26$ & $0,08-0,15$ \\
\hline
\end{tabular}

Fonte: Salamoni, 2009. (Atualizado para valores de março 2013)

Neste sentido, a geração fotovoltaica poderá favorecer a redução dos picos de demanda, principalmente nos meses e horários de maior incidência solar que coincidem com os períodos de maior consumo das edificações comerciais, principalmente devido à utilização de equipamento de ar condicionado [1]. 


\subsection{MOTIVAÇÃO E OBJETIVO}

A expansão acentuada do consumo de energia, embora possa refletir o aquecimento econômico e a melhoria da qualidade de vida, tem aspectos negativos.

Um deles é a possibilidade do esgotamento dos recursos utilizados para a produção de energia.

Outro é o impacto ao meio ambiente produzido por essa atividade.

Finalmente, são os elevados investimentos exigidos na pesquisa de novas fontes e construção de novas usinas.

No Brasil, país tropical, com a maioria dos dias do ano com sol, utilizar essa fonte de energia, pode ser a solução para não depender da natureza finita dos combustíveis fósseis já que o consumo mundial de energia se baseia quase em sua totalidade nesse tipo de fonte primária.

A inserção de geradores convencionais de energia geralmente ocorre em locais afastados dos grandes centros urbanos, principalmente devido à disponibilidade dos recursos utilizados, e tende a acarretar problemas para o entorno como poluição do ar, sonora e visual.

No entanto, com a energia cada vez mais necessária para o desenvolvimento humano, utilizar a fonte de geração próxima ao ponto de consumo é uma maneira eficaz de reduzir as perdas por transmissão e distribuição T\&D. [4]

Em um país com as dimensões do Brasil (8,5 milhões de $\left.\mathrm{km}^{2}\right)$, a infraestrutura de T\&D ( $\approx 107 \mathrm{mil} \mathrm{km}$, só em transmissão), bem como as perdas de energia associadas, não são desprezíveis e devem ser consideradas.

Com uma capacidade instalada de 117.135 MW (2011) [4], o sistema interligado nacional é um dos maiores e mais complexos sistemas de transmissão de energia do mundo. Mesmo assim, em 2001, com o crescimento acentuado da demanda energética devido a condições econômicas favoráveis e a falta de novos investimen- 
tos em infraestrutura, houve falta de energia e um consequente racionamento no fornecimento de energia elétrica em algumas regiões do Brasil. Anos mais tarde, em 2009, dezoito estados brasileiros ficaram total ou parcialmente sem energia elétrica por cinco horas, trazendo de volta o medo do racionamento energético. Percebe-se, então, o risco baseado em grande parte na mesma fonte energética, neste caso, na fonte hídrica [4].

Diante destes fatos, a tecnologia fotovoltaica integrada à edificação apresentase como uma opção interessante de geração energética próxima ao ponto de consumo, não ocupando área extra e sob o ponto de vista ambiental, não interferindo negativamente no entorno em que se encontra. Pelo contrário, a utilização desta tecnologia tanto sobreposta à estrutura existente, como sendo o próprio material de vedação, só tem a acrescentar valor estético à edificação.

Qualquer superfície de um edifício que esteja exposta a radiação solar é "candidata" a integração de módulos FV. Muitos edifícios incorporam elementos construtivos adicionais em paredes, telhados e janelas. Todas estas superfícies podem proporcionar outros benefícios aos sistemas de células (BIPV). Além da produção local de energia contribuem também com o isolamento térmico, design arquitetônico [5], sombreamento e proteção solar [6].

A integração de módulos FV num edifício pode ser feita de várias formas. As mais comuns são em:

- Telhados;

- Fachadas;

- Átrios, clarabóias;

- Dispositivos solares de sombreamento.

Nestas diferentes aplicações pode-se tirar partido da energia solar da seguinte forma [7]:

Edifícios podem integrar à sua fachada módulos solares que geram, de forma descentralizada e junto ao ponto de consumo, energia elétrica pela conversão direta da luz do sol e servem 
ao mesmo tempo como materiais de revestimento destas fachadas e coberturas. Sistemas deste tipo podem alimentar equipamentos eletrônicos, iluminação, aparelhos de pouco consumo, e, por outro lado, utiliza a rede elétrica como backup quando a quantidade de energia gerada não é suficiente para atender a instalação consumidora.

A fachada é a parte estrutural é a primeira impressão de um edifício. No que diz respeito à integração de módulos de filmes finos, nas fachadas dos edifícios, estes podem enriquecer a diversidade de soluções arquitetônicas. Hoje em dia, às fachadas de vidro estabelecem uma ligação para o exterior, e as inovadoras células solares podem ser integradas nos vidros, dando-Ihes assim uma nova função. [8]

Uma questão crítica para a geração fotovoltaica é quanto ao sombreamento nos módulos FV. Podem existir árvores, paredes, outros módulos e edifícios, que em determinadas ocasiões, quando os módulos se integram na arquitetura dos edifícios, podem originar sombras, provocando desta forma uma redução da capacidade de geração.

Os módulos solares fotovoltaicos geram energia em corrente contínua. Assim sendo, se faz necessário o uso de um equipamento eletrônico conhecido como inversor, ou conversor c.c./c.a., para que se obtenha tensão em corrente alternada.

Módulos solares fotovoltaicos de filmes finos fabricados sobre um substrato de vidro são basicamente os mesmos produtos que os painéis de vidro revestido por películas que são comumente utilizados na construção civil; existe assim a expectativa em curto prazo de que se produzidos em grande escala os custos venham a declinar de forma acentuada.

Os sistemas solares fotovoltaicos integrados as edificações urbanas e interligados ao sistema de distribuição oferecem uma série de vantagens ao setor elétrico, que justifica a sua utilização, muitas das quais estão relacionadas a custos evitados e que não vêm sendo atualmente quantificadas ou consideradas. Dentre as justificativas pode-se destacar: 
- perdas por transmissão e distribuição de energia são minimizadas, bem como os investimentos nas respectivas linhas;

- edifícios com dispositivos solares fotovoltaicos não apresentam necessidade de área física adicional dedicada, uma vez que a área necessária para a instalação dos dispositivos já é ocupada pela edificação;

- edifícios solares fotovoltaicos têm a capacidade de disponibilizar a energia sobressalente no sistema de distribuição com picos diurnos, visto que a geração FV acontece no decorrer do dia [11].

Considerando as elevadas tarifas energéticas e a grande disponibilidade do recurso solar em todo o país (o local menos ensolarado no Brasil recebe cerca de $40 \%$ mais energia solar anualmente do que a Alemanha) [12]; a natureza complementar da geração solar com a hidráulica (sazonalidade) e a característica distribuída e junto ao ponto de consumo da geração solar integrada a edificações urbanas, a tecnologia fotovoltaica ganha pontos quando comparada a fontes convencionais de energia, mesmo com seu custo inicial de instalação ainda elevado. Além disso, a concomitância entre geração fotovoltaica e consumo energético, em centros urbanos com integração de módulos fotovoltaicos, contribui para o alívio de carga no sistema de distribuição convencional, evitando custos de expansão de rede e reduzindo a probabilidade de quedas de fornecimento de energia elétrica [10].

Geradores fotovoltaicos distribuídos estrategicamente apresentam mínima capacidade ociosa de geração: por sua grande modularidade e curtos prazos de instalação, podem ser considerados um just-in-time ${ }^{1}$ de adição de capacidade de geração.

Na Alemanha, especificamente na cidade de Freiburg (Estado Federal de Baden-Württemberg) foi realizado em 2006 um programa de solarização de telhados chamado "Solarsiedlung Schlierberg" no qual cada residência recebeu um sistema fotovoltaico, totalizando $440 \mathrm{kWp}$ conectados a rede elétrica. Esta experiência serviu para que se investigasse a relação entre uma grande quantidade de geração fotovol-

\footnotetext{
${ }^{1}$ Termo usado para indicar que um processo é capaz de responder instantaneamente à demanda.
} 
taica conectada a uma rede de baixa tensão e pode-se perceber que tal ação pode ser realizada sem problemas. [13]

Esta dissertação tem o objetivo geral de mostrar e avaliar as possíveis vantagens e desvantagens da inserção de um gerador fotovoltaico num edifício urbano, estudar a contribuição energética na rede elétrica pública e redução na emissão de gás $\mathrm{CO}_{2}$ na atmosfera.

Os objetivos específicos desta dissertação são:

1. Caracterizar o Edifício "The Classic Tower", localizado no bairro de Vila Mariana na cidade de São Paulo, estado de São Paulo, de acordo com os seguintes itens:

- Consumo energético mensal e curva de demanda horária para o período de um ano.

- Arquitetura da edificação, com quantificação das áreas disponíveis para a integração de módulos fotovoltaicos.

2. Simular a operação de módulos solares fotovoltaicos, integrados ao edifício, através das seguintes etapas:

- Integração de módulos solares fotovoltaicos a estrutura física do edifício construído.

- Estimativa da capacidade de geração fotovoltaica instalada.

- Cálculo do potencial de geração fotovoltaica mensal.

3. Avaliar a contribuição energética de uma unidade geradora fotovoltaica inserida no meio urbano.

- Contribuição da geração fotovoltaica na redução de consumo energético do edifício.

- Redução da emissão de $\mathrm{CO}_{2}$ na atmosfera. 


\subsection{ESTRUTURA DA DISSERTAÇÃO}

Esta dissertação está estruturada em cinco capítulos:

O primeiro capítulo apresenta a introdução, motivação e o objetivo.

O capítulo dois descreve o estado da arte das células solares de filmes finos, evolução da eficiência, desempenho e tipos de células de filmes finos com apresentação dos últimos trabalhos realizados por Laboratórios e Empresas que estudam este tipo de célula e que serviram para enriquecer esta dissertação.

O capítulo três descreve os conceitos, base sobre geometria solar, como ferramenta de suporte para a geração com sistemas fotovoltaicos, incluindo sombreamentos. Também apresenta a modelagem de cálculo em ambiente urbano com a utilização de duas ferramentas computacionais.

O quarto capítulo apresenta um estudo de caso proposto com a instalação de células solares fotovoltaicas nas quatro fachadas de um edifício. Também descreve o modelo adotado que diz respeito ao cálculo da geração FV, levando-se em consideração as condicionantes associadas à localização, área envidraçada, inclinação e orientação dos módulos FV. Também esta apresentado um estudo da redução na emissão de $\mathrm{CO}_{2}$.

O capítulo cinco apresenta as considerações finais, resultados obtidos, a análise, conclusões e trabalhos futuros.

Posteriormente apresenta a lista de referências bibliográficas, obras mencionadas no decorrer do texto; e a bibliografia recomendada, textos não citados na dissertação, porém de relativa importância para o tema em questão.

Por fim, apresenta os anexos, com explicações e aprofundamentos complementares ao corpo principal do texto. 


\section{ESTADO DA ARTE DAS CÉLULAS SOLARES DE FILMES FINOS}

\subsection{INTRODUÇÃO}

Na geração fotovoltaica os fótons contidos na luz solar são convertidos em energia elétrica, por meio do uso de células solares. Este fenômeno (Efeito Fotovoltaico) foi relatado por Edmond Becquerel em 1839, quando nos extremos de uma estrutura de matéria semicondutora surge o aparecimento de uma diferença de potencial elétrico, devido à incidência de luz. Em outras palavras, a célula solar trabalha segundo o princípio de que os fótons incidentes, colidindo com os átomos de certos materiais, provoca um deslocamento dos elétrons, carregados negativamente, gerando uma corrente elétrica.

Neste processo de conversão da energia radiante em energia elétrica a célula é a unidade fundamental (Figura 1).

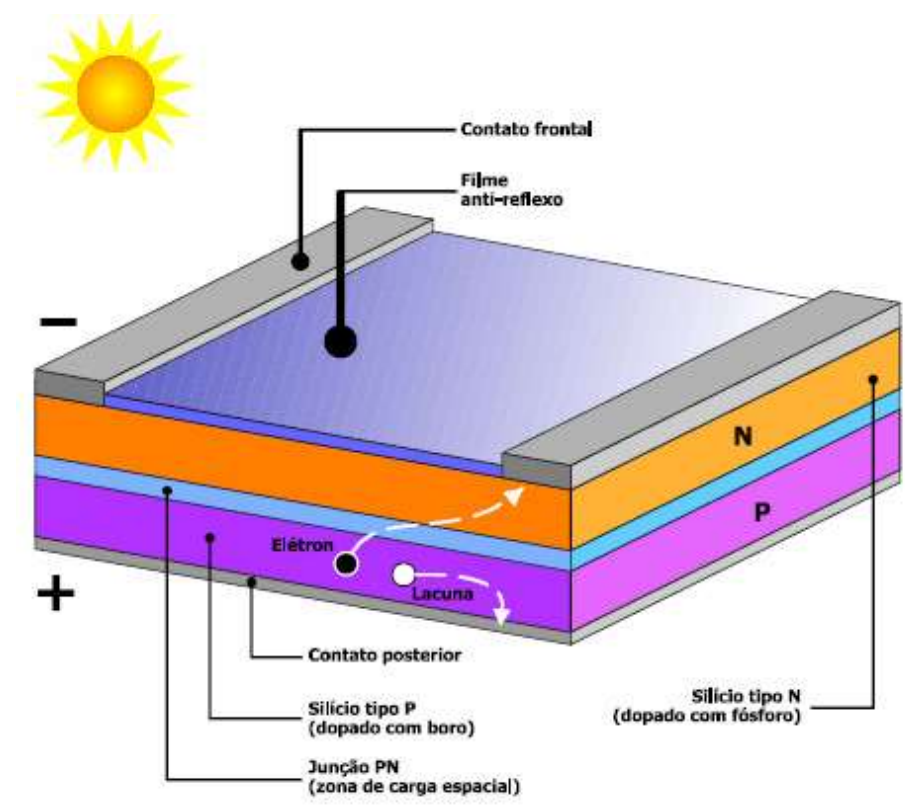

Figura 1- Corte transversal de uma célula fotovoltaica. [14] 
Dentre as diferentes células solares fotovoltaicas (FV), destacam-se por ordem decrescente de maturidade e utilização o silício cristalino c-Si; o silício amorfo hidrogenado a-Si: $\mathrm{H}$ ou simplesmente $\mathrm{a}-\mathrm{Si}$, o telureto de cádmio $\mathrm{CdTe}$ e os compostos relacionados ao dissulfeto de cobre e índio $\mathrm{CulnSe}_{2}$ ou CIS.O c-Si é a tecnologia FV mais tradicional e a única dentre as mencionadas que faz uso de laminas cristalinas. Todas as outras tecnologias estão baseadas em películas finas (filmes finos, com espessura da ordem de $1 \mu \mathrm{m}$ ) de material ativo semicondutor. Filmes finos para aplicações FV estão sendo desenvolvidos para a geração de energia elétrica por apresentarem baixos custos de produção decorrentes das quantidades diminutas de material envolvido e das pequenas quantidades de energia útil utilizada no momento da fabricação, resultando em um baixo custo de capital. Em termos de eficiência de conversão FV, a tecnologia do c-Si é, entre as tecnologias utilizadas em aplicações terrestres, a que apresenta a maior eficiência.

Devido a recentes projetos de investigação, na última década foi possível integrar esses mesmos sistemas em edifícios, locais onde o ser humano passa a maior parte da sua vida, seja em casa, no trabalho ou em lazer [15].

Grande parte do consumo de energia elétrica acontece nos edifícios, devido à necessidade de climatização e iluminação em diferentes momentos do dia e do ano. As atividades que são realizadas dentro de um edifício, desde o simples ato de aquecer uma panela com água a processos que requerem um maior dispêndio de energia, contribuem para esse grande consumo de energia.

No que diz respeito à produção de energia nos próprios locais de consumo, temos o exemplo dos sistemas FV, que apesar de ser uma tecnologia já com um certo desenvolvimento, foi apenas na década de 90 que começaram a aparecer os primeiros sistemas FV integrados em edifícios, denominados BIPV.

A tecnologia fotovoltaica baseada em óxidos ternários chamados de semicondutores de banda larga teve uma grande evolução nestes últimos anos. $O$ primeiro trabalho baseado em $\mathrm{CulnSe}_{2}$ (CIS), mostrou que este material era complexo, mas bastante promissor na tecnologia de filme fino [16]. 
Na Figura 2 visualiza-se a evolução e pesquisa da eficiência de Células de filme fino $\mathrm{CulnSe}_{2}$, assinalado com <, em diferentes Laboratórios/Empresas ao longo dos anos [11].Existem diferentes tecnologias e materiais semicondutores em investigação ou produção industrial, como o silício amorfo, silício policristalino, CdTe(telureto de cádmio), CIS (Cu,In,Se 2$)$, CIGS(Cu,In, Ga, $\left.\mathrm{Se}_{2}\right)$ e CISu (Cu,In, $\left.\mathrm{S}_{2}\right)$. Tipicamente, as eficiências das células FV de filmes finos é mais baixa de que as de silício cristalino, mas os custos de produção são também mais baixos, pelo que se pode atingir um preço mais reduzido por watt. Como a massa é reduzida, estes painéis são facilmente instalados, e podem ainda, ser utilizadas em materiais flexíveis. 


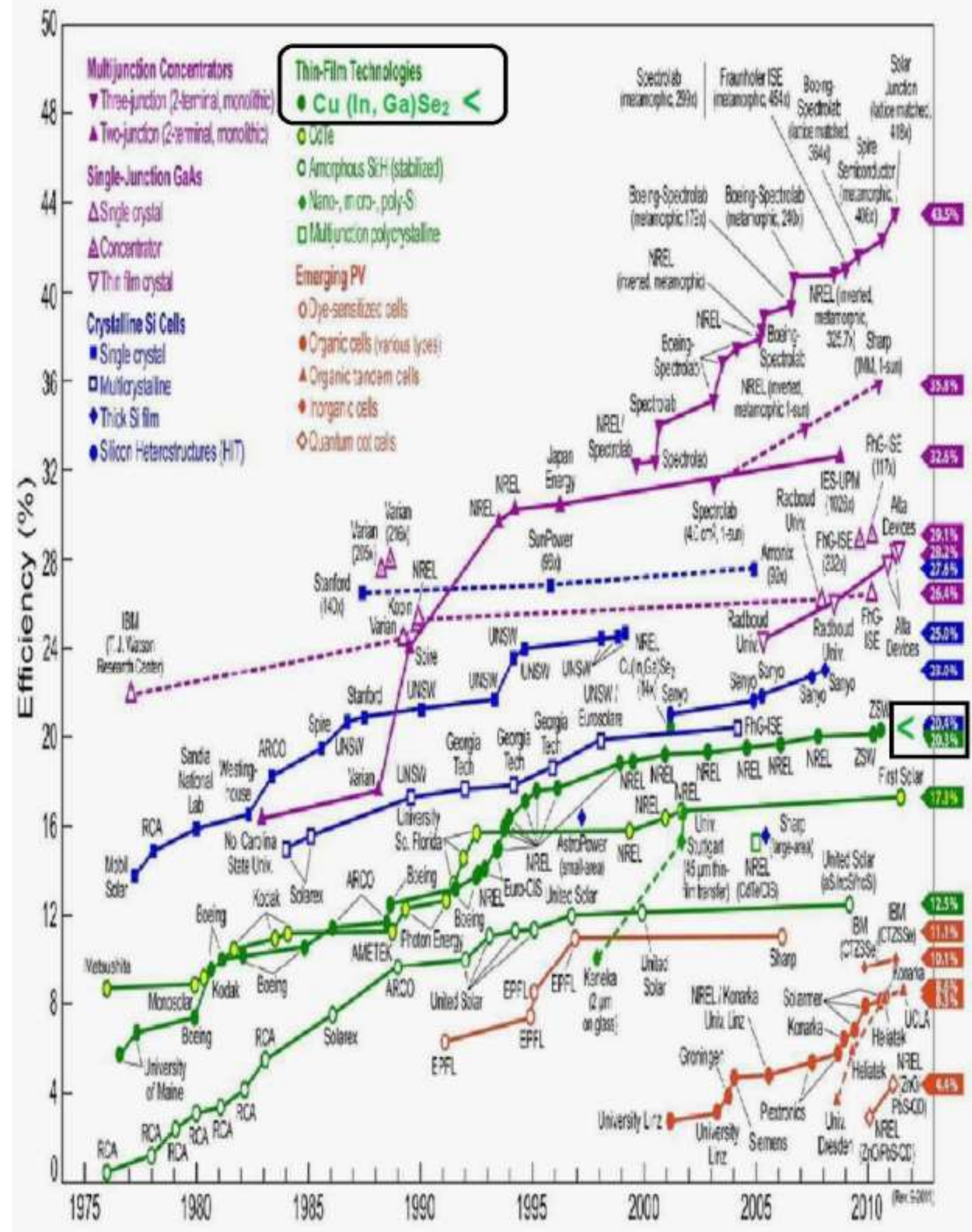

Figura 2- Evolução da eficiência de Células de filme fino CulnSe $e_{2}$ em laboratório.[11] 
Alguns dos Laboratórios e Empresas que estudam este tipo de células são a Universidade de Maine, Boeing, Euro CIS e a NREL.

A evolução de células baseadas em CIGS foi estudada por diferentes empresas e foram aplicados diferentes métodos de deposição obtendo vários valores de eficiências, como podem ser observados na Tabela 2 [17].

Tabela 2 - Eficiência de células e módulos de CIGS obtidas em laboratórios e em diferentes empresas. [17]

\begin{tabular}{|c|c|c|c|}
\hline $\begin{array}{c}\text { Processo de Fabri- } \\
\text { cação }\end{array}$ & $\begin{array}{c}\text { Eficiência da cé- } \\
\text { lula no laborató- } \\
\text { rio (\%) }\end{array}$ & $\begin{array}{c}\text { Eficiência do } \\
\text { módulo } \\
\mathbf{( \% )} / \mathbf{c m}^{2}\end{array}$ & $\begin{array}{c}\text { Laboratório/ } \\
\text { Empresa }\end{array}$ \\
\hline Precursor na Selenização & $>16$ & $12.1 / 1 \times 4$ pé $^{\mathrm{a}}$ & $\begin{array}{c}\text { Siemens,produção } \\
\text { piloto }\end{array}$ \\
\hline Películas metálicas & 18.8 & $14.7 / 18^{\mathrm{b}}$ & $\begin{array}{c}\text { Siemens,produção } \\
\text { piloto }\end{array}$ \\
\hline Coevaporação/evaporação & 17.2 & $13.9 / 90^{\mathrm{b}}$ & $\begin{array}{c}\text { NREL } \\
\text { IPE } \\
\text { ZSW, laboratório } \\
\text { de fábrica Wurth } \\
\text { Sola, produção } \\
\text { piloto }\end{array}$ \\
\hline & 16.2 & $12.7 / 800^{\mathrm{b}}$ & $\begin{array}{c}\text { EPV } \\
\text { Global Solar }\end{array}$ \\
\hline & - & $9.6 / 135^{\mathrm{a}}$ & $\begin{array}{c}\text { Angstrom Solar } \\
\text { Center }\end{array}$ \\
\hline Processos não a vácuo & $>11$ & $16.8 / 19^{\mathrm{b}}$ & \begin{tabular}{c} 
ISET Unisun \\
\hline
\end{tabular} \\
\hline
\end{tabular}

a Confirmado de forma independente por NREL

${ }^{b}$ Confirmado de forma independente por ISE/Fraunhofer

Sistemas fotovoltaicos não produzem ameaça alguma ao meio ambiente durante o seu funcionamento. Suas potenciais ameaças surgem durante a produção e descarte dos sistemas ao fim do seu tempo útil de funcionamento. 
Na Tabela 3, temos o tempo de vida útil das células solares de filmes finos.

Tabela 3 - Eficiência e tempo de vida útil das células de filmes finos.

\begin{tabular}{|l|c|c|}
\hline \multicolumn{1}{|c|}{ Tecnologia } & Eficiência (\%) & Tempo de vida (anos) \\
\hline Filmes finos de a-Si & $10-13$ & $20-30$ \\
\hline Filmes finos de CIS, CdTe & $10-18,8^{*}$ & $20-30$ \\
\hline Futuras multijunções (2020) & 30 & 30 \\
\hline
\end{tabular}

* National Renewable Energy Laboratory (NREL) .Laboratório Nacional de Energias Renováveis, EE-UU.

\subsection{CÉLULAS FOTOVOLTAICAS DE FILMES FINOS}

No mercado atual, existem basicamente duas tecnologias de módulos fotovoltaicos:

- Produtos cristalinos, Figura $3 \mathbf{a}$ - incluem as células fotovoltaicas feitas de silício cristalino, eficiência global típica entre 12\% e $15 \%$ (percentagem da energia solar convertida em eletricidade), valores atualizados em 05/08/2011 [18]. Estes produtos subdividem-se em dois tipos de tecnologias:

- Silício monocristalino - o silício que compõe as células é composto de um único cristal. A rede cristalina tem poucas imperfeições, ou seja, é praticamente homogênea. O processo de fabricação é complexo, contudo é o que proporciona maior eficiência [19];

- Silício policristalino - é formado por vários cristais. O processo de cristalização não é tão cuidadoso como o anterior, tornando- 
se assim menos dispendioso, mas apresenta eficiências ligeiramente mais baixas [19].

- Produtos de filmes finos, Figura $3 \mathbf{b}$ - constituídos tipicamente por finas camadas de material fotovoltaico colocadas num substrato de vidro, metal ou polímeros utilizando técnicas de fabricação por deposição em vácuo. Atualmente, os materiais de filmes finos que estão sendo comercializados apresentam uma eficiência entre $6 \%$ a $8 \%$, valores atualizados em 05 ago. 2011. [16].

Na Figura 3 vemos exemplos de módulos de silício cristalinos e filmes finos.
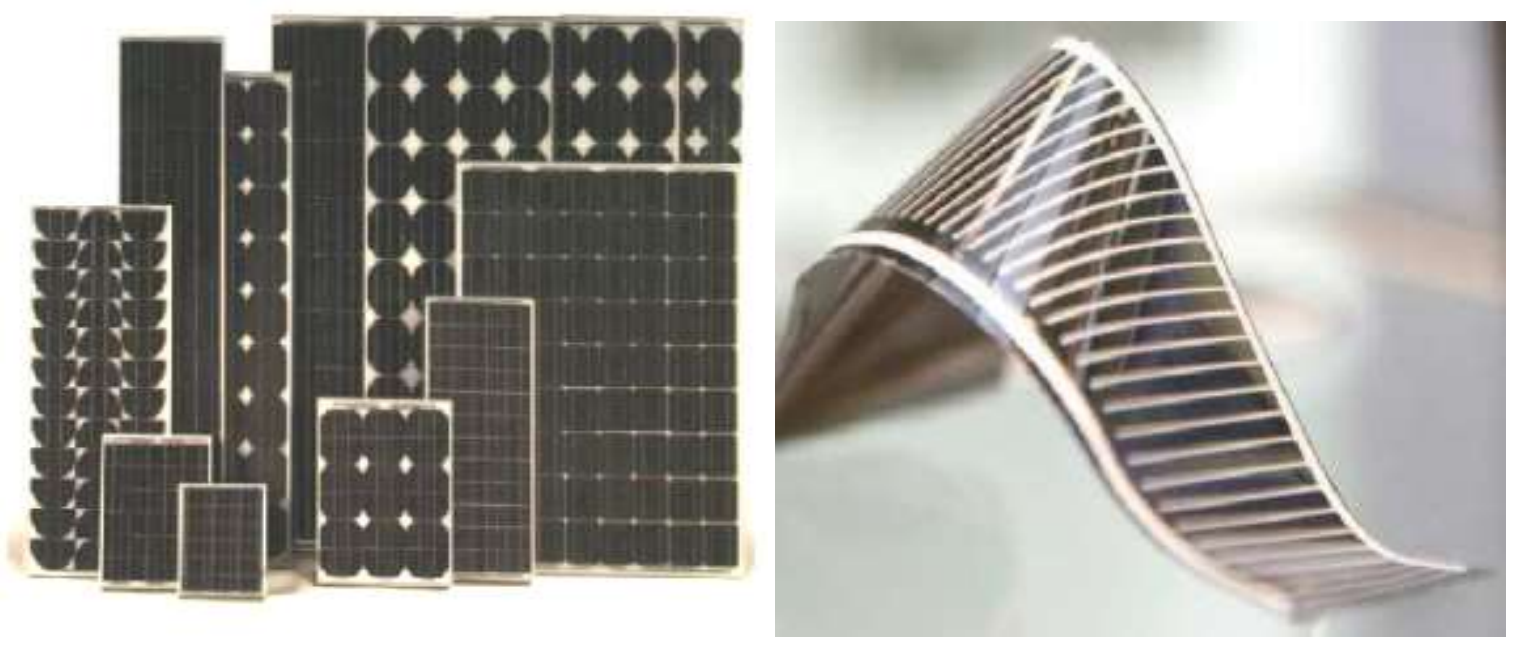

a) silício cristalino [Siemens Solar Industries]

b) filmes finos [Solarion.de]

Figura 3- Exemplo de módulos FV

Uma característica que diferencia as células de filmes finos, das células de silício cristalino é o tipo de interligação. No caso das células de silício cristalino, estas são soldadas de célula para célula, interligação externa, enquanto as células de filmes finos são interligadas monoliticamente, ou seja, as células são separadas eletricamente e interligadas em etapas estruturais, criando assim as finas ranhuras transparentes entre as células individuais, bem visíveis na Figura 3b. Estas ranhuras 
são normalmente muito finas, de forma a maximizar a produção energética, porém podem ser utilizadas como um elemento de estética e tomarem diferentes espaçamentos [8].

\subsubsection{Características das células fotovoltaicas de filmes finos}

Dentre as muitas tecnologias já disponíveis e as que estão em fase de pesquisa e desenvolvimento na área de células solares, podemos destacar as células fotovoltaicas de filmes finos (Thin-film cells). Esta tecnologia promete a diminuição do custo das células garantindo a confiabilidade, durabilidade, flexibilidade com boas características estéticas das mesmas. Utilizando uma quantidade menor de material, diminuindo o consumo de energia durante a produção das células e reduzindo a complexidade dos processos é possível garantir a produção de células de filmes finos em larga escala a um preço competitivo e acessível.

Estas células se diferenciam de outras tecnologias pela espessura das lâminas de material semicondutor utilizado em suas estruturas, em torno de $1 \mu \mathrm{m}$ (daí o nome filmes finos) o que possibilita uso de quantidades pequenas de materiais por módulo, podendo utilizar substratos de baixo custo (aço, plástico, etc) para deposição dos filmes finos (o que diminui custos e possibilita a reciclagem/reaproveitamento dos materias utilizados).

Considerando isto, módulos integralmente conectados podem ser produzidos em série, reduzindo desta forma o custo das células individuais e suas interconexões (conexões série e paralelo das células). O critério para a viabilidade do comércio de células de filmes finos ainda é baseado em condições econômicas, já que células de filmes finos utilizam materiais raros e tóxicos de difícil produção.

Mesmo com a desvantagem pela raridade de muitos materiais utilizados na produção de células de filmes finos existe a redução dos custos com módulos solares, assim como as células, também poderão ser produzidos em grandes volumes a um custo baixo devido à sistemática e padronização dos meios de produção. 
Um benefício com a produção de uma célula solar é a diminuição dos danos ao meio ambiente em seus processos produtivos. Estes danos devem ser diminuídos ou eliminados desde a extração dos minerais que serão utilizados nas células, em seu refinamento, produção e até na utilização das mesmas. A energia gasta na produção de módulos fotovoltaicos deve ser diminuída de tal forma que o retorno desta energia através do funcionamento dos módulos aconteça num espaço de tempo mais curto possível.

A tecnologia de filmes finos, sendo menos eficiente e também por estar ainda no começo de seu desenvolvimento, tem no momento um rendimento em torno de $10 \%$ para painéis solares comerciais, o que significa que se necessita de aproximadamente o dobro da área em painéis solares de filmes finos para obter a mesma energia fornecida pelos painéis de c-Si.

Estes módulos flexíveis podem ser facilmente incorporados aos projetos arquitetônicos devido as suas características de durabilidade, flexibilidade, leveza e transparência.

\subsection{TIPOS DE CÉLULAS DE FILMES FINOS}

\subsubsection{Definição}

\section{Amorfo de silício (a-Si)}

De silício amorfo (a-Si) é uma das primeiras tecnologias de filme fino desenvolvido [20]. Esta tecnologia diverge de silício cristalino pelo fato de que os átomos de silício são localizados aleatoriamente uns com os outros [21]. Esta aleatoriedade na estrutura atômica tem um grande efeito sobre as propriedades 
eletrônicas do material causando uma maior banda gap $\left(1,7 \mathrm{eV}^{2}\right)$ do que o silício cristalino $(1,1 \mathrm{eV})$. A maior banda de abertura permite a-Si absorver a parte visível do espectro solar mais fortemente do que a porção infravermelha do espectro. Existem diversas variações desta tecnologia, onde substratos podem ser de vidro ou flexível, também junção, duplos e triplos cruzamentos, e cada um tem um desempenho diferente. O material de filme fino mais conhecido é silício amorfo (a$\mathrm{Si}$ ), que está em produção há muitos anos. Os filmes são depositados pela decomposição de silano $\left(\mathrm{SiH}_{4}\right)$ em um plasma. Deposição ocorre em temperatura relativamente baixa.

Células amorfas mostram inicialmente alguma degradação de eficiência por causa do efeito Staebler-Wronski (aumento de centros de recombinação na região de carga espacial), mas foram encontradas formas de reduzir este efeito consideravelmente. Verificou-se que as células mais finas apresentam maior estabilidade.

\section{Telureto de cádmio (CdTe)}

CdTe está próximo de um material ideal fotovoltaico em relação as suas propriedades físicas. Tem um fechamento de band gap ${ }^{3}$ bom e é muito fácil de manusear na deposição de filmes finos. Células de laboratório já atingiram mais de $16 \%$ de eficiência. Uma grande desvantagem é o alto teor de cádmio que dá origem a preocupações ambientais.

${ }^{2} \mathrm{O}$ elétron-volt é uma unidade de medida de energia. Equivale a 1,602 $17733 \times 10^{-19}$ joules. Seu símbolo é eV e seu plural, elétrons-volt. Um elétron-volt é a quantidade de energia cinética ganha por um único elétron quando acelerado por uma diferença de potencial elétrico de um volt, no vácuo.

${ }^{3}$ Nos materiais semicondutores à temperatura de zero Kelvin (zero absoluto), todos os elétrons encontram-se na banda de valência. Neste estado o semicondutor tem características de um isolante, não conduz eletricidade. A medida que sua temperatura aumenta, os elétrons absorvem energia passando para a banda de condução. Esta "quantidade" de energia necessária para que o elétron efetue essa transição é chamada de gap de energia (em inglês band gap), ou banda proibida. À medida que a temperatura do semicondutor aumenta, o número de elétrons que passam para a banda de valência também aumenta, passando o semicondutor a conduzir mais eletricidade, caso seja exposto a uma ddp. 


\section{Cobre índio disseleneto (CIS)}

As células CIS, ou, se for adicionado o gálio, também CIGS, é o material mais promissor de filme fino hoje [22]. Ele alcançou a maior eficiência de todas as células de película fina.

A célula solar CIGS ou Cobre-Índio-Gálio-Selênio é o nome de um semicondutor usado em células fotoelétricas, cuja fórmula química é $\mathrm{Cu}(\operatorname{In}, \mathrm{Ga}) \mathrm{Se}_{2}$ (cobre, índio, gálio e selênio). As células CIGS são feitas com várias camadas ultrafinas de diferentes semicondutores, cada qual com diferentes gaps ${ }^{4}$ de energia.

Células solares são na verdade grandes diodos semicondutores. Quando um fóton $^{5}$ com uma energia maior que o gap de energia deste semicondutor penetra no material, um elétron é deslocado da banda de valência ${ }^{6}$ para a banda de condução ${ }^{7}$, e de modo oposto, uma lacuna ${ }^{8}$ vai da banda de condução para a banda de valência. Após a criação deste Par Elétron-Lacuna, se recombinar ou então ir à

\footnotetext{
${ }^{4}$ Nos materiais semicondutores à temperatura de zero Kelvin (zero absoluto), todos os elétrons encontram-se na banda de valência. Neste estado o semicondutor tem características de um isolante, não conduz eletricidade. A medida que sua temperatura aumenta, os elétrons absorvem energia passando para a banda de condução. Esta "quantidade" de energia necessária para que o elétron efetue essa transição é chamada de gap de energia (em inglês band gap), ou banda proibida. À medida que a temperatura do semicondutor aumenta, o número de elétrons que passam para a banda de valência também aumenta, passando o semicondutor a conduzir mais eletricidade, caso seja exposto a uma ddp.
}

${ }^{5}$ Fóton são produzidos por átomos quando um elétron de valência move-se de um orbital para outro orbital com (menos ou mais energia) negativa. Fótons também podem ser emitidos por um núcleo instável quando este decai por algum tipo de decaimento nuclear. Além disto, fótons são produzidos sempre que partículas carregadas são aceleradas. De acordo com a teoria de fótons de luz, um fóton é um pacote discreto (ou quantum), eletromagnético (ou luz) de energia. Fotões estão sempre em movimento e, no vácuo, com uma velocidade constante de luz (a velocidade da luz). O fóton é uma partícula elementar, apesar do fato de que não ter massa. Ele não pode deteriorar-se por si própria, embora a energia do fóton pode transferir (ou ser criado) após interação com outras partículas. Fótons são eletricamente neutros.

${ }^{6}$ Banda de valência é uma banda de energia formada por níveis de energia, ocupada por elétrons semilivres, que estão um pouco mais separados do núcleo que os demais.

${ }^{7}$ Banda de condução é o intervalo de energias de energia superior à da banda de valência. É nestas energias que se dá a condução elétrica.

${ }^{8}$ Lacuna ou buraco eletrônico é a ausência de um elétron numa banda de valência que, de outro modo, estaria cheia.Uma banda de valência cheia (ou quase cheia) está presente em semicondutores e isoladores elétricos. O conceito de "buraco ou lacuna" é, no fundo, uma maneira simples de análise das transições elétricas que ocorrem dentro da banda de valência. 
região de carga espacial, onde dependendo das dopagens ${ }^{9}$ dos materiais há uma diferença de potencial, causando tanto a aceleração do elétron na banda de condução como da lacuna na banda de valência. Quando os materiais estão conectados a condutores e eventuais consumidores de energia, é gerada uma corrente elétrica [23].

A Siemens lançou atualmente no mercado os primeiros produtos de uma linha de produção-piloto com eficiências acima de 10\% [24]. Há duas formas diferentes para deposição de filmes CIGS. O primeiro é com evaporação dos elementos em um substrato aquecido. Esta técnica produz as melhores eficiências de laboratório, mas apresenta dificuldades para produção industrial. O segundo processo, selenização, é mais adequado para a produção industrial. A camada de precursor de índio e de cobre é aplicada pela primeira vez por pulverização catódica. Posteriormente a selenização é realizado por recozimento.

Células solares de filmes finos já podem ser produzidas em grande escala, Cientistas da Universidade de Delaware [25], desenvolveram um novo método para a fabricação de células solares flexíveis (Figura 4).

Na Figura 4 pode-se ver longas "tiras" de células solares de filmes finos, fabricadas em um processo contínuo de alta velocidade, utilizando equipamentos que lembram muito as enormes impressoras rotativas nas quais são impressos os jornais e revistas.

As folhas contínuas de células solares são fabricadas depositando-se vários compostos em camadas sucessivas sobre uma folha de polímero de 25 centímetros de largura. Esses compostos incluem molibdênio, sulfeto de cádmio, óxido de zinco e óxido de estanho-zinco. Mas a parte mais importante é um composto chamado CIGS, cobre-indio-gálio-disseleneto. As células solares CIGS são as únicas fabricadas com a tecnologia de película fina que atingiram eficiências comparáveis às das tradicionais células solares fotovoltaicas feitas de silício.

\footnotetext{
${ }^{9}$ A dopagem no diodo é feita pela introdução de elementos dentro de cristais tetravalentes, normalmente feitos de silício e germânio [26].
} 


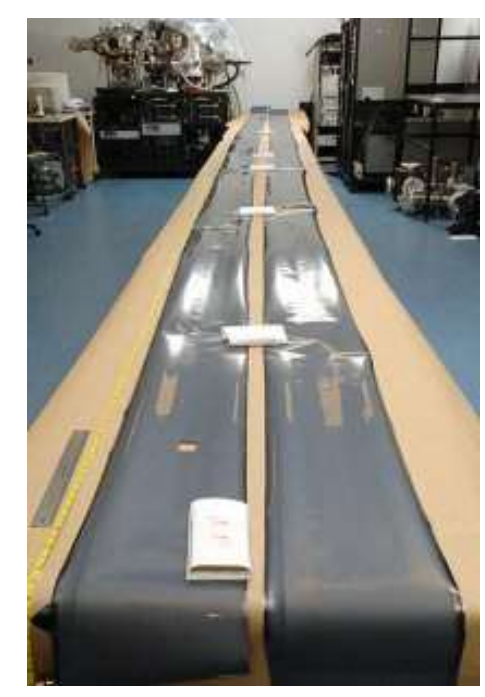

Figura 4- Foto de células solares de filmes finos

\subsubsection{Características de eficiência}

Segundo cientistas, as células solares industrialmente produzidas atingem eficiências de conversão de energia solar em eletricidade de até 10 por cento. Cientistas do Laboratório Federal Suíço de Ciências dos Materiais e Tecnologia (EMPA) trabalhando em estreita colaboração com a Companhia FLISON, sob a liderança do Dr. Ayodhya N. Tiwari estão desenvolvendo uma película fina de células solares baseadas em disseleneto de cobre, gálio e índio $\mathrm{Cu}$, (In, Ga) $\mathrm{Se}_{2}$, material semicondutor. Passando de um valor recorde anterior de $14,1 \%$ para um novo recorde de $17,6 \%$ que foi alcançada em junho de 2010 , reduzindo as perdas ópticas e eletrônicas na estrutura das células solares CIGS [27]. O recorde de eficiência de conversão foi de forma independente certificada pelo Instituto Fraunhofer de Sistemas de Energia Solar (ISE), em Freiburg, na Alemanha, que é um registro de maior eficiência de certificação independente para qualquer tipo de célula solar em filme flexível em polímero relatado até agora, segundo EMPA.

As medições fotovoltaicas realizadas sob a condição de teste padrão no ISE Freiburg confirmou a eficiência de $17,6 \%$ com $V_{\text {oc }}$ tensão com circuito aberto $=688$ $\mathrm{mV}$, Isc corrente de curto circuito $=34,8 \mathrm{~mA} / \mathrm{cm}^{2}$ e FF(Fill Factor), fator de 
preenchimento em $\%=73,6 \%$. Devido a seu baixo custo, TFPV (Filme fino fotovoltaico) estão se tornando a escolha para BIPV (Figura5).

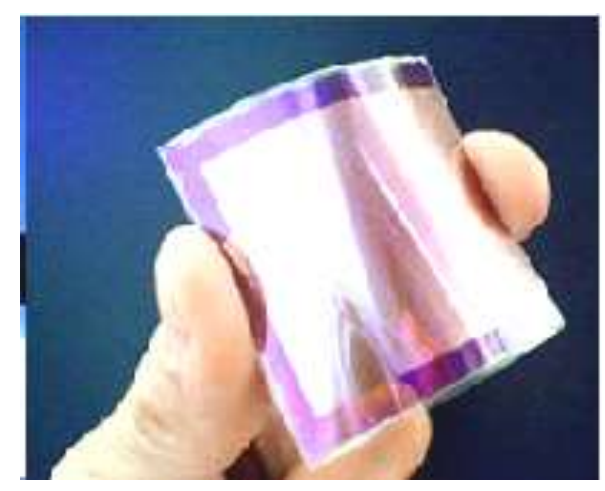

Figura 5- Foto de células solares CIGS

Os mesmos pesquisadores suíços do EMPA aumentaram a eficiência de células solares flexíveis CIGS para novo recorde mundial de 18,8\% [27]. As medições foram independentemente certificados pelo Instituto Fraunhofer para Sistemas de Energia Solar em Freiburg, Alemanha. Uma grande vantagem das novas células solares flexíveis de alto desempenho (CIGS) é o potencial para reduzir os custos de produção por meio do processamento de rolo a rolo e, ao mesmo tempo em que oferece uma eficiência muito maior do que as células existentes atualmente no mercado. Além do mais, como os módulos solares são leves e flexíveis, oferece benefícios adicionais em termo de transporte, instalação, armações para módulos, etc., ou seja, reduz significativamente o chamado "equilíbrio do sistema". 


\section{CONCEITOS SOBRE CÁLCULO DE GERAÇÃO FOTOVOLTAICA}

\subsection{INTRODUÇÃO}

Neste capítulo são abordados alguns conceitos básicos sobre cálculo da geração fotovoltaica. Todas as fórmulas citadas, neste capítulo, não serão sujeitas a extensivas demonstrações, pois o que se pretende é apenas apresentar conceitos, base de suporte ao cálculo da geração fotovoltaica.

Convém ainda referir que, nesta dissertação, o termo radiação usar-se-á num sentido genérico. Para se distinguir entre potência e energia utilizam-se definições mais precisas: irradiância para a densidade de potência numa superfície, e irradiação para a densidade de energia incidente durante um certo período de tempo, (Figura 6).

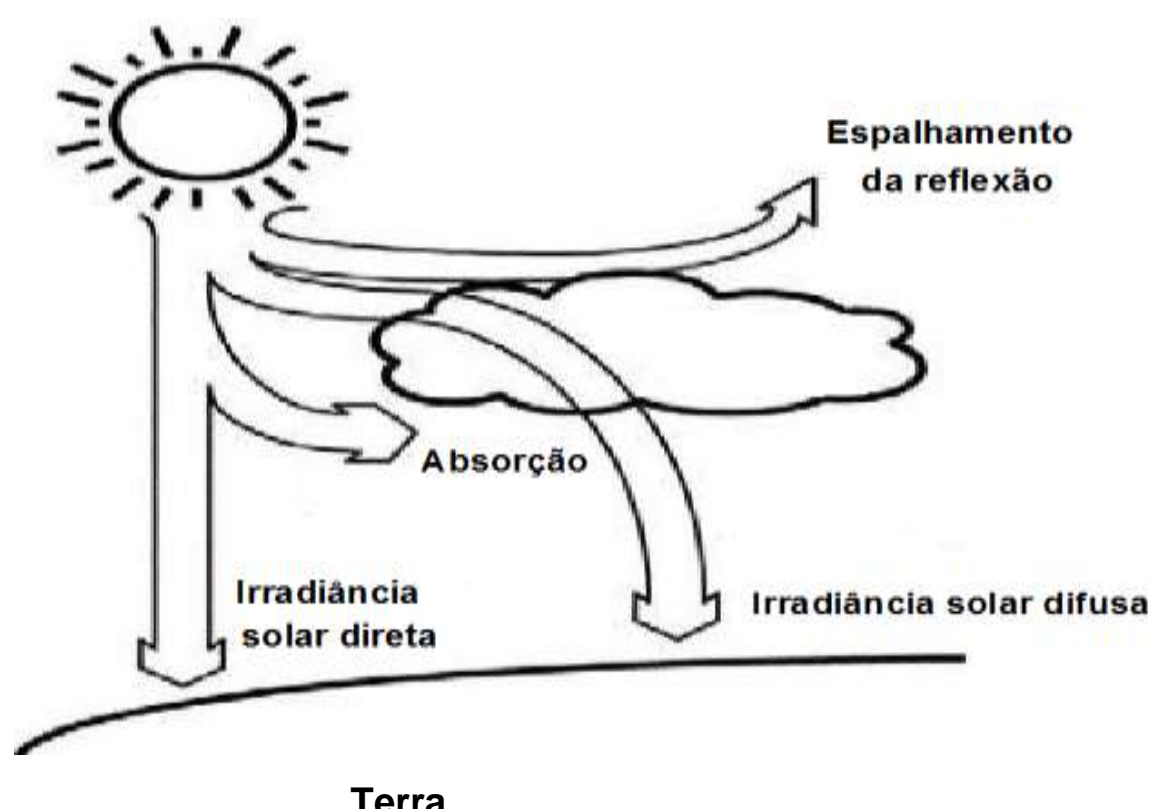

Figura 6 - Componentes da radiação solar [28]. 
A interação da radiação solar com a atmosfera da Terra e a superfície terrestre são determinadas, essencialmente, por três fatores:

- A geometria da Terra (declinação, latitude, ângulo solar);

- O terreno (elevação, inclinação e orientação da superfície, sombreamentos);

- Atenuação atmosférica (reflexão e absorção) originada por:

- Gases (moléculas do ar, ozônio, $\mathrm{CO}_{2}, \mathrm{O}_{2}$ );

- Partículas sólidas e liquidas;

- Nuvens (água condensada).

O primeiro fator determina a radiação extraterrestre disponível, levando em conta a posição do Sol. A radiação que chega a superfície terrestre é modificada pelas características do terreno. Além disso, a radiação solar que atravessa a atmosfera é atenuada por vários componentes da atmosfera, como por exemplo, gases, partículas sólidas e líquidas, nuvens (incluídos no terceiro fator) [30].

O resultado destas interações origina uma radiação solar que incide sobre um módulo FV e se divide em três componentes: a radiação direta $\left(\mathrm{H}_{\mathrm{b}}\right)$, radiação difusa $\left(H_{d}\right)$ e a radiação refletida no albedo $\left(H_{\rho}\right)$ (Figura 6). A radiação total (direta + difusa + albedo), conjunto das três componentes, que incide numa superfície é denominada radiação global $(\mathrm{H})[29]$.

A utilização das fachadas para a instalação de tecnologias solares (ângulo de inclinação $=90^{\circ}$ com relação ao plano horizontal) implica uma produção de energia menor, devido à redução significativa da irradiação.

\subsection{RADIAÇÃO SOLAR INCIDENTE NUMA SUPERFÍCIE}

No dimensionamento de qualquer sistema FV é necessário ter conhecimentos sobre a orientação da incidência dos raios solares numa superfície plana ou 
inclinada. Esse dimensionamento é determinado com base em várias relações entre diversos ângulos [30].

A declinação $(\delta)$ é o ângulo entre o plano do equador e a direção Sol-Terra e é dado pela seguinte equação:

$$
\delta=23,45 x \operatorname{sen}\left(2 \pi x \frac{284+d_{n}}{365}\right)
$$

onde:

$d_{n}$ - dia do ano, isto é o número de dias decorridos desde 1 de janeiro.

A quantidade de radiação global que incide num receptor é bastante variável. A energia solar que incide na camada atmosférica $\left(\mathrm{H}_{0}\right)$ sofre várias variações devido ao movimento aparente do Sol. Estas variações podem-se calcular teoricamente através de considerações geométricas [31]. A irradiância extraterrestre $\left(I_{0 z}\right)$ em W/m² e dada pela equação (3.2). Esta é dada em função do dia do ano [31].

$$
I_{0 z}=I_{s c} x\left[1+0,033 \times \cos \left(\frac{360 . d_{n}}{365}\right)\right]
$$

onde:

$$
\mathrm{I}_{\mathrm{sc}} \text { - constante solar }{ }^{10}
$$

Tendo em conta a posição do Sol relativamente a um plano horizontal (Figura 7), a distância zenital $\left(\theta_{z}\right)$ pode ser calculada através da equação (3.3):

$$
\theta_{z}=90^{\circ}-\gamma_{s}=\operatorname{arc} \cos (\operatorname{sen} \delta \cdot \operatorname{sen} \phi+\cos \delta \cdot \cos \omega)
$$

onde:

$\delta$ - declinação;

10 Taxa a qual é recebida a energia solar, por unidade de área, no limite exterior da atmosfera terrestre para a distância média entre a Terra e o Sol. O seu valor e de $1,367 \mathrm{~kW} / \mathrm{m}^{2}$ 
$\phi$ - latitude do local;
$\omega$ - ângulo solar ${ }^{11} ;$
$\gamma_{\mathrm{s}}$ - elevação solar ${ }^{12}$.

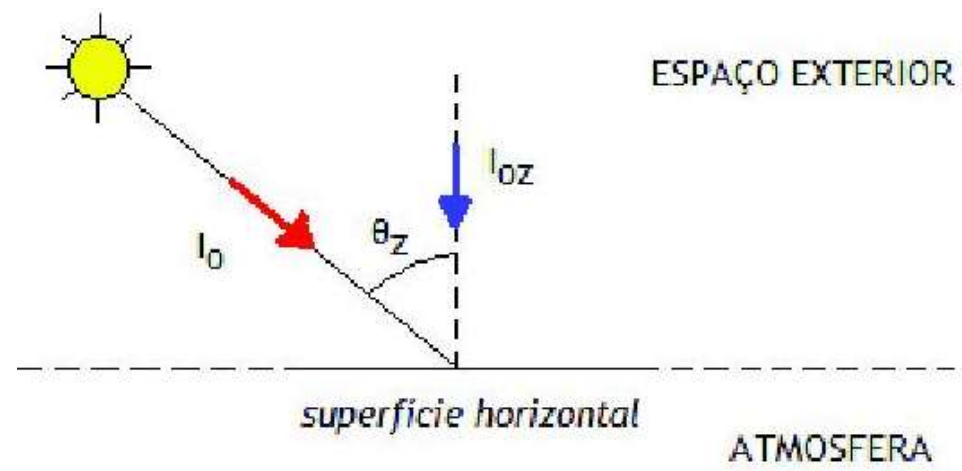

Figura 7- Irradiância extraterrestre sobre uma superfície horizontal [35].

Posto isto, a densidade de potência extraterrestre $\left(\mathrm{W} / \mathrm{m}^{2}\right)$ incidente numa superfície horizontal $\left(I_{0}\right)$ é dada em função do dia do ano, da latitude do local, da hora do dia e do ângulo da declinação solar equação (3.4):

$$
\mathrm{I}_{0}=\mathrm{I}_{\mathrm{sc}} \mathrm{x}\left[1+0,033 x \cos \left(\frac{360 \cdot d_{n}}{365}\right)\right] x(\operatorname{sen} \delta \cdot \operatorname{sen} \phi+\cos \delta \cdot \cos \omega)
$$

$\mathrm{O}$ azimute $\operatorname{solar}^{13}$ ( $\left.\Psi \mathrm{s}\right)$ (Figura 8), não é mais que o ângulo formado entre a direção Sul e a projeção da linha Sol-Terra sobre a horizontal, pode ser calculado através da equação (3.5):

${ }^{11}$ Deslocamento angular $(\omega)$ do Sol a leste ou a oeste em relação ao meridiano local, devido à rotação da terra. O período da manha e negativo e do tarde positivo. Cada hora corresponde ao deslocamento de $15^{\circ}$ [32].

12 Ângulo entre os raios solares e sua projeção no plano horizontal.

${ }^{13}$ Considera-se o azimute solar positivo para Oeste e negativo para Este. 


$$
\Psi_{\mathrm{S}}=\arccos \left(\frac{\operatorname{sen} \gamma \mathrm{s} \times \operatorname{sen} \phi-\operatorname{sen} \delta}{\cos \gamma \mathrm{s} \cdot \cos \phi}\right)
$$

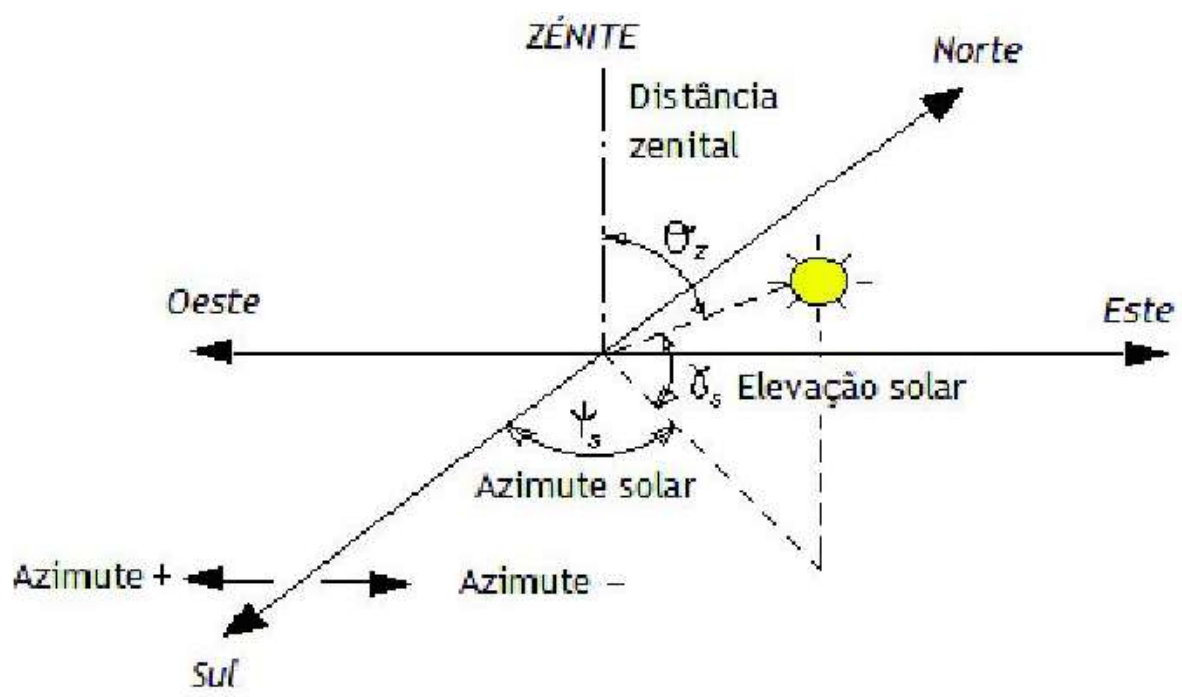

Figura 8- Posicionamento do Sol relativamente à superfície horizontal [33].

A irradiação extraterrestre média diária numa superfície horizontal $\left(\mathrm{H}_{0}\right)$ é determinada pela integração da equação (3.4), desde o nascer ao pôr do sol [32].

$$
\begin{aligned}
& H_{0}=\frac{24}{\pi} \times I_{s c} \times\left[1+0,033 \times \cos \left(\frac{360 \cdot d_{n}}{365}\right)\right] \times\left(\left|\omega_{s}\right| \cdot \operatorname{sen} \delta \cdot \operatorname{sen} \phi+\right. \\
& \left.\cos \delta \cdot \operatorname{sen}\left|\omega_{s}\right|\right)
\end{aligned}
$$

onde:

$$
\begin{aligned}
& \omega_{\mathrm{S}} \text { - ângulo de saída do Sol e é dado pela equação } \\
& \omega_{\mathrm{S}}=-\omega_{\mathrm{p}}=-\operatorname{arc} \cos (-\operatorname{tg} \delta \times \operatorname{tg} \phi)
\end{aligned}
$$


onde:

$$
\omega_{p}=\text { ângulo de pôr do sol }
$$

Para superfícies inclinadas e orientadas segundo um determinado ângulo de azimute $(\alpha)$, as relações geométricas entre os ângulos anteriormente definidos, permitem calcular o ângulo de incidência solar $\left(\theta_{s}\right)$ equação (3.8), sobre uma superfície (Figura 9) [32].

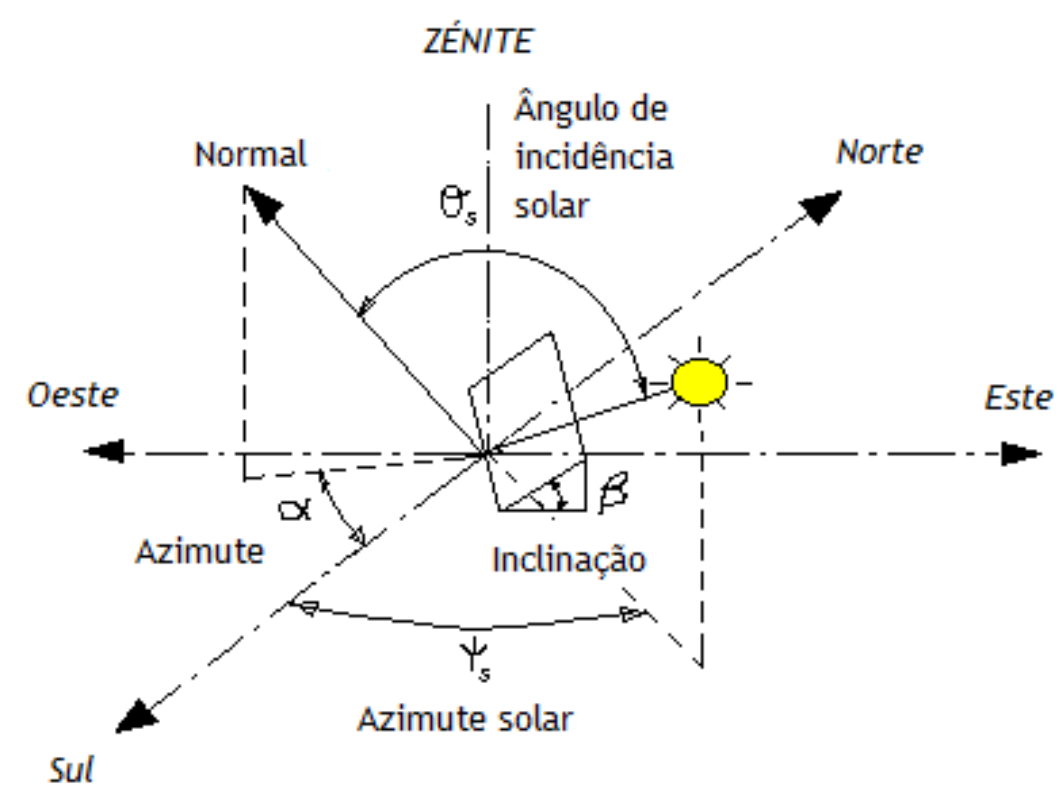

Figura 9- Ângulo de incidência numa superfície inclinada e orientada [35].

$\cos \theta_{\mathrm{s}}=\operatorname{sen} \delta \cdot \operatorname{sen} \phi \cos \beta-\operatorname{sen} \delta \cos \phi \operatorname{sen} \beta \cdot \cos \alpha+\cos \delta \cdot \cos \phi \cdot \cos \beta$. $\cos \omega+\cos \delta \cdot \operatorname{sen} \phi \cdot \operatorname{sen} \beta \cdot \cos \alpha \cdot \cos \omega+\cos \delta \cdot \operatorname{sen} \beta \cdot \operatorname{sen} \alpha \cdot \operatorname{sen} \omega$ (3.8)

onde:

$\left(\theta_{\mathrm{s}}\right)$ = ângulo de incidência solar sobre uma superfície;

$(\delta)$ = declinação; 

$(\phi)=$ latitude do local;
$(\beta)$ = inclinação dos módulos;
$(\alpha)$ ângulo de azimute;
$(\omega)$ a ângulo do deslocamento do sol.

Uma vez determinada a irradiação extraterrestre diária no plano horizontal, através da equação (3.6), pode-se determinar as componentes da radiação solar, direta e difusa. Para tal, é necessário calcular o índice de atenuação $\left(\mathrm{K}_{T}\right)$, pela equação (3.9), que representa o efeito de atenuação da atmosfera terrestre [33]:

$$
\mathrm{K}_{\mathrm{T}}=\mathrm{H} / \mathrm{H}_{0}
$$

onde:

$$
\begin{aligned}
& \text { H - irradiação global (medida ou estimada); } \\
& H_{0} \text { - irradiação extraterrestre calculada pela equação (3.6). }
\end{aligned}
$$

O valor da irradiação global utilizado pode ser medido numa estação próxima do local ou então estimado com base no índice de insolação do local.

Uma vez determinado o índice de atenuação, pode-se estimar a irradiação difusa em função da irradiação global $(\mathrm{H})$, aplicando para tal os modelos de regressão existentes [modelo de Collares-Pereira [34] ou modelo de Ruth e Chant].

Determinada a irradiação difusa, a irradiação direta diária $\left(\mathrm{H}_{\mathrm{b}}\right)$ é calculada pela diferença entre a irradiação global e a irradiação difusa, equação (3.10): 


$$
\mathrm{H}_{\mathrm{b}}=\mathrm{H}-\mathrm{H}_{\mathrm{d}}
$$

onde:

$$
H_{d} \text { - irradiação difusa }=H \times 0,99 \text { se } K_{T} \geq 0,17
$$

A relação entre a irradiação direta sobre uma superfície inclinada (dada pelo ângulo $\theta_{\mathrm{s}}$ ) e a irradiação sobre o plano horizontal (dada pelo angulo $\theta_{z}$ ) pode ser determinada pela equação (3.11) [32].

$$
\mathrm{R}_{\mathrm{b}}=\frac{\int_{\omega_{\mathrm{s}}}^{\omega_{\mathrm{p}}} \mathrm{I}_{\mathrm{O}_{\mathrm{z}}} \cos \theta_{\mathrm{s}}}{\int_{\omega_{\mathrm{s}} \mathrm{p}}^{\omega_{\mathrm{p}}} \mathrm{I}_{\mathrm{z}_{\mathrm{z}}} \cos \theta_{\mathrm{z}}}
$$

A irradiação total diária $\left(H_{t}\right)$ incidente em superfícies inclinadas é calculada somando as três componentes da radiação (direta, difusa e refletida pelo solo), equação (3.12) [32].

$$
H_{t}=H_{b} \times R_{b}+H_{d} \times\left(\frac{1+\cos \beta}{2}\right)+H \times\left(\frac{1-\cos \beta}{2}\right) \times \rho
$$

onde:

$\rho$ - representa a refletividade do solo.

Para determinadas situações é interessante estimar a radiação solar horária. Para estas situações recorre-se a modelos que permitam uma estimativa horária a partir de informação diária, ou seja, a partir dos valores médios estimados para a radiação diária, estimam-se os valores da radiação horária. Tal como no processo de estimação da radiação difusa a partir da radiação global, este também não é um processo exato. Estudos estatísticos da distribuição temporal da radiação em superfícies horizontais ao longo do dia, usando dados recolhidos em diversas estações meteorológicas da média mensal, levaram a construção de gráficos para determinar o parâmetro $\Upsilon_{t}$, que representa o quociente entre a radiação global horária e diária, dado pela equação (3.13) [32]. 


$$
r t=\frac{h}{H}=\frac{\pi}{24}(a+b \cos \omega) \frac{\cos \omega-\cos \omega_{s}}{\operatorname{sen} \omega_{s}-\omega_{s} \cos \omega_{s}}
$$

Os coeficientes a e b, presentes na equação (3.13) são dados pelas respectivas equações:

$$
\begin{aligned}
& a=0,409+0,5016 \operatorname{sen}\left(\omega_{s}-\pi / 3\right) \\
& b=0,6609-0,4767 \operatorname{sen}\left(\omega_{s}-\pi / 3\right)
\end{aligned}
$$

Nas equações anteriores os ângulos horários são em radianos para as horas em questão. Do mesmo modo, pode-se estimar a radiação difusa horária, na horizontal, através dos valores diários obtidos, a partir do parâmetro $\Upsilon_{d}$, dado pela equação (3.16) [32].

$$
\Upsilon_{\mathrm{d}}=\frac{\mathrm{h}_{\mathrm{d}}}{\mathrm{H}_{\mathrm{d}}}=\frac{\pi}{24} \frac{\cos \omega-\cos \omega_{\mathrm{s}}}{\operatorname{sen} \omega_{\mathrm{s}}-\omega_{\mathrm{s}} \cos \omega_{\mathrm{s}}}
$$

Tal como para a radiação direta diária, a estimativa da radiação direta horária na horizontal determina-se pela equação (3.17).

$$
h_{b}=h-h_{d}
$$

O cálculo da radiação total horária e semelhante ao da radiação diária anteriormente descrita. Desta forma a equação (3.18) permite obter uma estimativa da radiação total horária incidente numa superfície [32].

$$
h_{t}=h_{b} \times R_{b}+h_{d}\left(\frac{1+\cos \beta}{2}\right)+h \times\left(\frac{1-\cos \beta}{2}\right) \times \rho
$$


Como regra geral, a inclinação ótima com relação à horizontal para a incidência solar máxima em regime anual é dada pela latitude local. A orientação ideal é a de uma superfície voltada para o equador (norte geográfico para instalações no hemisfério sul) [36].

\subsection{SOMBREAMENTO}

Ao redor dos módulos FV podem existir árvores, paredes, outros módulos e edifícios, que em determinadas ocasiões, principalmente quando os módulos se integram na arquitetura dos edifícios, podem originar sombras sobre os módulos, provocando desta forma uma redução da sua capacidade de produção. Estas situações devem ser cuidadosamente consideradas no projeto do sistema FV [31].

As equações (3.3) e (3.5), permitem representar as trajetórias do Sol em função da elevação $\left(\gamma_{s}\right)$ e do azimute solar $\left(\Psi_{s}\right)$. O efeito de sombreamento na geração de energia dos módulos FV deve ser considerado no projeto, e nestas situações considera-se que a componente direta da radiação solar é nula [31].

Quando uma superfície não esta diretamente exposta aos raios solares significa que se encontra na sombra. Nestas situações de sombreamento, há alguns aspectos que se devem considerar. Existem, essencialmente, dois tipos de sombreamentos, designados por sombra de uma colina (hill shade) e projeção de sombras (cast shade). O hill shade acontece quando a superfície se encontra fora da linha projetada na horizontal pela fonte de luz, ou seja, quando o ângulo de incidência definido pela equação (3.8) é superior a $90^{\circ}$. A determinação de cast shade é mais complexa, é ocorre para superfícies que apesar de estarem orientadas para a fonte de luz, é o seu ângulo de incidência ser inferior a $90^{\circ}$, estão sujeitas a sombreamentos devido a projeção de sombras provocadas por outros objetos (edifícios, árvores, torres, entre outros) ou ate pela própria topografia do terreno (Figura 10) [35]. 
Como foi mencionado anteriormente, as superfícies que estão na sombra apenas recebem energia proveniente da radiação difusa, que é normalmente duas vezes inferior a energia proveniente da radiação direta. Assim sendo, a determinação das sombras (hill e cast shade) é um importante passo no processo de cálculo de estimativa da geração fotovoltaica em ambiente urbano.

$\begin{array}{cccc}\text { Exposto ao sol } & \text { Parcialmente } & \text { Sombra de } & \text { Projeção de } \\ \text { exposed to the Sun } & \text { partially insolated } & \text { uma colina } & \text { sombras } \\ \text { hill shade } & \text { cast shade }\end{array}$

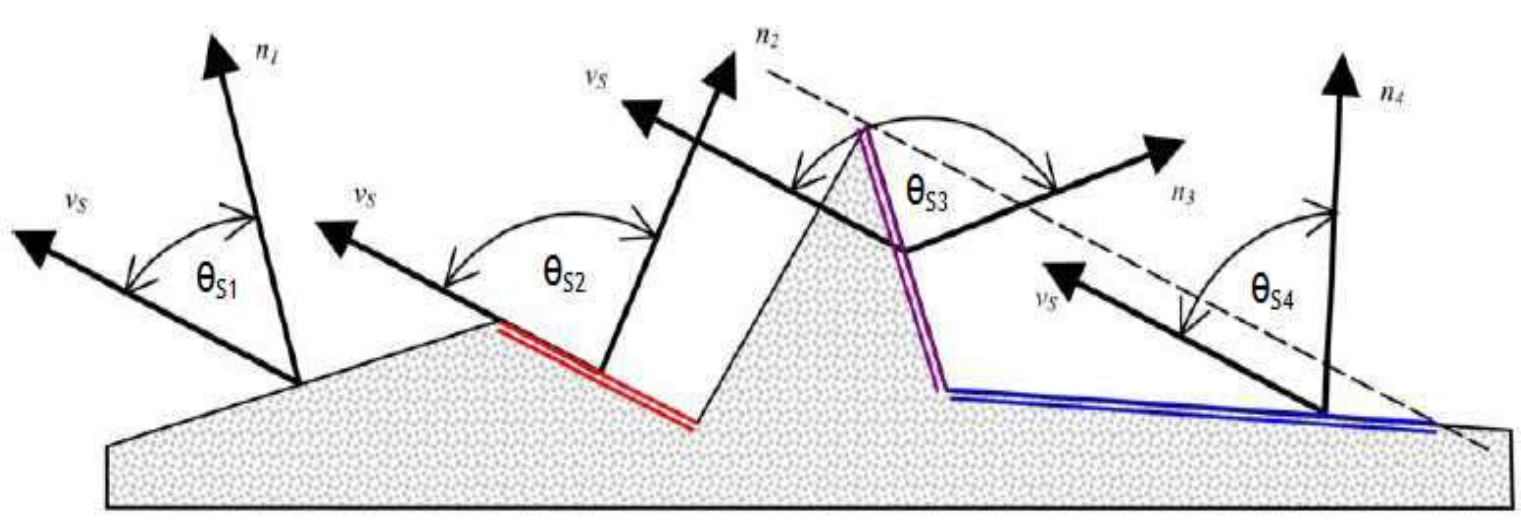

Figura 10 - Ângulos de incidência solar: sombra de uma colina (hill shade) e projeção de sombras(cast shade) [35].

O primeiro passo, na determinação de sombreamentos cast shade, é encontrar o ponto mais alto do obstáculo que projeta o sombreamento. Este é o ponto onde ocorre em primeiro lugar o hill shade. Após encontrar esse ponto, percorre-se todo o espaço ao encontro do ângulo de azimute dos raios solares. Em cada ponto susceptível de análise é determinada a distância zenital entre ele próprio e o ponto mais alto do obstáculo (z). Se a distância zenital determinada for inferior à distância zenital dada pela posição do Sol $\left(\theta_{z}\right)$, então isso significa que a superfície esta sujeita a cast shade. Por outro lado, se for superior $\left(z>\theta_{z}\right)$ então a superfície encontra-se exposta à radiação solar (Figura 11) [35]. 


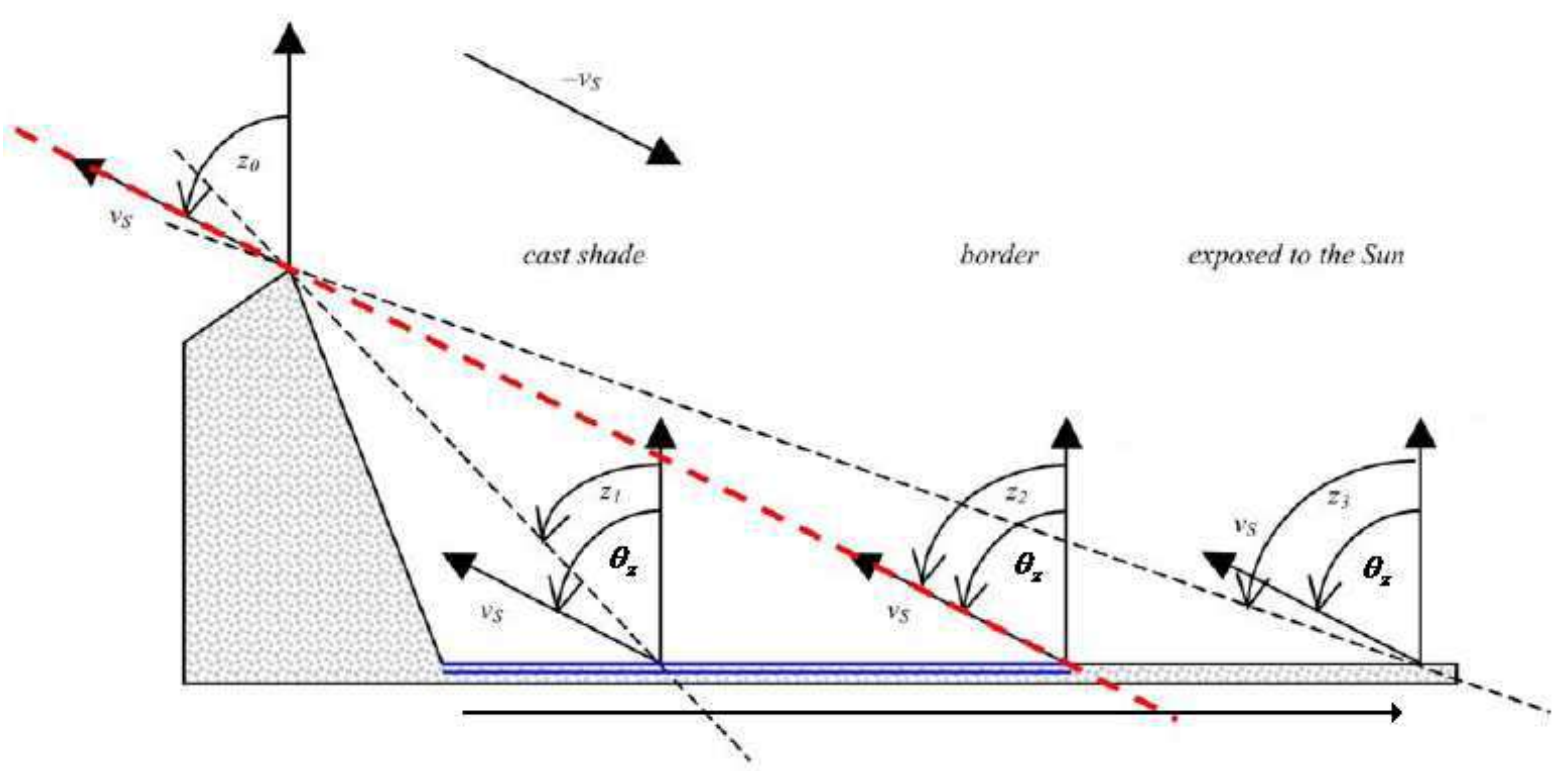

Figura 11 - Determinação da projeção de sombras (cast shade) [35]

O ponto mais alto do objeto que provoca a existência de sombreamentos por cast shade, é determinado tendo em conta o ângulo de elevação do objeto, $\gamma$. Este é calculado com base na sua altura $\left(h_{2}\right)$, na altura da superfície onde se pretende determinar se existe ou não sombreamento $\left(h_{1}\right)$ e na distância entre ambos (d), equação (3.19), (Figura 12) :

$$
\operatorname{tg} \gamma=\left(\frac{\mathrm{h}_{2}-\mathrm{h}_{1}}{\mathrm{~d}}\right) \rightarrow \gamma=\operatorname{arctg}\left(\frac{\mathrm{h}_{2}-\mathrm{h}_{1}}{\mathrm{~d}}\right)=\operatorname{arctg}\left(\frac{\Delta \mathrm{h}}{\mathrm{d}}\right)
$$




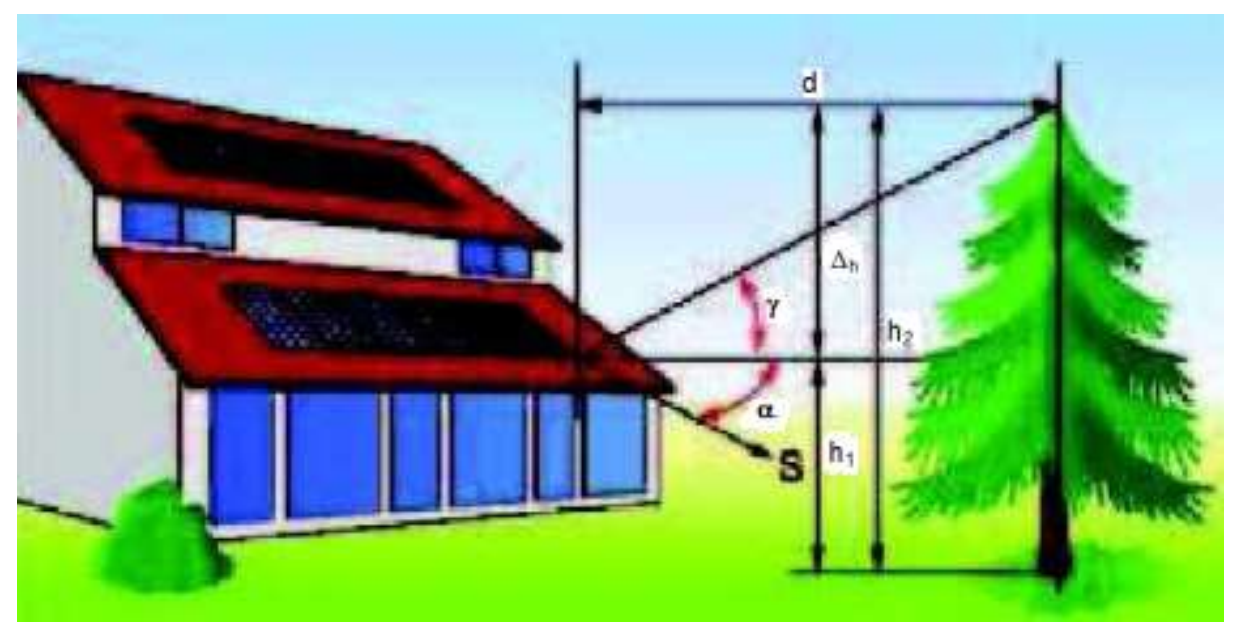

Figura 12 - Determinação do ângulo de elevação de um objeto.

\subsection{ESTIMATIVA DA GERAÇÃO FOTOVOLTAICA}

Uma vez determinada à radiação total incidente sobre uma superfície de um sistema fotovoltaico genérico, procede-se ao cálculo da geração fotovoltaica. Este pode ser efetuado tendo em conta as características das células FV utilizadas nos módulos, principalmente, a sua eficiência. A expressão que permite estimar a produção em função da sua área e da eficiência dos módulos é a seguinte, equação (3.20) [36]:

$$
E_{F V}(W h)=\overline{\mathbf{H}}_{t}\left(W h / m^{2}\right) \times \eta_{F V} \times A\left(m^{2}\right) \times \eta_{M P P T}
$$

De acordo com a equação (3.20), a geração anual depende, além da radiação total média incidente sobre o plano do modulo $\mathrm{FV}(\overline{\mathbf{H}} \mathrm{t})$, das características dos módulos que serão utilizados no sistema, principalmente a área $(A)$ e a sua eficiência $(\eta F V) . O$ inversor c.c./c.a é o coração do sistema FV conectado a rede, e têm por finalidade efetuar a conversão da potência c.c., fornecida pelo gerador FV, em potência c.a., que será injetada diretamente na rede elétrica. Além disso, esse disposi- 
tivo tem por função efetuar o seguimento do ponto de máxima potência do gerador FV, designados por MPPT ( Seguidor do Ponto de Máxima Potência ), fazendo com que sempre esteja disponível na entrada do inversor, a máxima potência que o gerador pode suprir em determinado momento [37]. A eficiência do inversor e do MPPT, ( $\left.\eta_{\text {MPPT }}\right)$, também deve ser considerada no cálculo da geração, apesar de apresentarem valores elevados (»90\%).

Assim, a eficiência de todo o sistema, inversor e MPPT, contribui para a maior ou menor geração de energia FV.

\subsection{MODELAGEM DE PREVISÃO DA GERAÇÃO FOTOVOLTAICA EM AMBIENTE URBANO}

Esta metodologia estima o potencial fotovoltaico de forma massiva para zonas urbanas, sendo utilizo para tal, modelos de análise espacial e tridimensional, suportados pelo Sistema de Informação Geográfica - SIG. O programa que se utilizou, a seguir para modelar a geração fotovoltaica em ambiente urbano foi o ArcGIS. O ArcGIS é um conjunto de programas informáticos que constitui um SIG, permitindo diversas funcionalidades entre as quais a análise espacial, manipulação de dados e mapeamento. Um SIG é um sistema de manipulação, análise e visualização de informação geográfica, este organiza toda a informação geográfica em diversas camadas (layers) e tabelas (Figura 13). 


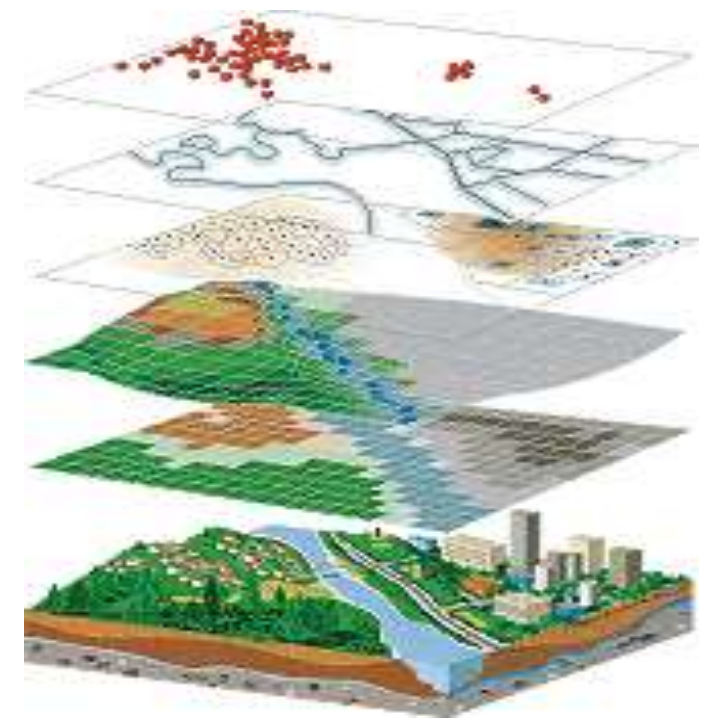

Figura 13 - Integração de vários tipos de camadas (layers) num SIG (38).

\subsubsection{Metodologia de Previsão}

A radiação solar incidente na superfície terrestre resulta de interações complexas de energia entre a atmosfera e a superfície. Numa escala global, os diferentes gradientes da radiação são causados devido à rotação e translação da terra em torno do Sol. Por outro lado, numa escala local/regional o relevo do terreno é o principal fator da distribuição da radiação. A variação em termos de elevação, da inclinação e orientação do terreno, bem como as sombras por este provocada levam a esta variabilidade da radiação. Como se pretende desenvolver um método que estime o potencial fotovoltaico integrado em edifícios numa dada região, nada melhor que ter informação dessa região com dados importantes como e o caso da localização e elevação de cada ponto do terreno. Esta informação esta contida nos denominados modelos digitais de terreno, (Digital Terrain Models - DTM). Os DTM não são mais que métodos de transformação de dados sobre a variação continua do relevo da superfície terrestre, usando curvas de nível ou representações gráficas tridimensionais, modelos digitais de elevação, (Digital Elevation Models - DEM), 
informação a qual é possível sobrepor outro tipo de informação, como por exemplo estradas, recursos hídricos é também edifícios. A criação de edifícios sobre os DTM depende dos dados disponíveis sobre a localização real dos edifícios numa dada zona. Caso se tenha os pontos associados a cada edifício bem como dados sobre a sua altitude e área, pode-se construir um mapeamento próximo da realidade da zona em questão (Figura 14).

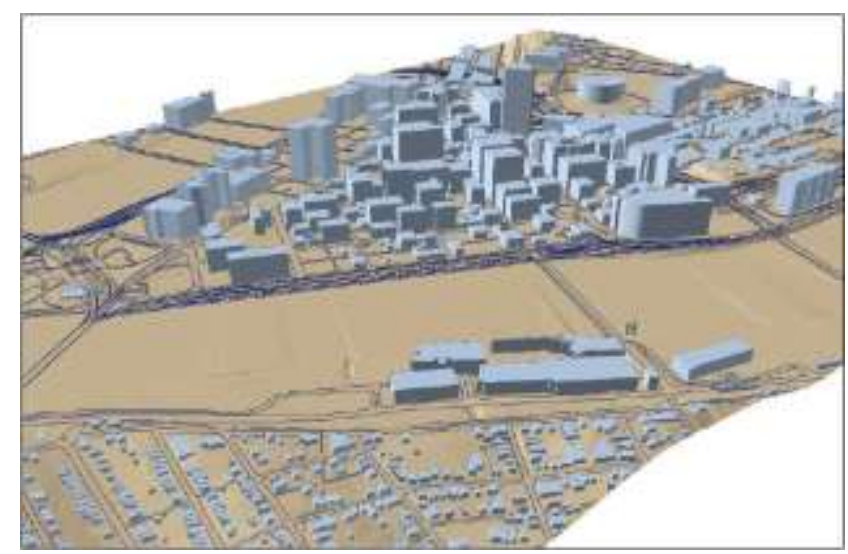

Figura 14 - Representação da criação de edifícios sobre um DTM [39].

3.5.1.1 Manipulação de camadas (layers) para cálculo da radiação solar

Para melhor compreender os passos necessários para a aplicação da metodologia proposta, o seguinte fluxograma, (Figura 15), ilustra o encadeamento de processos que devem ser tomados na manipulação das diferentes camadas de um SIG, e que levam ao cálculo da radiação solar. 


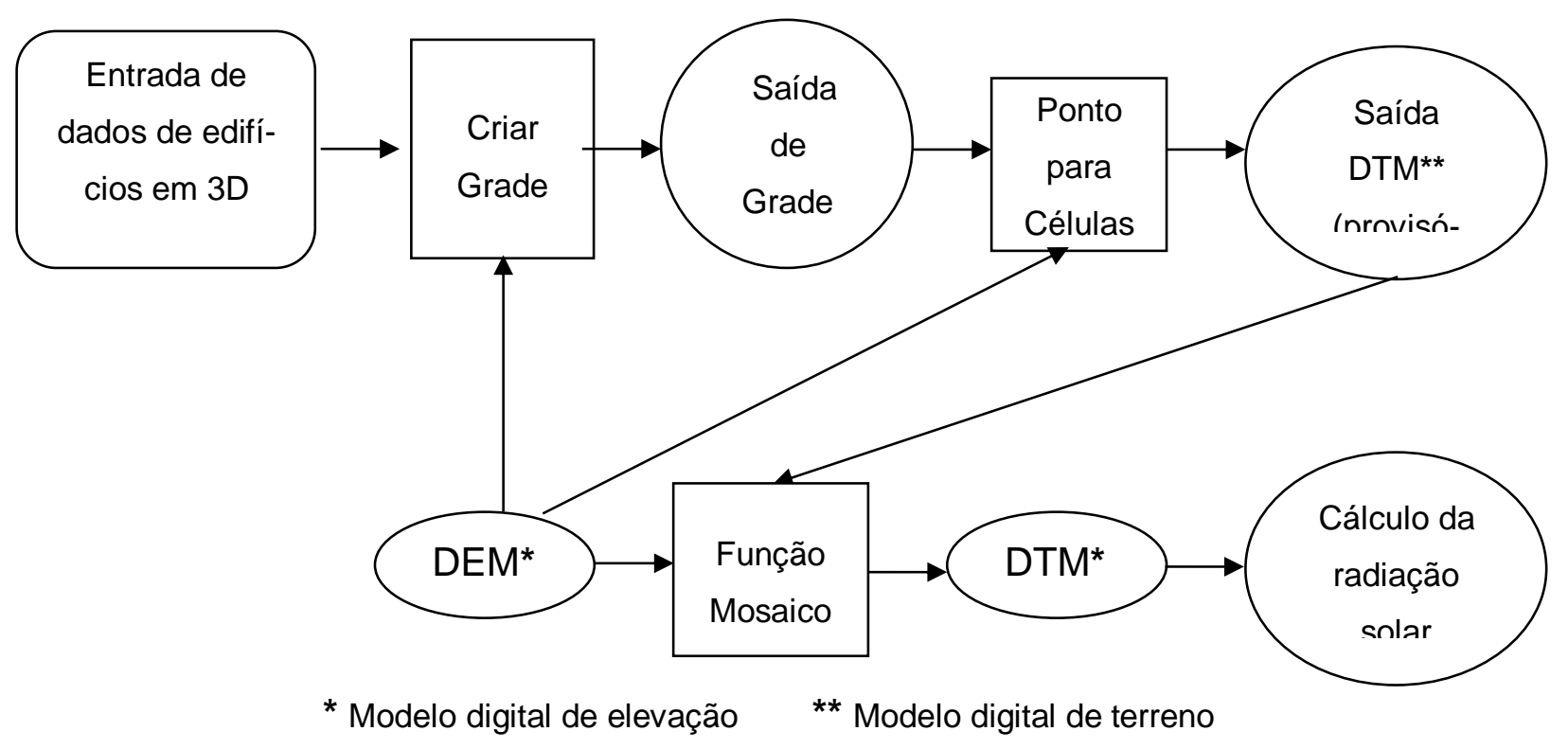

Figura 15 - Fluxograma do modelo de cálculo de geração fotovoltaica em ambiente urbano.

\subsection{Criação de grade (lattice)}

Dentro deste bloco é necessário efetuar um conjunto de manipulações de camadas, de forma a obter uma representação final onde se possa representar toda a informação geográfica relevante, estando assim pronto a aplicar operadores analíticos de geo-processamento que permitam calcular a radiação solar.

Tendo a região pretendida para estimar a geração fotovoltaica, o passo seguinte será representar essa mesma zona através de uma matriz de pontos igualmente espaçados em uma malha de pontos (mesh points) no referencial XYZ (Figura 16). Cada um desses pontos terá o valor da coordenada $Z$, referenciados a uma base comum, como por exemplo, em relação ao nível do mar. 


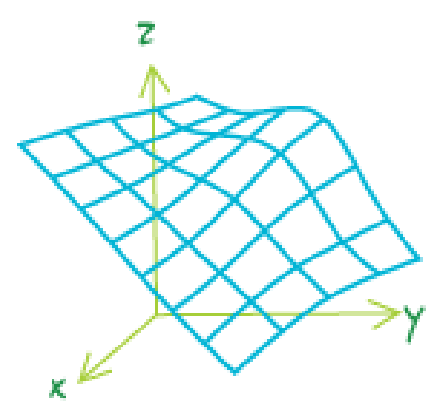

Figura 16 - Representação de uma superfície com malha de pontos (mesh points) e grade (lattice) [40].

Os pontos da coordenada $Z$ são dados pela informação contida no modelo digital de elevação (DEM) da zona a analisar.

Tendo esta representação, o próximo passo será converter esta superfície de polígonos numa superfície com células (rasters), bastante útil para tratamento de dados.

Neste momento, passa-se a ter uma representação, bidimensional, mas agora com a representação das células, que será extremamente útil para depois se proceder ao cálculo da radiação solar. Uma representação em células, muito sucintamente, é a representação de uma área geográfica dividida por varias células discretas (quadradas ou retangulares) dispostas numa rede. A cada célula pode ser atribuído um valor que permite obter informações sobre as características da sua localização. Na Figura 17 pode-se observar de que forma vários polígonos passam a ser representados numa imagem composta de células. 

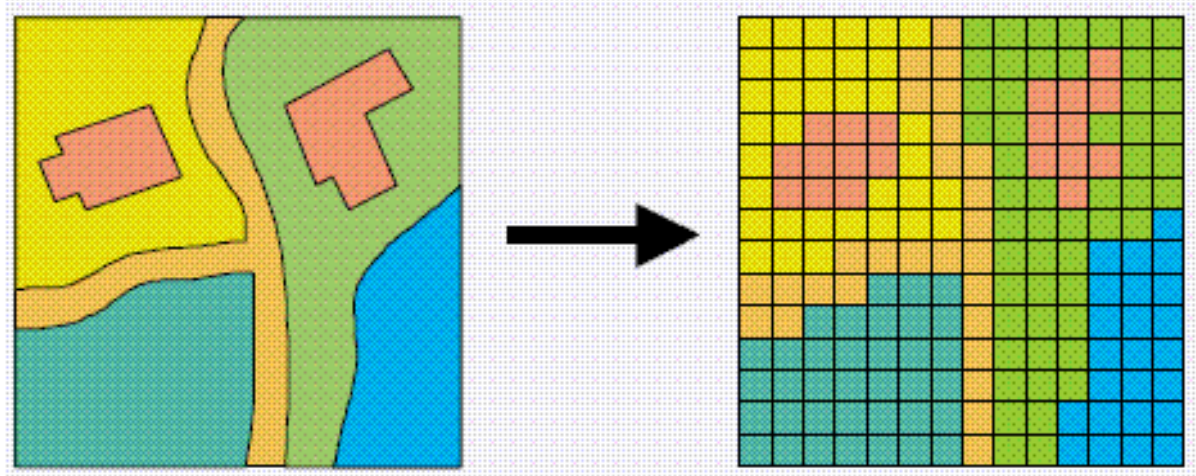

Figura 17 - Exemplo de uma representação em células (Raster).

As representações em células têm pelo menos dois pontos de grande interesse: primeiro porque permitem representar toda a informação geográfica (características geográficas, imagens, superfícies), e segundo porque tem um vasto conjunto de operadores analíticos de geo-processamento. Este tratamento de representações anteriormente descrito é efetuado no bloco "Criar Grade (lattice)" do fluxograma da Figura 15.

Esta representação, designada por grade (lattice), passará a ter valores importantes para a manipulação de dados e para a construção de camadas (layer) em três dimensões. Para além de conter os pontos da coordenada $Z$, os designados z-values, importantes na representação 3D, também contém os pontos das respectivas coordenadas xy. Assim, cada um dos pontos da grade (lattice) contém a informação necessária para representar e visualizar uma zona/região geográfica em três dimensões. Através da conjugação da informação destas representações é possível construir uma representação de melhor controle e manipulação de dados. Neste ponto, tem-se uma representação onde a superfície total esta subdividida por diversas células que contem informação útil para o cálculo da radiação solar. 


\subsection{Função mosaico (mosaic)}

$\mathrm{Na}$ eventualidade de existirem várias representações em células que representam áreas de uma zona geográfica, é necessário conjugar essas representações numa só. Para tal, o bloco mosaico do fluxograma (Figura 15) irá converter todos os conjuntos de representações de células (caso existam várias representações de áreas diferentes da mesma região de análise) numa única representação, conjugando-as sem alteração dos dados (Figura 18).

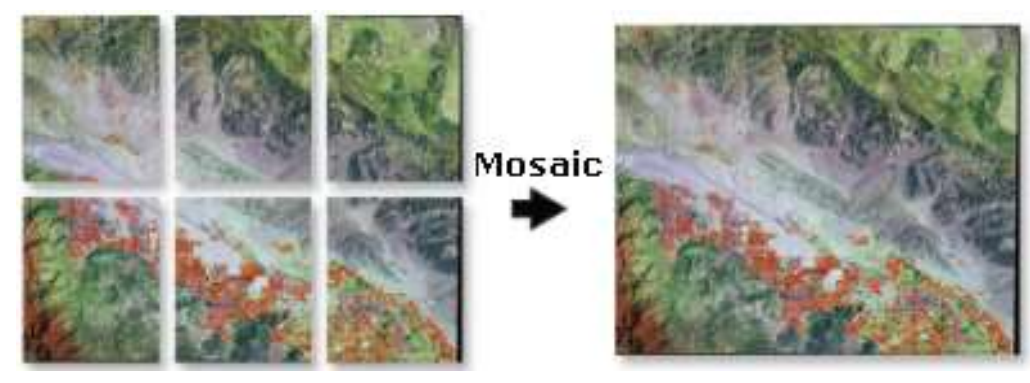

Figura 18 - Ilustração da função Mosaic do programa ArcGIS.

\subsubsection{Análises tridimensional de sombreamentos}

A representação em células é bastante importante neste modelo, pois a radiação solar incidente em cada ponto é diferente, uma vez que esta depende, entre outros fatores, da inclinação e da orientação da superfície. Como se pretende obter uma estimativa da geração fotovoltaica durante um determinado período de tempo, nada melhor que realizar esse cálculo hora a hora é verificar a radiação solar em cada uma das diferentes células associadas a cada local do edifício.

Contudo, devido à envolvência urbana, a análise de sombreamentos é uma questão fundamental e complexa. Para uma determinada posição solar, podem existir zonas do edifício que ficam invisíveis devido ao sombreamento provocado por outros obstáculos. Este fenômeno, anteriormente designado de projeção de sombra (cast shade), requer uma análise cuidadosa. Para cada uma das células é 
necessário proceder a mesma análise descrita no item 3.3, relativo a determinação dos pontos visíveis ou invisíveis. Assim, compara-se o ângulo entre a normal da célula sujeita a análise e o ponto mais alto do obstáculo (z), com o ângulo de incidência dado pela posição solar $\left(\theta_{s}\right)$ (Figura 19). Para além disso, é também necessário verificar em cada momento o ângulo de incidência entre a linha Sol-Terra e a normal a célula em análise, é caso seja superior a $90^{\circ}$ a célula encontra-se a sombra de uma colina ( $h i l l$ shade).

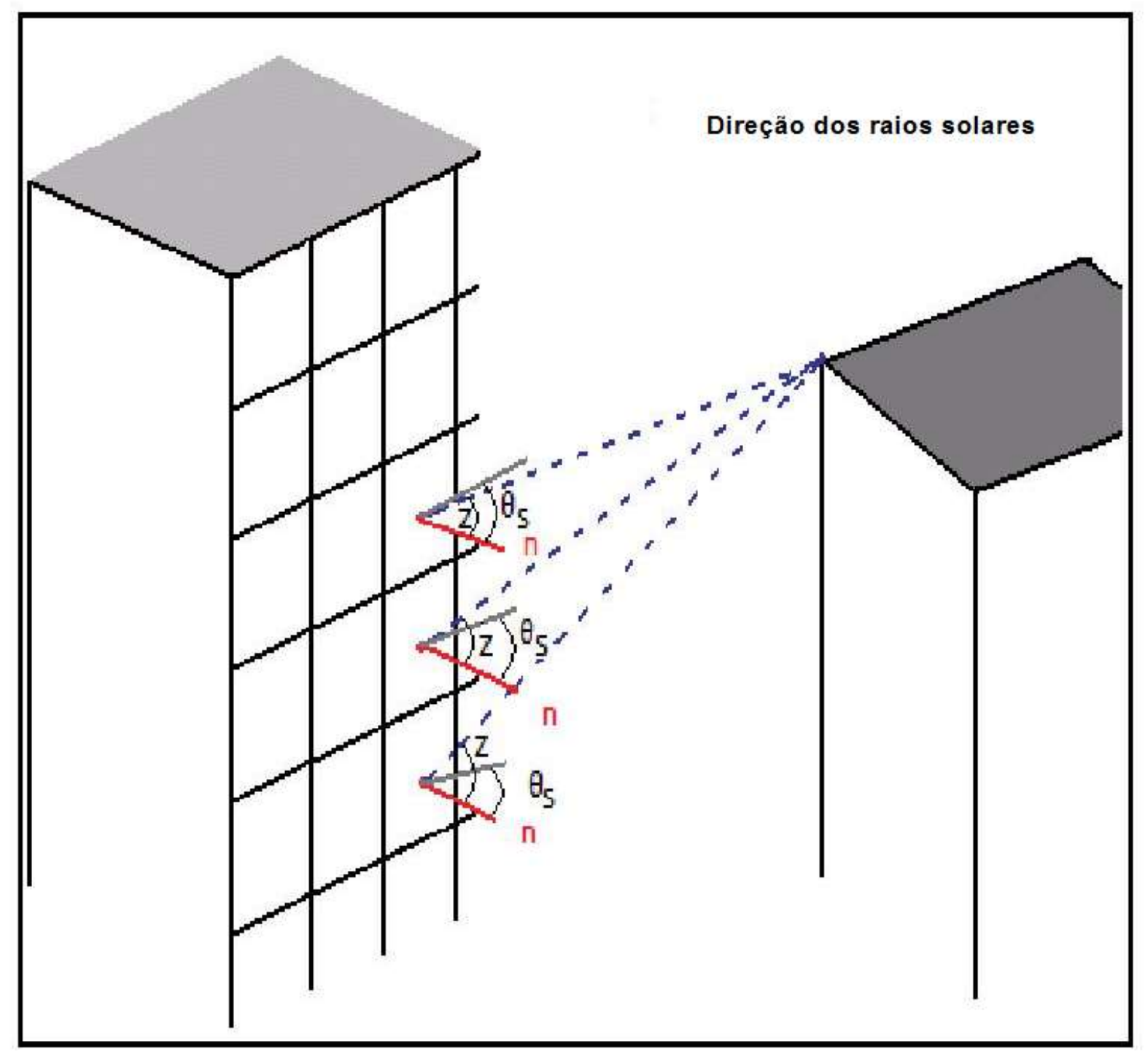

Figura 19 - Análise do fenômeno projeção de sombra (cast shade).

Nas situações de sombreamento e projeção de sombra, de forma a otimizar o processo, uma vez determinada uma célula pertencente a um edifício, onde se 
verifique que esta está na sombra, todas as células na vertical abaixo dessa estão invisíveis (Figura 20).

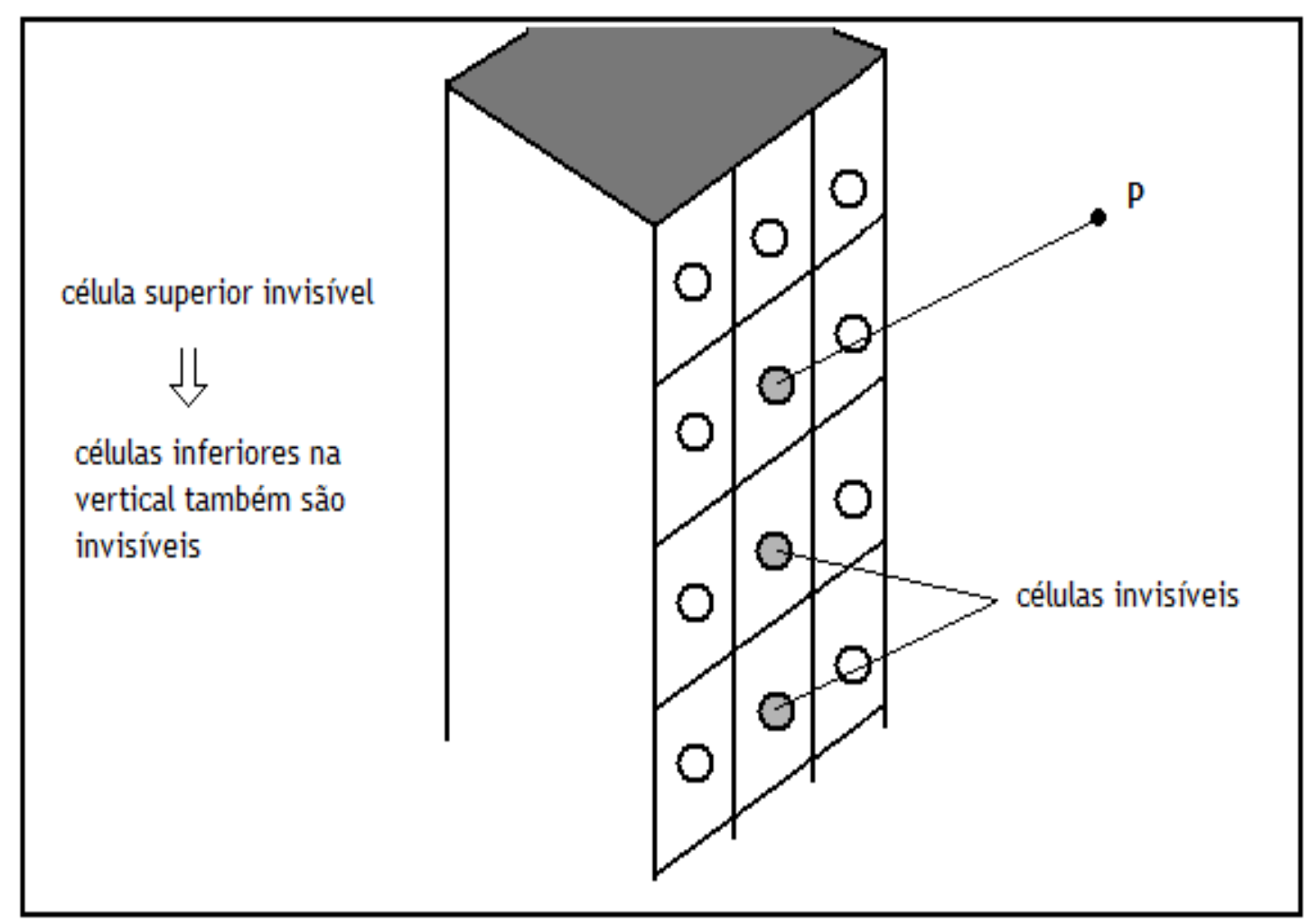

Figura 20 - Representação em um edifício da visibilidade entre células.

Outra análise pode ser feita de forma a otimizar o processo de análise de sombreamento. Tome-se o ponto $\mathrm{P}$ como a posição do Sol numa determinada altura do ano. Em determinadas posições pode-se logo determinar se um lado do edifício é ou não totalmente visível, tendo em conta os ângulos associados ao ponto $\mathrm{P}$ e os ângulos de cada um dos lados do edifício, ou seja, a sua orientação (ângulos de azimute $\alpha$ ) (Figura 21). 


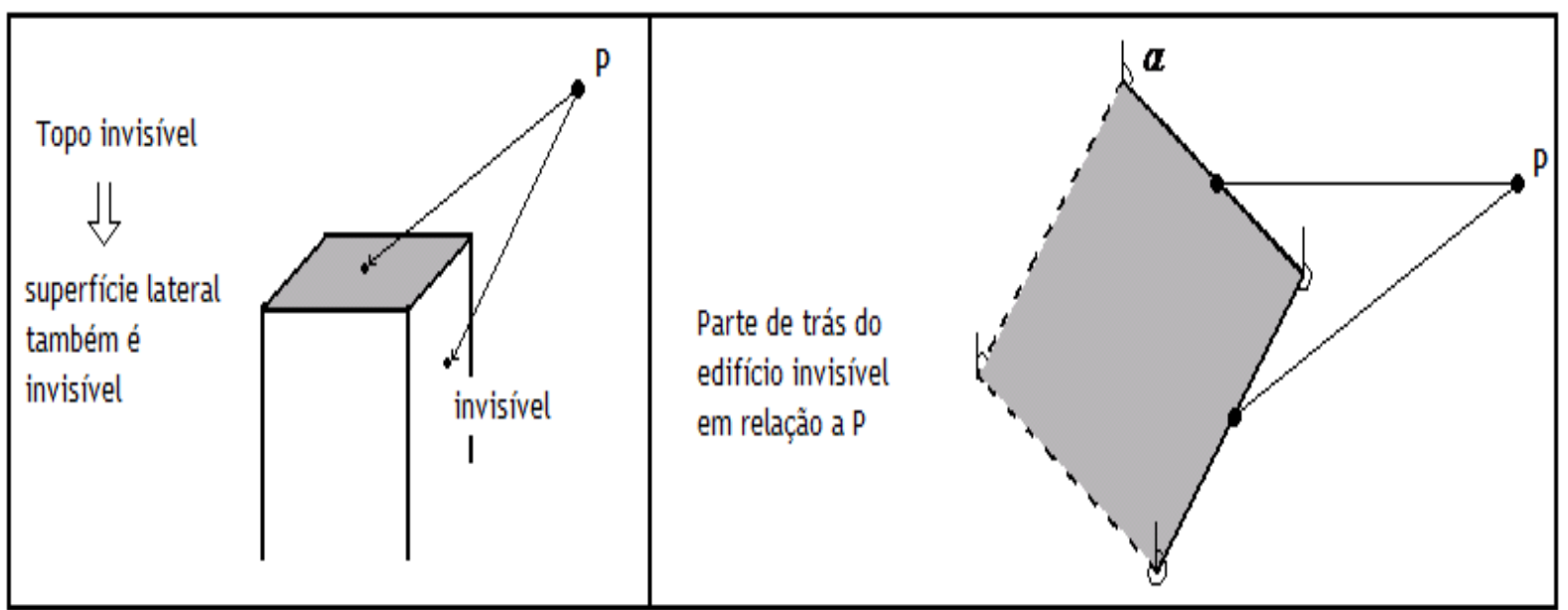

Figura 21 - Determinação das superfícies visíveis num edifício.

Então para cada célula da representação 3D é calculado o ângulo de incidência entre a fonte de luz, neste caso o sol, e a normal a superfície da célula. Esse ângulo de incidência é dado pela equação (3.8). Uma vez que cada célula possui a informação relativa à sua inclinação e orientação ( $\beta$ e $\alpha$, respectivamente) as outras variáveis apenas dependem do dia de simulação é da latitude da zona geográfica em estudo.

\subsubsection{Estimativa de radiação total}

Após a manipulação das camadas (layers), anteriormente descrita, para melhorar o tratamento de dados correspondente ao SIG a analisar, procede-se o cálculo da radiação solar, de forma a poder obter um melhor conhecimento do potencial fotovoltaico na região pretendida. Para tal, define-se um intervalo de tempo onde será efetuado esse cálculo. O mais natural é a análise horária, pois a trajetória do Sol ao longo do dia ira influenciar a radiação incidente sobre uma superfície, sobretudo quando se trata de uma zona urbana. Assim sendo, recorre-se a modelos de estimativa horária, a partir dos valores médios diários. Para uma melhor compreensão da metodologia sugerida, os pontos que se seguem pretendem resumir os passos necessários para obter uma estimativa da radiação solar num ambiente urbano: 
- Calcular, para cada dia, os ângulos de nascer e pôr do sol, determinados pela equação (3.7), uma vez que estes apenas dependem da latitude do local e do dia de simulação;

- Calcular a irradiação extraterrestre diária no plano horizontal, através da equação (3.6);

- Calcular o índice de atenuação, $\mathrm{K}_{\mathrm{T}}$, utilizando a equação (3.9);

- Determinar a irradiação diária difusa pela equação (3.10);

- Calcular a relação entre a radiação direta numa superfície, inclinada e orientada, é a radiação incidente numa superfície na horizontal, através da equação:

$$
\mathrm{R}_{\mathrm{b}}=\cos \theta_{\mathrm{s}} / \cos \theta_{\mathrm{z}}
$$

- Calcular os valores horários das componentes da radiação para o plano da superfície, através das seguintes equações:

$$
\begin{aligned}
& h_{b}=\left(h-h_{d}\right) \cdot h_{b} \\
& h_{d}=h_{d}[(1+\cos \beta) / 2] \\
& h_{\rho}=h[(1-\cos \beta) / 2]
\end{aligned}
$$

- Após a determinação das componentes da radiação solar, no plano da superfície e necessário fazer uma análise de sombreamentos, tendo em conta os aspectos referidos no item 3.5.1.2. Para tal, é necessário ter em conta a posição do Sol, facilmente definida no espaço pelas equações (3.3) e (3.5).

E realiza então uma análise de sombra de uma colina (hill shade) e projeção de sombras (cast shade);

- Caso a superfície analisada esteja sujeita a sombreamento, a componente horária da radiação direta é nula, e por último calcula-se a radiação horária total incidente sobre a superfície, através da equação (3.18). 
De forma a obter uma estimativa anual da radiação total, este processo é realizado repetidamente ao longo dos dias, ou seja, integrando a radiação total ao longo do dia e posteriormente ao longo do ano. Este tipo de metodologia é bastante útil, pois permite estimar e avaliar o potencial de produção de sistemas BIPV em ambiente urbano, com base na radiação total obtida em cada superfície de cada edifício. A integração diária neste tipo de modelos é fundamental, pois assim permite identificar pontos de sombreamentos que ocorrem durante o dia. 


\section{APLICAÇÃO DA METODOLOGIA}

\subsection{ESTUDO DE CASO}

Este estudo de caso tem por objetivo avaliar o impacto da instalação de células fotovoltaicas de filme fino, na forma de módulos, integrada ao envelope de um prédio para geração de energia elétrica, reduzindo assim parte da energia demandada, num edifício típico comercial.

\subsubsection{Característica do prédio comercial do estudo}

O prédio estudado consiste em um edifício comercial de 13 pavimentos, de 18 metros de largura frontal por 27 metros de profundidade e 41 metros de altura dos pavimentos, denominado de "The Classic Tower", localizado na Rua Dr. Neto de Araújo, 320, Vila Mariana, São Paulo, SP.

O posicionamento do prédio em relação ao norte foi obtida a partir do aplicativo Google Earth [46], (Figura 22). Latitude de $23^{\circ} 35^{\prime}$ sul, longitude de $46^{\circ} 37^{\prime}$ oeste, altitude de $821 \mathrm{~m}$. As fachadas disponíveis foram medidas e confrontadas com a planta do projeto arquitetônico da edificação, anexo 1. Importante ressaltar que para efeito de área disponível nas fachadas não foi considerado os dutos para ar condicionado, indicados na Figura 25. 


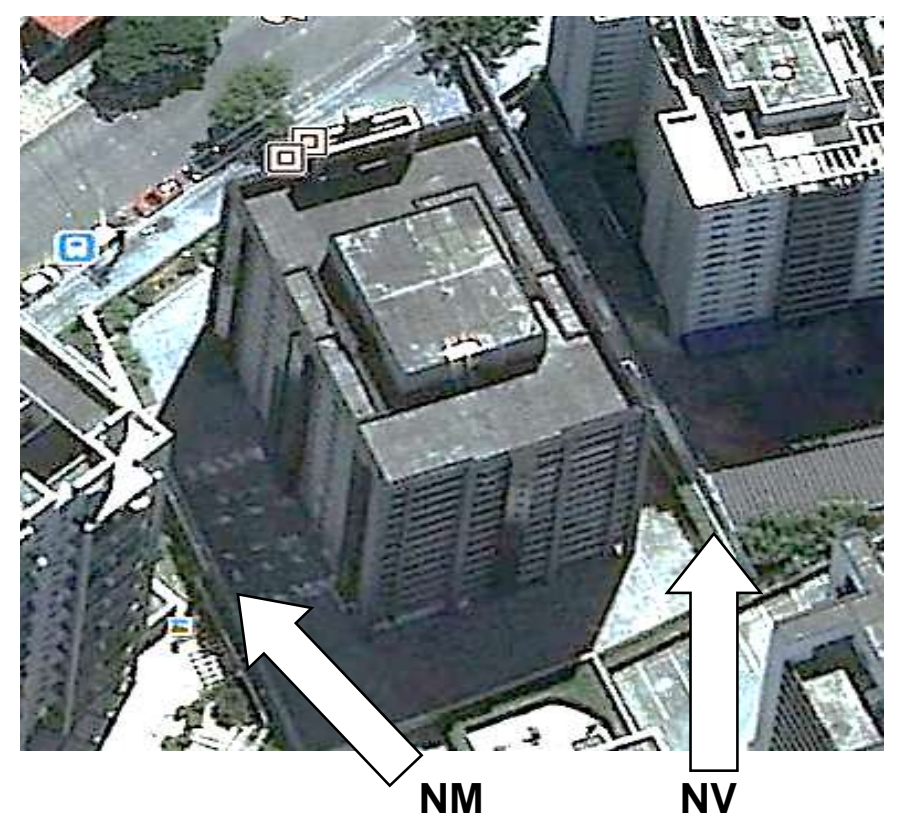

Figura 22 - Orientação geográfica.

O consumo mensal de energia elétrica foi obtido a partir das faturas de fornecimento de energia elétrica pela concessionária AES Eletropaulo, ano de 2011, medidor $\mathrm{N}^{0} 8429826$, fator multiplicador 40 , classe comercial, faturamento trifásico e tensão nominal 127/220 V(BT), Tabela 4.

As cargas de energia elétrica são de bombas de água, elevadores, vigilância eletrônica e iluminação. A iluminação artificial é utilizada durante o dia e a noite utilizada-se iluminação externa e de segurança.

O horário de funcionamento comercial do edifício está compreendido entre $8 \mathrm{~h} 00$ e $18 \mathrm{~h} 00$ horas, de segunda a sexta feira, sábados entre $8 \mathrm{~h} 00$ às $12 \mathrm{~h} 00$ horas, exceto feriados.

A simulação do potencial de geração fotovoltaica foi feita a partir de análise da irradiação mensal e anual. Lembrando que os dados de geração e consumo são referentes ao ano de 2011. O consumo médio mensal para o ano considerado foi de 7,24 MWh/mês. 
Tabela 4 - Consumo mensal do ano 2011.

\begin{tabular}{|cc|}
\hline Mês/2011 & $\begin{array}{c}\text { Consumo } \\
(\mathrm{kWh})\end{array}$ \\
\hline 01 & 6320 \\
02 & 6160 \\
03 & 6600 \\
04 & 6960 \\
05 & 7120 \\
06 & 7680 \\
07 & 7680 \\
08 & 7920 \\
09 & 7800 \\
10 & 8040 \\
11 & 7360 \\
12 & 7240 \\
\hline
\end{tabular}

\subsubsection{Sombreamento nas fachadas}

O prédio em estudo possui sombreamentos, conforme tratado no item 3.5.1.2, provocado pelas construções vizinhas e que pode ser identificado na Figura 22. Para calcular o sombreamento médio anual no prédio, foi utilizado o programa sunerarthools [50]. A partir das imagens com a trajetória percorrida pelo sol, foram verificadas as projeções de sombra nas quatro fachadas, nordeste, sudeste,sudoeste e noroeste do prédio. Assim, foi verificada a projeção das sombras nas datas correspondentes aos quatro períodos marcados pela declinação solar durante $\mathrm{o}$ ano, que são os solstícios e os equinócios, meses de março, junho, setembro e dezembro.

Uma vez simuladas as projeções através do programa, fotos das fachadas e observações diárias durante o ano para cada período, foi estimada uma média anual 
de menos $30 \%$ de sombra para cada fachada. Este valor foi multiplicado pela área real de cada orientação. Exemplo: Área Envidraçada (N.O.) $\left(347,143\right.$ x 0,7=243 $\left.\mathrm{m}^{2}\right)$

Com base nestes valores, foram obtidas as áreas úteis reais para a instalação do sistema FV, ou seja, as áreas correspondentes a cada orientação, subtraídas da área de sombreamento correspondente, tabela 5.

Tabela 5 - Área disponível para instalação de células - módulos FV.

\begin{tabular}{|c|c|}
\hline $\begin{array}{c}\text { Área disponível } \\
(\text { Sem sombras }-30 \%)\end{array}$ & $\begin{array}{c}\text { Área útil }\left(\mathbf{m}^{\mathbf{2}}\right) \\
\text { (Com sombras) }\end{array}$ \\
\hline $\mathrm{AE}($ N.O.) $(347,1430 \times 0,7)$ & 243 \\
\hline $\mathrm{AE}($ S.E. $)(192,8570 \times 0,7)$ & 135 \\
\hline $\mathrm{AE}($ S.O. $)(77,1429 \times 0,7)$ & 54 \\
\hline $\mathrm{AE}($ N.E. $)(137,1430 \times 0,7)$ & 96 \\
\hline Subtotal de AE & 528 \\
\hline ADSV( N.O.) $(527,1430 \times 0,7)$ & 369 \\
\hline ADSV( S.E.) $(292,8670 \times 0,7)$ & 205 \\
\hline ADSV( S.O.) $(188,5710 \times 0,7)$ & 132 \\
\hline ADSV( N.E.) $(338,5710 \times 0,7)$ & 237 \\
\hline Subtotal de ADSV & 943 \\
\hline Total de AE + ADSV & 1471 \\
\hline
\end{tabular}

Os locais disponíveis para simulação do potencial de geração FV foram calculados para as áreas externas envidraçadas $(A E)$, para as áreas disponíveis sem vidros $(A D S V)$ e para a área total $(A T)=(A E+A D S V)$ com possibilidade de aproveitamento para instalação de módulos FV, conforme a divisão, apresentadas na Tabela 5 e Figuras 23 a 27. 


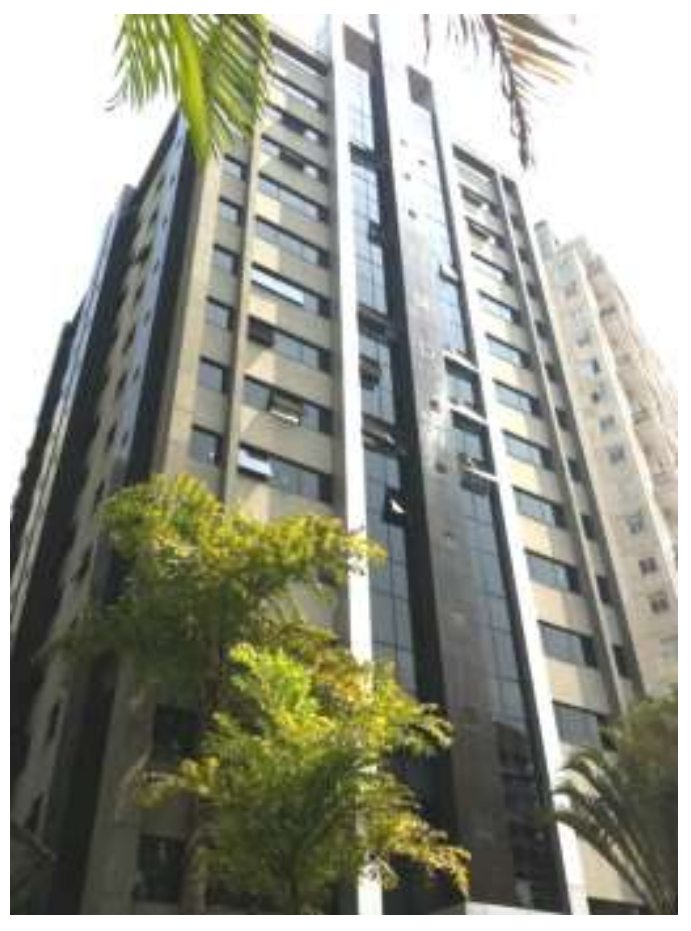

Figura 23 - Fachada N.E.

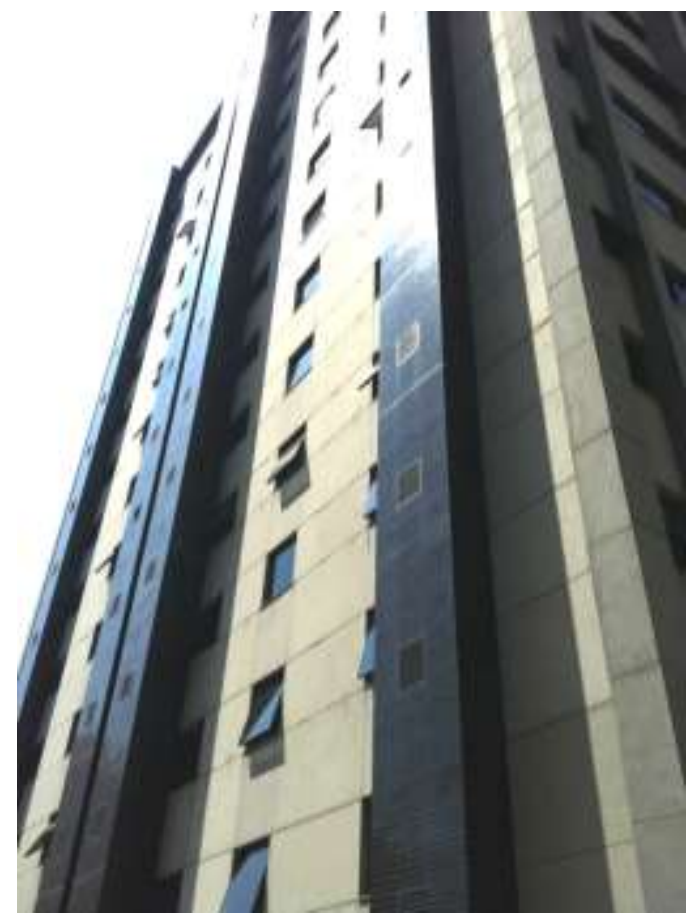

Figura 24 - Fachada N.O

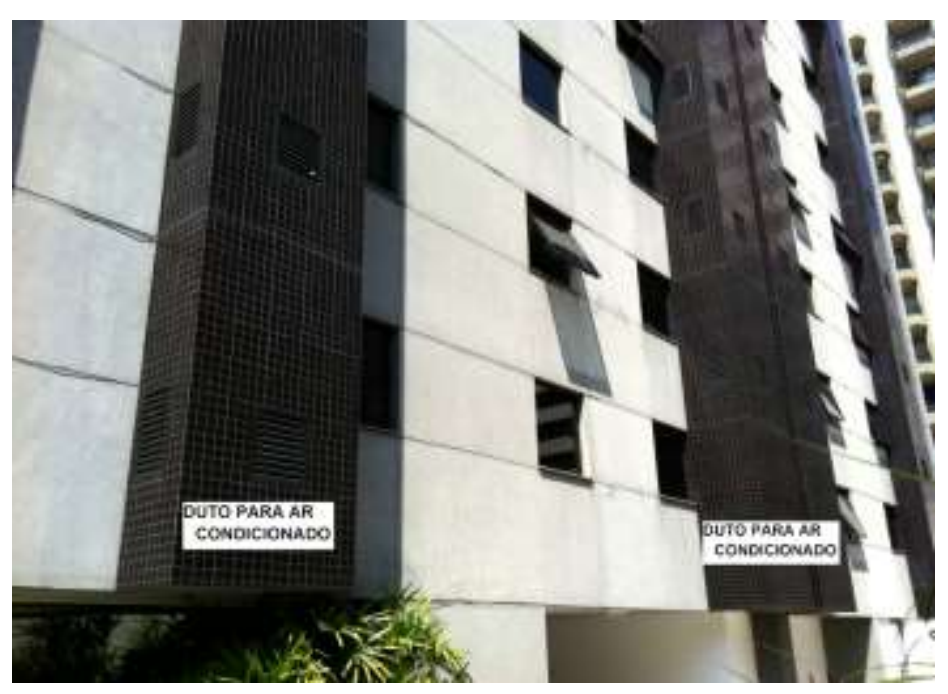

Figura 25 - Fachada N.O - Detalhes 


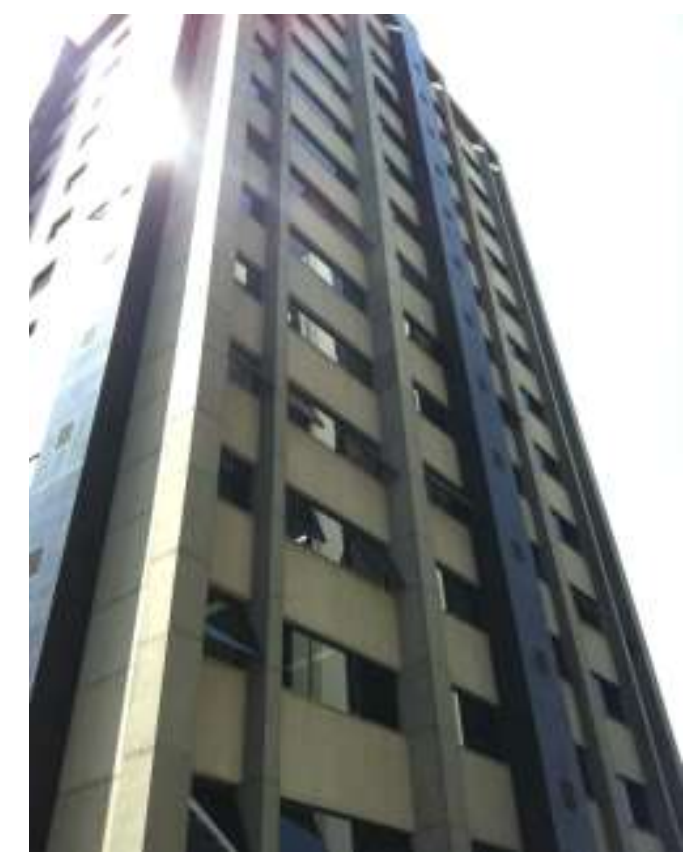

Figura 26 - Fachada S.O.

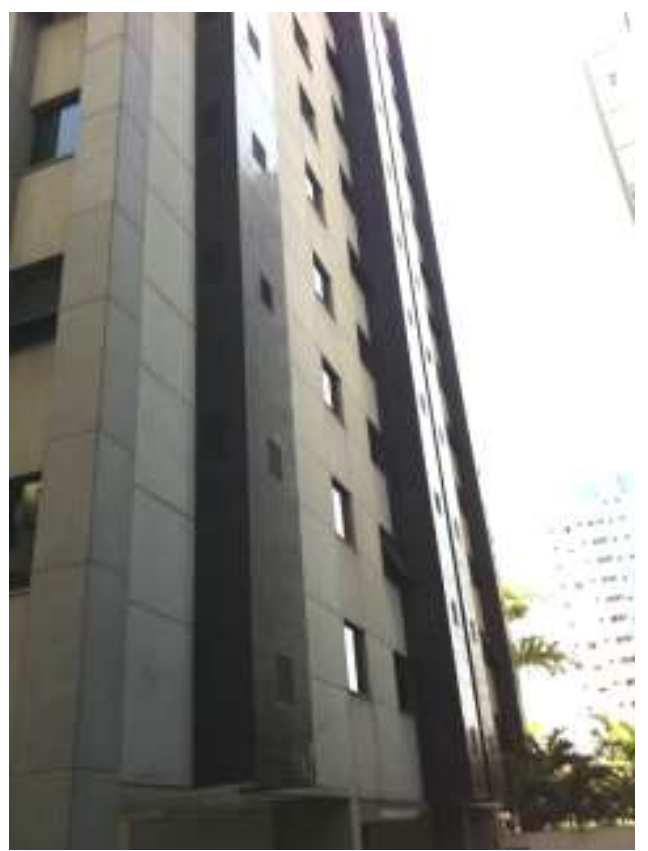

Figura 27 - Fachada S.E.

Nas Figuras 28 a 35 foram identificadas as áreas sombreadas pelas edificações vizinhas, para os períodos de solstício e equinócio.

Como o valor de área sombreada foi obtido de forma total anual, foi necessário que se identificasse a quantidade de área sombreada para cada orientação, uma vez que estas recebem quantidades de radiação solar diferente e estas quantidades estão relacionadas com a área.

Para obter a média anual de área sombreada (real ou estimada) para cada orientação, foi verificada uma relação entre área total de sombra (real ou estimada) e área do prédio estudada. 


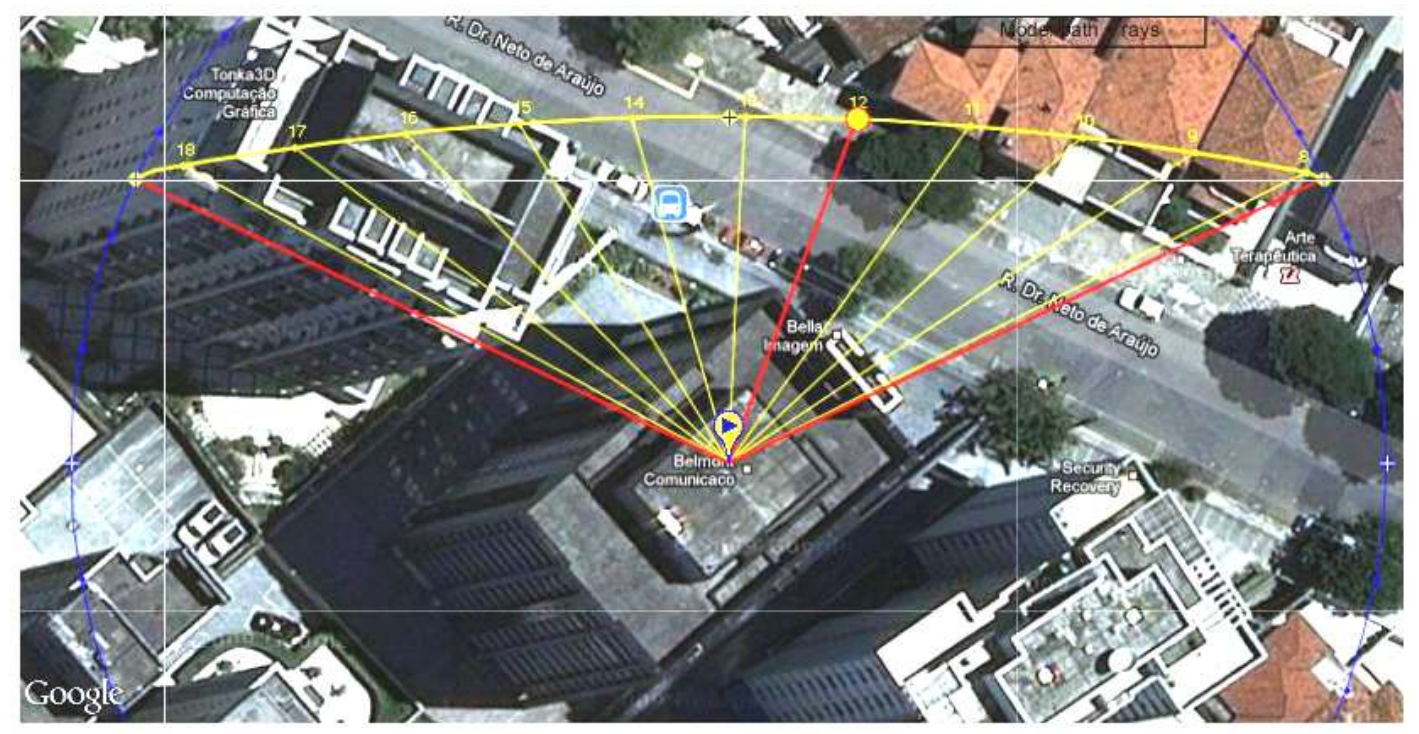

Figura 28 - 22/06/2011 Incidência dos raios de sol

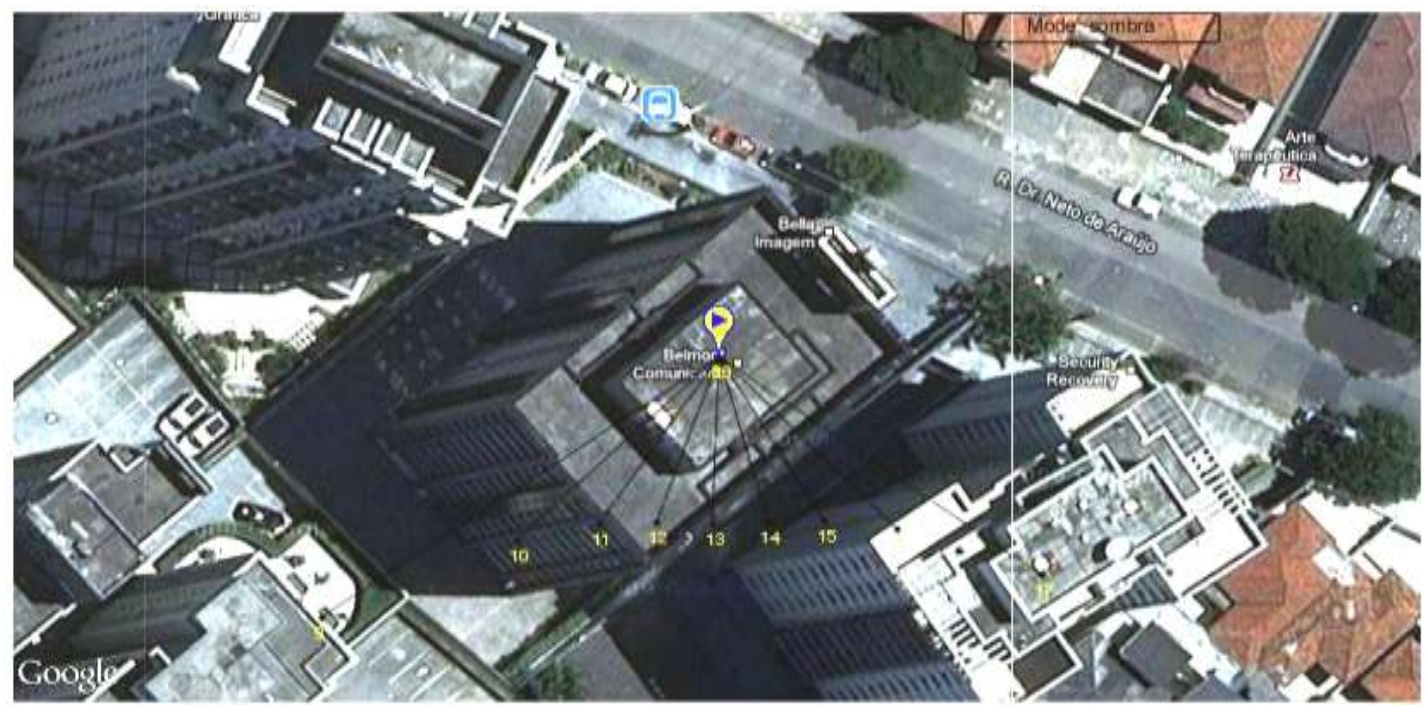

Figura 29 - 22/06/2011 Projeção das sombras 


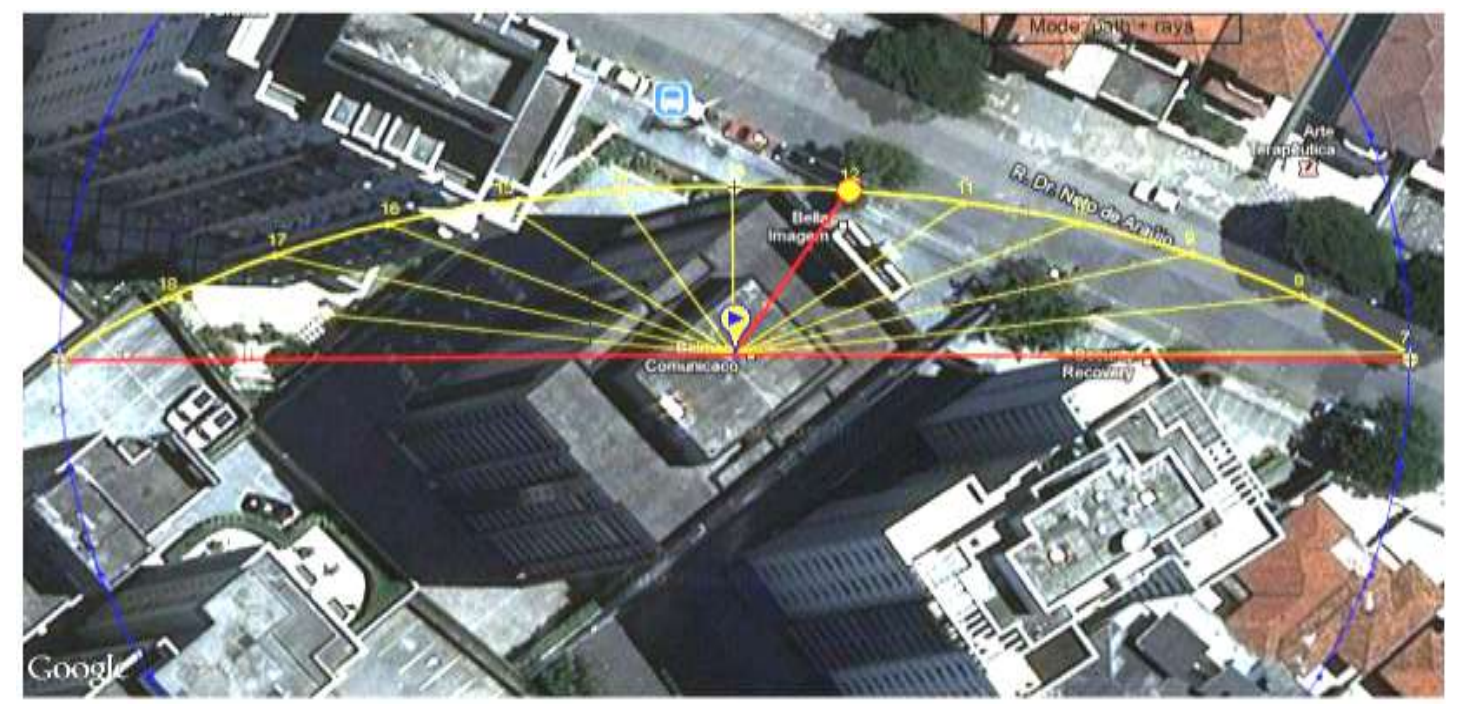

Figura 30 - 23/09/2011 Incidência dos raios de sol

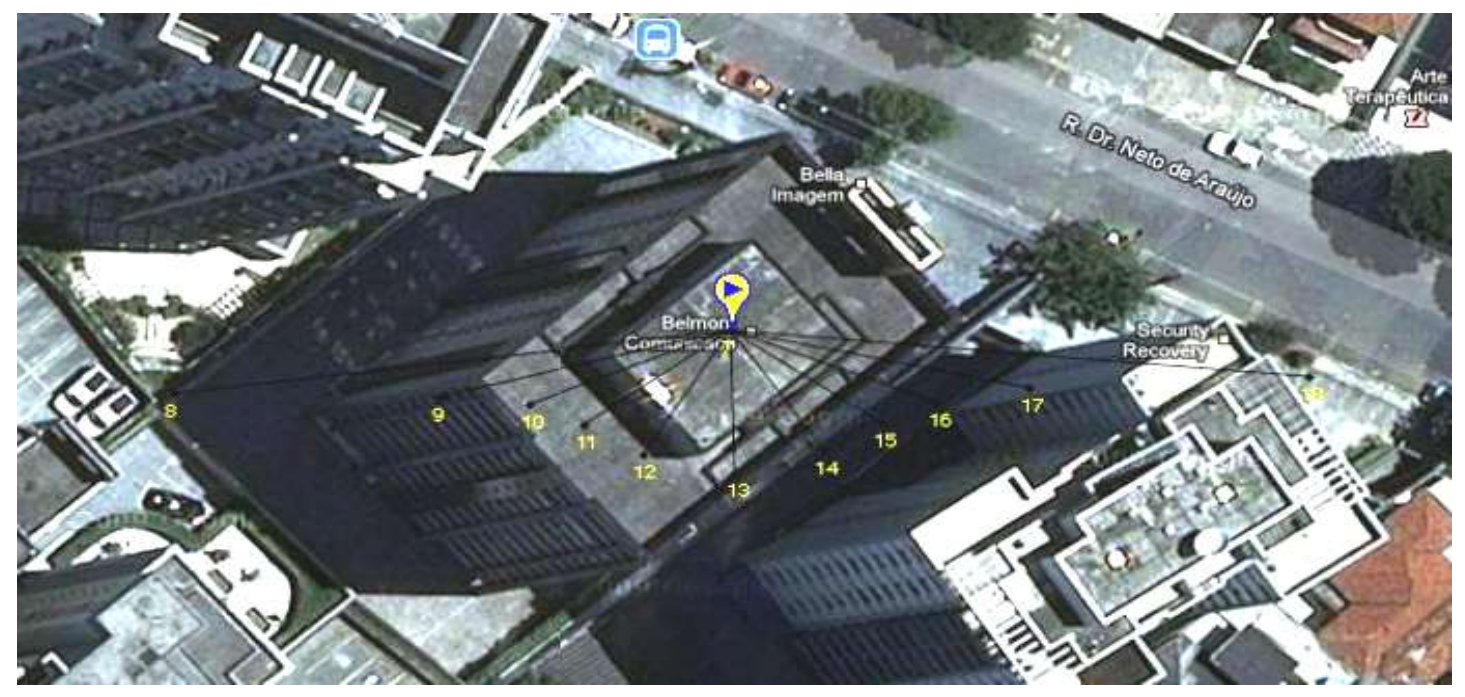

Figura 31 - 23/09/2011 Projeção das sombras 


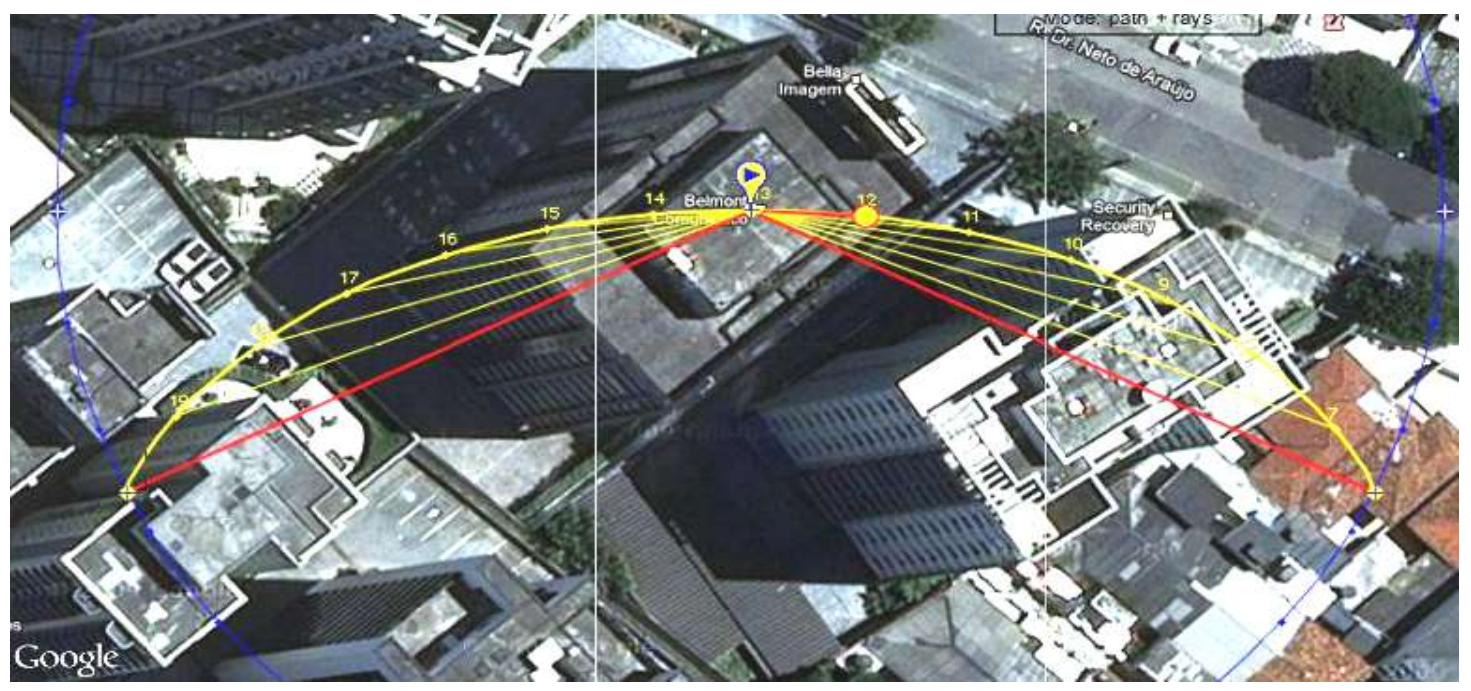

Figura 32 - 21/12/2011 Incidência dos raios de sol

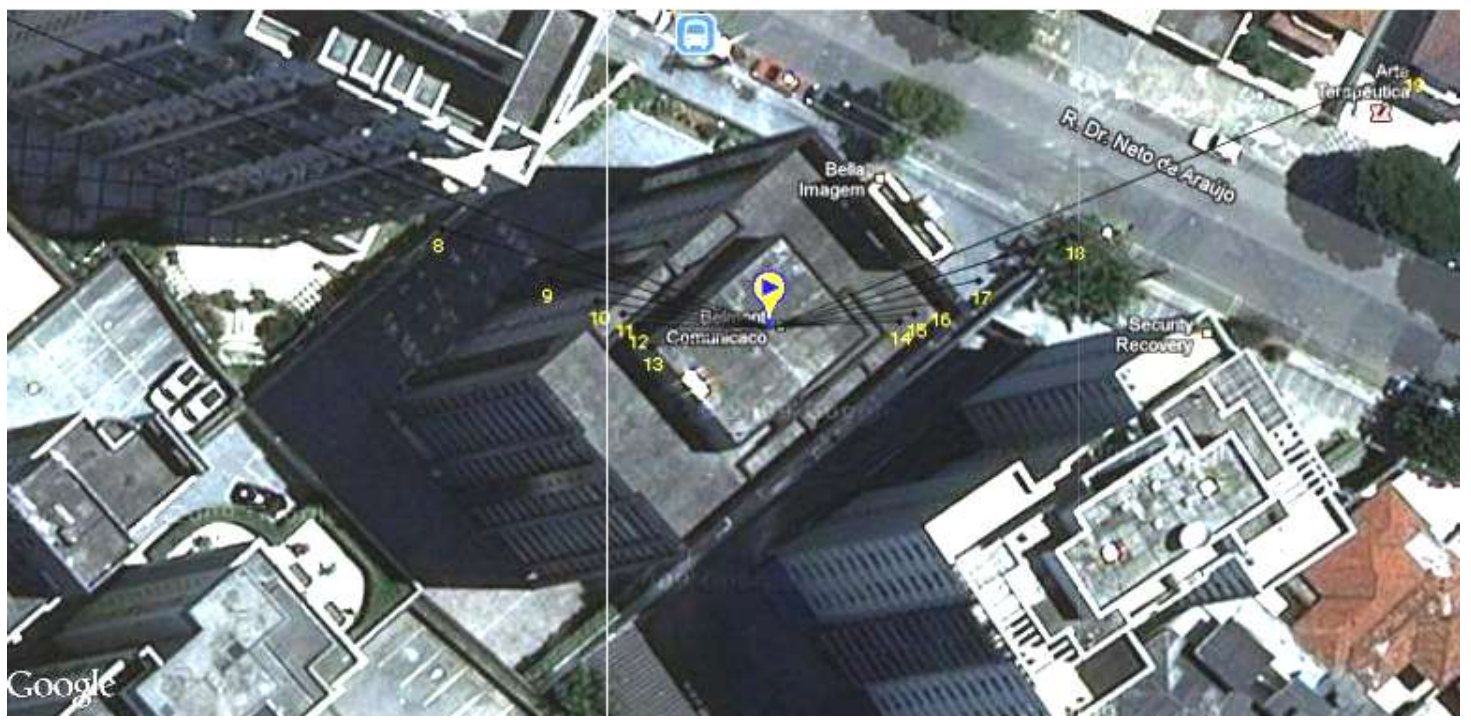

Figura 33 - 21/12/2011 Projeção das sombras 


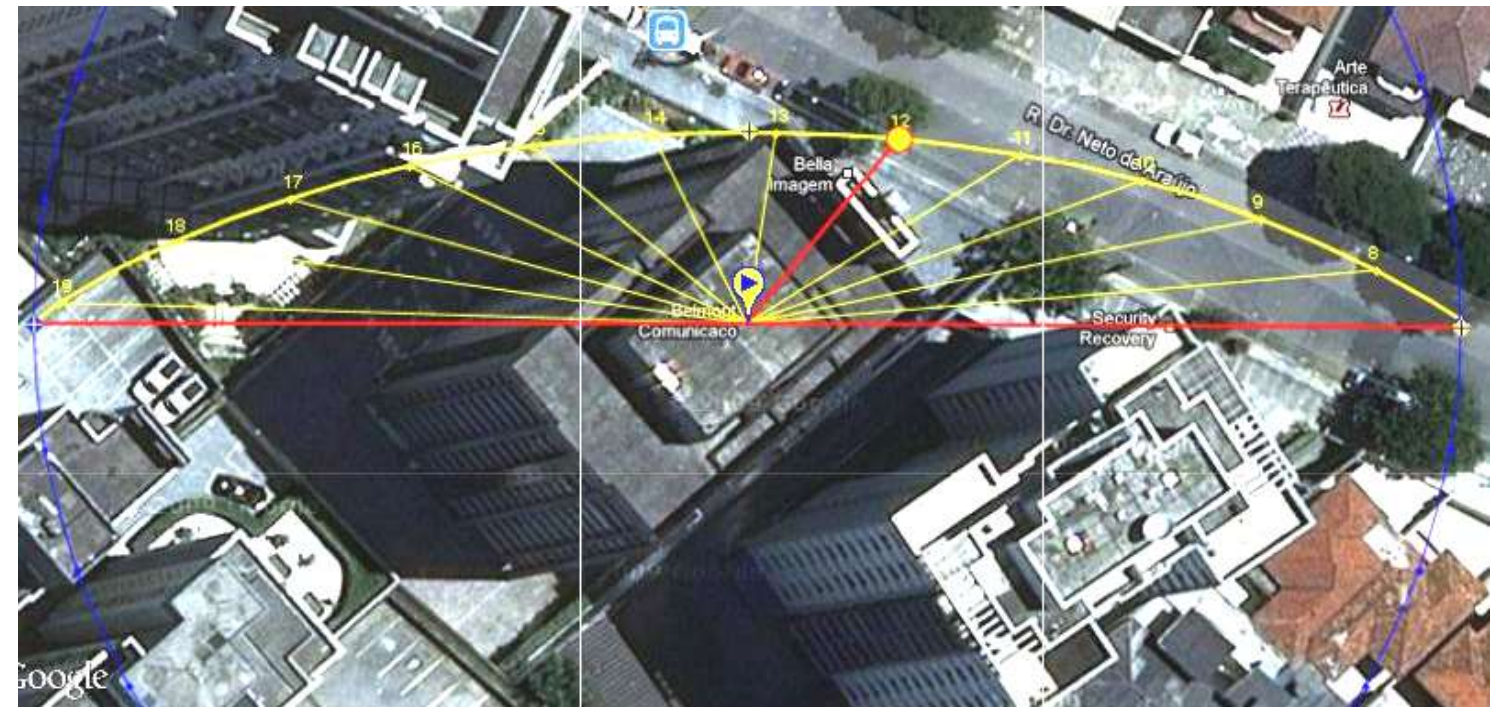

Figura $34-21 / 03 / 2011$ Incidência dos raios de sol

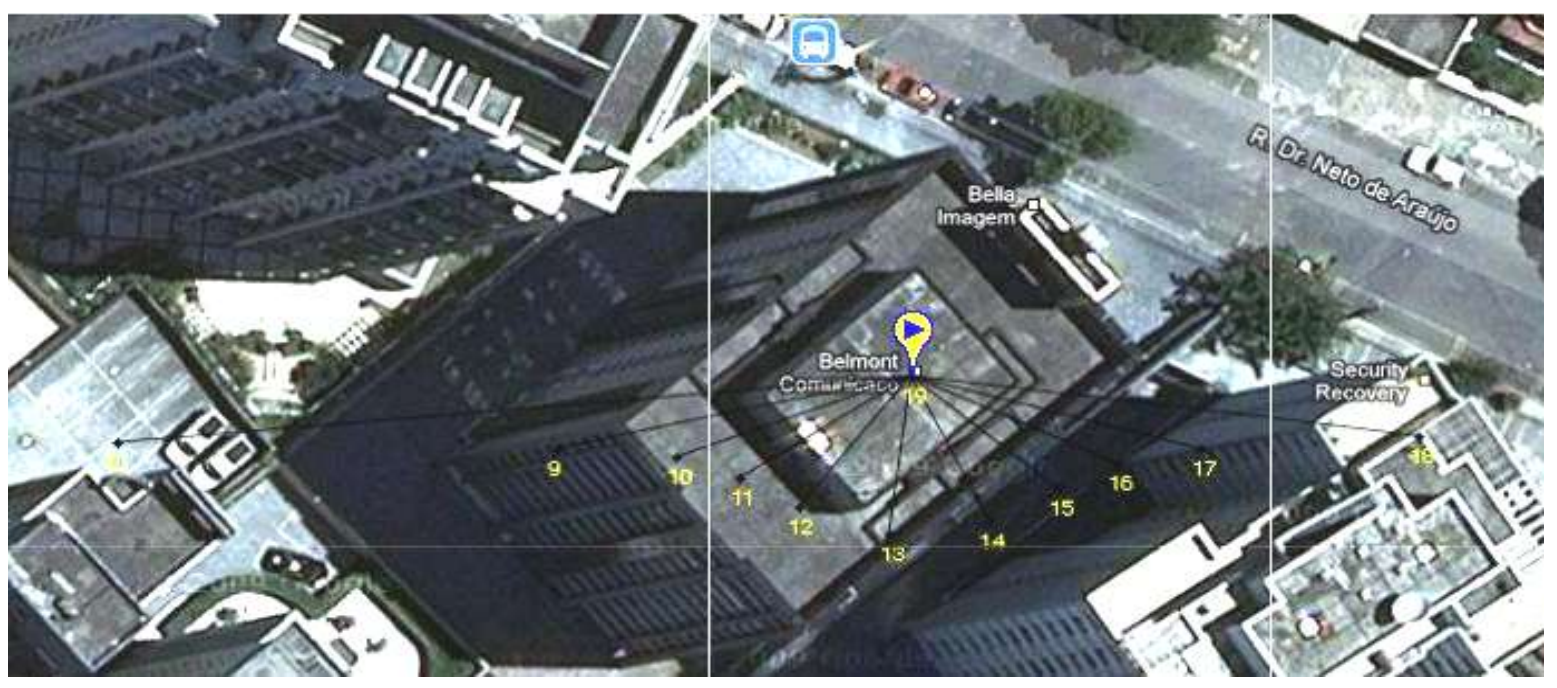

Figura 35 - 21/03/2011 Projeção das sombras 


\subsection{DADOS DE IRRADIAÇÃO SOLAR PARA O LOCAL DE ESTUDO}

A radiação incidente numa superfície, tal como já mencionado, depende da latitude do local, do dia do ano, da sua própria inclinação e orientação. O local escolhido para testar o modelo foi à cidade de São Paulo, no ano de 2011. A declinação esta relacionada com o dia do ano e por isso é uma das variáveis que influencia a radiação incidente. A (tabela 6) permite observar a variação da declinação ao longo do ano 2011.

Tabela 6 - Variação da declinação magnética [42].

\begin{tabular}{|c|c|c|c|}
\hline Dia & Mês & Ano & Graus: Minutos \\
\hline 1 ao 31 & 01 & 2011 & -20.50 à -20.51 \\
\hline 1 ao 28 & 02 & 2011 & -20.51 à -20.52 \\
\hline 1 ao 31 & 03 & 2011 & -20.52 à -20.53 \\
\hline 1 ao 30 & 04 & 2011 & -20.53 à -20.54 \\
\hline 1 ao 31 & 05 & 2011 & -20.54 à -20.55 \\
\hline 1 ao 30 & 06 & 2011 & -20.55 à -20.56 \\
\hline 1 ao 31 & 07 & 2011 & -20.56 à -20.57 \\
\hline 1 ao 31 & 08 & 2011 & -20.57 à -20.58 \\
\hline 1 ao 30 & 09 & 2011 & -20.58 à -20.59 \\
\hline 1 ao 31 & 10 & 2011 & -20.59 à -20.60 \\
\hline 1 ao 30 & 11 & 2011 & -20.60 à -20.61 \\
\hline 1 ao 31 & 12 & 2011 & -20.61 à -20.62 \\
\hline
\end{tabular}

Outra variável que também influencia a radiação incidente é a radiação global no local, calculada pela equação (3.6). Na tabela a seguir estão disponíveis os dados relativos à radiação média para o local em estudo, no plano horizontal, tabela 7. Adicionalmente, são mostrados o valor da menor diária média mensal (Mínimo), da maior diária média mensal (Máximo), da diária média anual (Média). 
Tabela 7 - Radiação média no plano horizontal $\left[\mathrm{kWh} / \mathrm{m}^{2}\right.$. dia]

\begin{tabular}{|c|c|}
\hline Mês/2011 & $\begin{array}{c}\text { Radiação } \\
\left(\mathrm{kWh} / \mathrm{m}^{2} \text {.dia }\right)\end{array}$ \\
\hline 01 & 4,5000 \\
\hline 02 & 5,0000 \\
\hline 03 & 4,0600 \\
\hline 04 & 3,1600 \\
\hline 05 & 3,1900 \\
\hline 06 & 2,9400 \\
\hline 07 & 3,2200 \\
\hline 08 & 3,7200 \\
\hline 09 & 3,7500 \\
\hline 10 & 4,0300 \\
\hline 11 & 5,0000 \\
\hline 12 & 4,5300 \\
\hline $\begin{array}{c}\text { Média anual } \\
2011\end{array}$ & 3,9600 \\
\hline
\end{tabular}




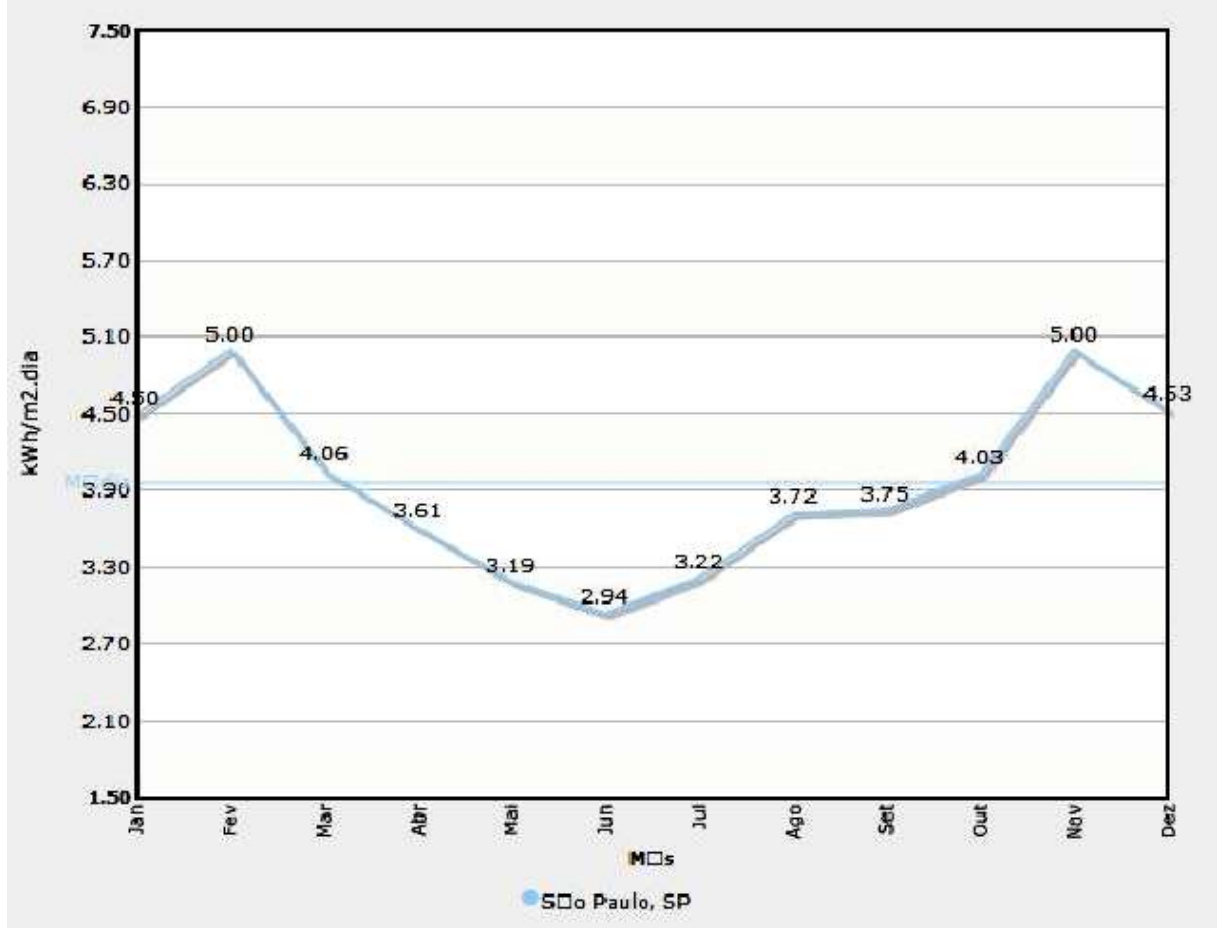

Gráfico 1 - Radiação Solar no Plano Horizontal, 2011. [43]

Os valores apresentados mostram as radiações médias, com as seguintes observações:

- o ângulo de inclinação é arredondado para valores inteiros de graus, em função da precisão dos instrumentos de medição da inclinação usada para instalação de sistemas fotovoltaicos em campo, chamados de goniômetro, que costumam apresentar erros da ordem de alguns graus;

- o valor mínimo de inclinação admitido é de $10^{\circ}$, pois o CEPEL (Centro de Pesquisas de Energia Elétrica) não recomenda a instalação de painéis fotovoltaicos com inclinação inferior a esta para evitar o acúmulo de água e sujeira;

- as orientações dos módulos fotovoltaicos são também dadas, sendo admitidas somente orientação na direção Norte (indicado por N). 
A conversão dos valores de irradiação no plano horizontal para os planos inclinados é calculada segundo o método de Liu \& Jordan (1962) [44] isotrópico estendido por Klein (1977) [45].

\subsubsection{Radiação solar incidente no local da aplicação}

Neste item da aplicação prática busca-se quantificar a radiação solar global incidente sobre o painel fotovoltaico, instalados nas diferentes áreas das fachadas de forma a podermos calcular a energia gerada.

Os dados de radiação solar podem estar especificados em termos de fluxo de potência (valores instantâneos) ou energia (com diversos períodos de integração) por unidade de área. A forma mais comum de apresentação dos dados de radiação é através de valores médios mensais para a energia acumulada ao longo de um dia.

Uma forma bastante conveniente de se expressar o valor acumulado de energia solar ao longo de um dia é através do número de horas de Sol Pleno. Esta grandeza reflete o número de horas em que a radiação solar deve permanecer constante e igual a $1 \mathrm{~kW} / \mathrm{m}^{2}\left(1000 \mathrm{~W} / \mathrm{m}^{2}\right)$ de forma que a energia resultante seja equivalente à energia acumulada para o dia e local da aplicação. A seguir vamos aplicar os passos necessários para obter uma estimativa da radiação solar num ambiente urbano:

- valores estudados de irradiação total diária com base nas equações (3.6), (3.7), (3.9), (3.10), (3.12) e (3.21), irradiação extraterrestre $\left(\mathbf{H}_{0}\right)$, ângulos de nascer, $\omega_{\mathrm{s}}$ e pôr $\omega_{\mathrm{s}}$, do sol, índice de atenuação, $\left(\mathbf{K}_{\mathbf{T}}\right)$, irradiação direta $\left(\mathbf{H}_{\mathbf{b}}\right)$, irradiação difusa, $\left(\mathbf{H}_{\mathbf{d}}\right)$, irradiação total $\left(\mathrm{H}_{\mathrm{t}}\right)$ relação $\left(\mathbf{R}_{\mathbf{b}}\right)$, para três cidades brasileiras, São Paulo, Salvador e Porto Alegre.

- para validar estes valores, foram comparados com o programa SunData [43], apontados nas tabelas 8 a 13 ; 
Tabela 8 - São Paulo, módulos instalados na horizontal.

\begin{tabular}{|c|c|c|c|c|c|c|c|}
\hline & \multirow{3}{*}{$\begin{array}{c}H_{t} \\
\left(k W h / m^{2}\right)\end{array}$} & \multirow{3}{*}{$\mathbf{R}_{\mathrm{b}}$} & \multirow{3}{*}{$\begin{array}{c}\mathbf{H}_{\mathrm{t}} \\
\text { Sundata }\end{array}$} & \multirow{3}{*}{$\begin{array}{l}\mathbf{H}_{\mathbf{t}}(\%) \\
\text { Planilha/ } \\
\text { Sundata }\end{array}$} & \multirow{3}{*}{ H } & \multirow[b]{2}{*}{$\alpha$} & \multirow[b]{2}{*}{$\omega$} \\
\hline & & & & & & & \\
\hline & & & & & & $\alpha\left[^{\circ}\right]$ & $\boldsymbol{\omega}\left[{ }^{\circ}\right]$ \\
\hline & & & & & & & $\begin{array}{l}12: 28 \\
\end{array}$ \\
\hline \multirow[t]{2}{*}{$21 /$ mar } & 4,0535 & 0,8316 & 4,0600 & $-0,1580$ & 4,0600 & $-20,8800$ & 7,0000 \\
\hline & & & & & & & $12: 28$ \\
\hline \multirow[t]{2}{*}{ 22/jun } & 2,9319 & 0,7186 & 2,9400 & $-0,2700$ & 2,9400 & $-20,9300$ & 7,0000 \\
\hline & & & & & & & $12: 28$ \\
\hline \multirow[t]{2}{*}{$23 /$ set } & 3,7441 & 0,8338 & 3,7500 & $-0,1580$ & 3,7500 & $-20,9800$ & 7,0000 \\
\hline & & & & & & & $13: 36$ \\
\hline 21/dez & 4,5257 & 0,8972 & 4,5300 & $-0,0009$ & 4,5300 & $-21,0300$ & 24,0000 \\
\hline
\end{tabular}

$\beta=$ inclinação dos módulos a $10^{\circ}$

$\rho=$ refletividade de $100 \%$

Tabela 9 - São Paulo, módulos instalados a 24ํㅜ, igual à latitude.

\begin{tabular}{|c|c|c|c|c|c|c|c|}
\hline & \multirow{3}{*}{$\begin{array}{c}\mathrm{H}_{\mathrm{t}} \\
\left(\mathrm{kWh} / \mathrm{m}^{2}\right)\end{array}$} & \multirow{3}{*}{$\begin{array}{c}\mathbf{R}_{\mathrm{b}} \\
(3.21)\end{array}$} & \multirow{3}{*}{$\begin{array}{c}H_{t} \\
\text { Sundata }\end{array}$} & \multirow{3}{*}{$\begin{array}{l}\mathbf{H}_{\mathbf{t}}(\%) \\
\text { Planilha/ } \\
\text { Sundata }\end{array}$} & \multirow{3}{*}{ H } & \multirow{2}{*}{\multicolumn{2}{|c|}{$\omega$}} \\
\hline & & & & & & & \\
\hline & & & & & & $\alpha\left[^{\circ}\right]$ & $\omega\left[^{\circ}\right]$ \\
\hline & & & & & & & $12: 28$ \\
\hline \multirow[t]{2}{*}{ 21/mar } & 4,1381 & 0,6706 & 4,1500 & $-0,2800$ & 4,1500 & $-20,8800$ & 7,0000 \\
\hline & & & & & & & $12: 28$ \\
\hline \multirow[t]{2}{*}{ 22/jun } & 3,7601 & 0,4309 & 3,7800 & $-0,5300$ & 3,7800 & $-20,9300$ & 7,0000 \\
\hline & & & & & & & $12: 28$ \\
\hline \multirow[t]{2}{*}{$23 /$ set } & 3,9389 & 0,6753 & 3,9500 & $-0,2800$ & 3,9500 & $-20,9800$ & 7,0000 \\
\hline & & & & & & & $13: 36$ \\
\hline 21/dez & 4,0739 & 0,8060 & 4,0800 & $-0,0015$ & 4,0800 & $-21,0300$ & 24,0000 \\
\hline
\end{tabular}

$\boldsymbol{\beta}$ - $\quad$ inclinação dos módulos com relação ao plano horizontal $24^{\circ}$

p - refletividade : $100 \%[44]$. 
Tabela 10 - Salvador, módulos instalados na horizontal.

\begin{tabular}{|c|c|c|c|c|c|c|c|}
\hline & \multirow{3}{*}{$\begin{array}{c}\mathrm{H}_{\mathrm{t}} \\
\left(\mathrm{kWh} / \mathrm{m}^{2}\right)\end{array}$} & \multirow{3}{*}{$\mathbf{R}_{\mathbf{b}}$} & \multirow{3}{*}{$\begin{array}{c}\mathbf{H}_{\mathbf{t}} \\
\text { Sundata }\end{array}$} & \multirow{3}{*}{$\begin{array}{l}\mathbf{H}_{\mathbf{t}}(\%) \\
\text { Planilha/ } \\
\text { Sundata }\end{array}$} & \multirow{3}{*}{$\mathbf{H}$} & \multirow[b]{2}{*}{$\alpha$} & \multirow[b]{2}{*}{$\omega$} \\
\hline & & & & & & & \\
\hline & & & & & & $\alpha\left[^{\circ}\right]$ & $\boldsymbol{\omega}\left[{ }^{\circ}\right]$ \\
\hline & & & & & & & $12: 28$ \\
\hline \multirow[t]{2}{*}{$21 / \mathrm{mar}$} & 5,4912 & 0,8318 & 5,5000 & $-0,1820$ & 5,5000 & $-23,3000$ & 7,0000 \\
\hline & & & & & & & $12: 28$ \\
\hline \multirow[t]{2}{*}{ 22/jun } & 3,5204 & 0,7202 & 3,5300 & $-0,2700$ & 3,5300 & $-23,3100$ & 7,0000 \\
\hline & & & & & & & $12: 28$ \\
\hline \multirow[t]{2}{*}{$23 /$ set } & 5,6610 & 0,8340 & 5,6700 & $-0,1760$ & 5,6700 & $-23,3100$ & 7,0000 \\
\hline & & & & & & & $13: 36$ \\
\hline 21/dez & 6,7434 & 0,8947 & 6,7500 & $-0,0900$ & 6,7500 & $-23,3300$ & 24,0000 \\
\hline
\end{tabular}

$\beta=$ inclinação dos módulos a $10^{\circ}$

$\rho=$ refletividade de $100 \%$

Tabela 11 - Salvador, módulos instalados a 13으, igual à latitude.

\begin{tabular}{|c|c|c|c|c|c|c|c|}
\hline & \multirow{3}{*}{$\begin{array}{c}\mathrm{H}_{\mathrm{t}} \\
\left(\mathrm{kWh} / \mathrm{m}^{2}\right)\end{array}$} & \multirow{3}{*}{$\mathbf{R}_{\mathrm{b}}$} & \multirow{3}{*}{$\begin{array}{c}\mathbf{H}_{\mathbf{t}} \\
\text { Sundata }\end{array}$} & \multirow{3}{*}{$\begin{array}{l}\mathbf{H}_{\mathbf{t}}(\%) \\
\text { Planilha/ } \\
\text { Sundata }\end{array}$} & \multirow{3}{*}{ H } & & \multirow[b]{2}{*}{$\omega$} \\
\hline & & & & & & $\alpha$ & \\
\hline & & & & & & $\alpha\left[^{\circ}\right]$ & $\omega\left[\left[^{\circ}\right]\right.$ \\
\hline & & & & & & & $12: 28$ \\
\hline \multirow[t]{2}{*}{ 21/mar } & 5,5197 & 0,8013 & 5,5300 & $-0,1900$ & 5,5300 & $-23,3000$ & 7,0000 \\
\hline & & & & & & & $12: 28$ \\
\hline \multirow[t]{2}{*}{ 22/jun } & 3,9272 & 0,6621 & 3,9400 & $-0,3200$ & 3,9400 & $-23,3100$ & 7,0000 \\
\hline & & & & & & & $12: 28$ \\
\hline \multirow[t]{2}{*}{ 23/set } & 5,8093 & 0,8040 & 5,8200 & $-0,1800$ & 5,8200 & $-23,3100$ & 7,0000 \\
\hline & & & & & & & $13: 36$ \\
\hline $21 / \mathrm{dez}$ & 6,1833 & 0,8788 & 6,1900 & $-0,1100$ & 6,1900 & $-23,3300$ & 24,0000 \\
\hline
\end{tabular}

$\beta=$ inclinação dos módulos a $13^{\circ}$

$\rho=$ refletividade de $100 \%$ 
Tabela 12 - Porto Alegre, módulos instalados na horizontal.

\begin{tabular}{|c|c|c|c|c|c|c|c|}
\hline & \multirow[t]{2}{*}{$\begin{array}{c}H_{t} \\
\left(k W h / m^{2}\right)\end{array}$} & \multirow[t]{2}{*}{$\mathbf{R}_{\mathrm{b}}$} & \multirow[t]{2}{*}{$\begin{array}{c}\mathbf{H}_{\mathrm{t}} \\
\text { Sundata }\end{array}$} & \multirow{2}{*}{$\begin{array}{c}\mathbf{H}_{\mathbf{t}}(\%) \\
\text { Planilha/ } \\
\text { Sundata }\end{array}$} & \multirow[t]{2}{*}{ H } & $\alpha$ & $\boldsymbol{\omega}$ \\
\hline & & & & & & $\alpha\left[^{\circ}\right]$ & $\boldsymbol{\omega}\left[{ }^{\circ}\right]$ \\
\hline & & & & & & & $12: 28$ \\
\hline $21 / \mathrm{mar}$ & 4,6594 & 0,7650 & 4,6700 & $-0,2270$ & 4,6700 & $-15,8500$ & 7,0000 \\
\hline & & & & & & & $12: 28$ \\
\hline 22/jun & 2,4110 & 0,6203 & 2,4200 & $-0,3770$ & 2,4200 & $-15,9000$ & 7,0000 \\
\hline & & & & & & & $12: 32$ \\
\hline $23 /$ set & 4,0708 & 0,7669 & 4,0800 & $-0,2280$ & 4,0800 & $-15,9300$ & 8,0000 \\
\hline & & & & & & & $14: 00$ \\
\hline 21/dez & 6,4906 & 0,8481 & 6,5000 & $-0,1440$ & 6,5000 & $-15,9600$ & 30,0000 \\
\hline
\end{tabular}

$\beta=$ inclinação dos módulos a $10^{\circ}$

$\rho=$ refletividade de $100 \%$

Tabela 13 - Porto Alegre, módulos instalados a 30ㅜㅡ, igual à latitude.

\begin{tabular}{|c|c|c|c|c|c|c|c|}
\hline & \multirow{3}{*}{$\begin{array}{c}H_{t} \\
\left(k W h / m^{2}\right)\end{array}$} & \multirow{3}{*}{$\mathbf{R}_{\mathbf{b}}$} & \multirow{3}{*}{$\begin{array}{c}\mathbf{H}_{\mathrm{t}} \\
\text { Sundata }\end{array}$} & \multirow{3}{*}{$\begin{array}{l}\mathbf{H}_{\mathbf{t}}(\%) \\
\text { Planilha/ } \\
\text { Sundata }\end{array}$} & \multirow{3}{*}{$\mathbf{H}$} & \multirow[b]{2}{*}{$\alpha$} & \multirow[b]{2}{*}{$\omega$} \\
\hline & & & & & & & \\
\hline & & & & & & $\alpha\left[^{\circ}\right]$ & $\omega\left[\left[^{\circ}\right]\right.$ \\
\hline & & & & & & & $12: 28$ \\
\hline \multirow[t]{2}{*}{$21 / \mathrm{mar}$} & 4,9184 & 0,4966 & 4,9400 & $-0,4300$ & 4,9400 & $-15,8500$ & 7,0000 \\
\hline & & & & & & & $12: 28$ \\
\hline \multirow[t]{2}{*}{ 22/jun } & 3,4331 & 0,1548 & 3,4600 & $-0,7800$ & 3,4600 & $-15,9000$ & 7,0000 \\
\hline & & & & & & & $12: 32$ \\
\hline \multirow[t]{2}{*}{$23 /$ set } & 4,4905 & 0,5005 & 4,5100 & $-0,4400$ & 4,5100 & $-15,9300$ & 8,0000 \\
\hline & & & & & & & $14: 00$ \\
\hline 21/dez & 5,6359 & 0,6839 & 5,6500 & $-0,2500$ & 5,6500 & $-15,9600$ & 30,0000 \\
\hline
\end{tabular}

$\beta=$ inclinação dos módulos a $30^{\circ}$

$\rho=$ refletividade de $100 \%$

$H_{t} \cdot \quad$ irradiação total diária na sup. inclinada

H - irradiação global média anual

w- ângulo do deslocamento do sol a leste ou oeste do meridiano
$\mathrm{Rb}$ - relação entre a irradiação direta sobre a sup. inclinada e a radiação sobre o plano horizontal

a- declinação $\quad \beta$ - inclinação dos módulos com relação ao plano horizontal

p. refletividade : $100 \%[44]$.

Sundata - [43] 
- validada a metodologia, calculamos a irradiação total mensal para o estudo de caso, item 4.1.1, com a instalação dos módulos a 90, gerando a tabela 14;

Tabela 14 - Irradiação total mensal para o estudo de caso com a instalação dos módulos à $90^{\circ}$.

\begin{tabular}{|c|c|c|c|c|c|}
\hline \multirow{3}{*}{2011} & \multirow{3}{*}{$\begin{array}{c}\mathrm{H}_{\mathrm{t}} \\
\left(\mathrm{kWh} / \mathrm{m}^{2}\right)\end{array}$} & \multirow{3}{*}{$\mathbf{R}_{\mathbf{b}}$} & \multirow{3}{*}{ H } & & \multirow[b]{2}{*}{$\omega$} \\
\hline & & & & $\alpha$ & \\
\hline & & & & $\alpha\left[^{\circ}\right]$ & $\omega\left[\left[^{\circ}\right]\right.$ \\
\hline Jan. & 70,9360 & $-0,1459$ & 4,5000 & $-20,8500$ & 24,0000 \\
\hline Fev. & 71,0180 & $-0,2661$ & 5,0000 & $-20,8500$ & 22,0000 \\
\hline Mar. & 63,5941 & $-0,4702$ & 4,0600 & $-20,8800$ & 22,0000 \\
\hline Abr. & 47,6586 & $-0,7226$ & 3,1600 & $-20,8800$ & 22,0000 \\
\hline Maio & 49,4669 & $-0,9826$ & 3,1900 & $-20,9100$ & 22,0000 \\
\hline Jun. & 43,9970 & $-1,1249$ & 2,9400 & $-20,9100$ & 22,0000 \\
\hline Jul. & 49,8599 & $-1,0574$ & 3,2200 & $-20,9500$ & 22,0000 \\
\hline Ago. & 57,8644 & $-0,8240$ & 3,7200 & $-20,9600$ & 22,0000 \\
\hline Set. & 56,7442 & $-0,5632$ & 3,7500 & $-20,9600$ & 22,0000 \\
\hline Out. & 63,3001 & $-0,3266$ & 4,0300 & $-20,1000$ & 22,0000 \\
\hline Nov. & 76,2332 & $-0,1749$ & 5,0000 & $-20,1000$ & 24,0000 \\
\hline Dez. & 71,4610 & $-0,1080$ & 4,5300 & $-21,0300$ & 24,0000 \\
\hline Total & 733,5879 & & & & \\
\hline
\end{tabular}

$\beta=$ inclinação dos módulos a $90^{\circ}$

$\rho=$ refletividade de $3,0 \%$ 


\subsection{CARACTERÍSTICA DA CÉLULA - MÓDULO SOLAR DE FILME FINO UTILIZADO}

O estudo em questão utiliza a tecnologia de painéis fotovoltaicos de filme fino, CIGS, item 2.3, Potência Máxima Forte 120 (Power Max® STRONG 120) fabricada pela AVANCIS [47]. Estes módulos, produzidos industrialmente foram concebidos para uso em sistemas panorâmicos, espaços abertos e ou como solução em cobertura de fachadas. Além disso, eles são resistentes à corrosão, poluição, tornando-os adequados para utilização em grandes centros urbanos e áreas costeiras. Alto rendimento, maior sensibilidade espectral, alto desempenho em condições de pouca luz, e o coeficiente de baixa temperatura garantem um rendimento de alta energia $(\mathrm{kWh} / \mathrm{kWp})$.

\subsubsection{Características elétricas da célula - módulo solar de filme fino utilizado}

Características elétricas dos módulos medidos sob condições de ensaio padrão, irradiância de $1000 \mathrm{~W} / \mathrm{m}^{2}$ no plano do módulo a temperatura de $25^{\circ} \mathrm{C}$ e uma distribuição espectral de luz solar de acordo com a massa atmosférica (AM) 1,5 (Figura 36). 


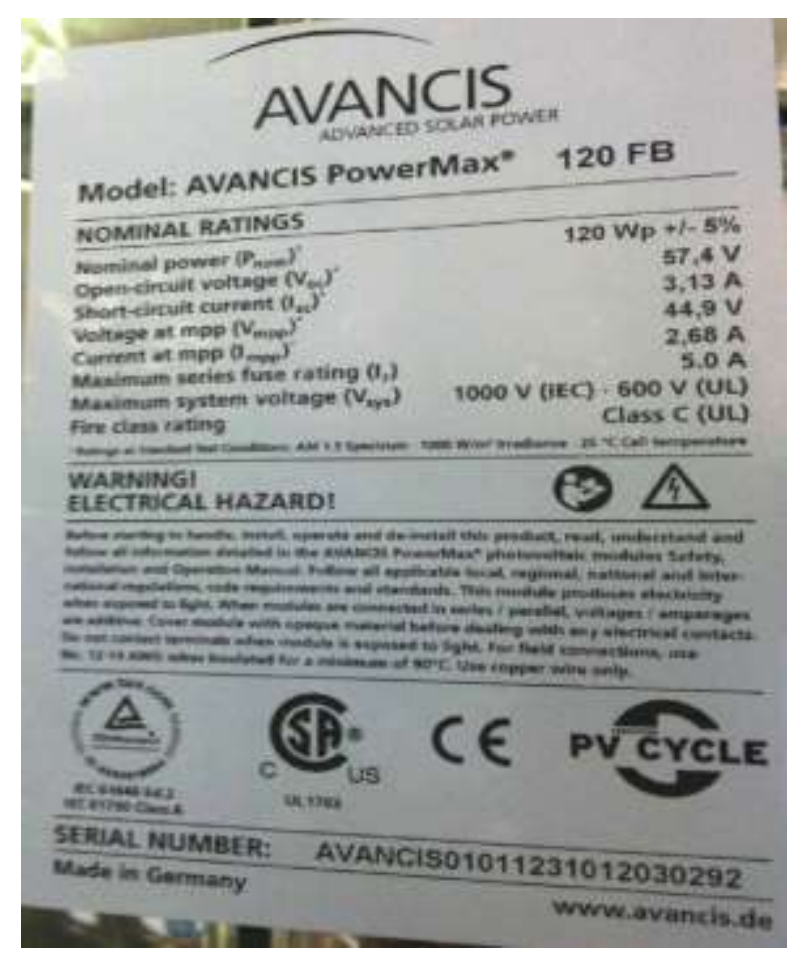

Figura 36 - Características elétricas dos módulos [9][48].

Potência nominal $P_{\text {nom }}=120 \mathrm{Wp}$

Tolerância da potência nominal $\Delta P_{\text {nom }}=+/-5 \%$

Eficiência do módulo $\eta=11,2 \%$

\section{Eficiência do módulo na posição vertical $\eta=4,5 \%{ }^{14}$}

Eficiência de abertura $\eta=12,7 \%$

Tensão com circuito aberto $\mathrm{V}_{\mathrm{oc}}=57,4 \mathrm{~V}$

Corrente de curto circuito $I_{\mathrm{sc}}=3,13 \mathrm{~A}$

Tensão a máxima potência $\mathrm{V}_{\mathrm{mpp}}=44,9 \mathrm{~V}$

Corrente a máxima potência $I_{m p p}=2,68 \mathrm{~A}$

Máxima corrente inversa $\mathrm{I}_{\mathrm{r}}=5 \mathrm{~A}$

Máxima tensão $\mathrm{V}_{\text {sys }}($ IEC) $=1000 \mathrm{~V}$

Máxima tensão $\mathrm{V}_{\text {sys }}(\mathrm{UL})=600 \mathrm{~V}$

Superfície geradora $=0,602 \times 1,583=0,95 \mathrm{~m}^{2}$

Superfície total considerada = sup. geradora + espaçamento de montagem $=1,065 \mathrm{~m}^{2}$

${ }^{14}$ Didier Jousse, Diretor de vendas América do Sul, Saint - Gobain Solar $\leq$ didier.Jousse@saintgobain.com> Acesso em 15 mar. 2013. 
Dados medidos à temperatura nominal de funcionamento da célula de $40^{\circ} \mathrm{C}$, irradiância de $800 \mathrm{~W} / \mathrm{m}^{2}$ no plano do modulo, temperatura do ar de $20^{\circ} \mathrm{C}$, velocidade do vento $1 \mathrm{~m} / \mathrm{s}$, condição de circuito aberto e a $\mathrm{AM}$ $1,5(45)$.

Potência nominal $P_{\text {nom }}=89,5 \mathrm{~W}$

Tensão com circuito aberto $V_{o c}=54,8 \mathrm{~V}$

Corrente de curto circuito $I_{s c}=2,51 \mathrm{~A}$

Tensão a máxima potência $\mathrm{V}_{\mathrm{mpp}}=39,9 \mathrm{~V}$

Redução da Potência nominal $P_{\text {nom }}=-0,39 \% / 0 \mathrm{C}$

Redução da Tensão com circuito aberto $V_{o c}=-170 \mathrm{mV} /{ }^{\circ} \mathrm{C}$

Redução da Corrente de curto circuito $I_{\mathrm{sc}}=0,1 \mathrm{~mA} /{ }^{\circ} \mathrm{C}$

Redução da Tensão a máxima potência $V_{\mathrm{mpp}}=-140 \mathrm{mV} /{ }^{\circ} \mathrm{C}$

Potência nominal considerada a $40^{\circ} \mathrm{C}=113 \mathrm{Wp}$

Dados medidos com baixa intensidade de luz:

- a redução de eficiência relativa no módulo a uma irradiância de $200 \mathrm{~W} / \mathrm{m}^{2}$ em relação a $1000 \mathrm{~W} / \mathrm{m}^{2}$, temperatura do módulo de $25^{\circ}$ C, AM 1,5 é de $10 \%$.

- a uma irradiância de $500 \mathrm{~W} / \mathrm{m}^{2}$ a redução de eficiência relativa do módulo é de $1 \%$. 


\subsection{EStimativa DO POTENCIAL DE GERAÇÃO COM A IMPLEMENTAÇÃO DOS MÓDULOS FV}

Para a estimativa do potencial de geração fotovoltaica utilizam-se os módulos especificados no item 4.3. Os módulos foram alocados nas áreas envidraçadas (AE), áreas disponíveis sem vidros (ADSV) e nas áreas totais das fachadas (AT), sempre montados à $90^{\circ}$, tabela 14 .

Com as áreas disponíveis para a integração de módulos, foi possível verificar o potencial de geração fotovoltaica. A maneira de se obter o potencial que poderá ser instalado é dispondo, na área disponível, os módulos fotovoltaicos de acordo com suas dimensões, deixando espaços para sua instalação e acessos para manutenção, quando se fizer necessário. Para $A E=528 \mathrm{~m}^{2}$ de superfície ocupada por módulos, da mesma forma para ADSV $=943 \mathrm{~m}^{2}$ e AT $=1.471 \mathrm{~m}^{2}$.

\subsubsection{Estimativa de geração fotovoltaica}

A partir de todos os dados coletados, foram calculados os valores de geração solar fotovoltaica de acordo com a equação 3.20.

$$
\mathrm{E}_{\mathrm{FV}}=\mathrm{H}_{\mathbf{t}} \times \eta_{\mathrm{FV}} \times \mathrm{A} \times \eta_{\mathrm{MPPT}}
$$

onde:

$\mathrm{E}_{\mathrm{FV}}=$ Geração solar fotovoltaica $(\mathrm{kWh})$.

$H_{t}=$ Irradiação total diária recebida no plano do módulo fotovoltaico $\left(\mathrm{kWh} / \mathrm{m}^{2}\right)$, tabela 14.

$\eta_{\mathrm{FV}}=$ eficiência do módulo fotovoltaico (\%), item 4.3.1.

$A$ = superfície ocupada pelos módulos fotovoltaicos $\left(\mathrm{m}^{2}\right)$, tabela 5 .

$\eta_{\text {MPPT }}=$ eficiência do sistema (controlador e inversor). Utiliza-se o valor 0,9 [37]. 
Geração $E_{\mathrm{FV}}(\mathrm{kWh})$ para AE, ADSV, AT para 2011 e irradiação solar incidente, estão apontados na tabela 15;

Tabela 15 - Estimativa de geração mensal de eletricidade e porcentagem do consumo suprido pelo sistema FV.

\begin{tabular}{|c|c|c|c|c|c|c|c|c|c|c|}
\hline Mês & Consumo & \multicolumn{2}{|c|}{ GS (kWh) (com sombras) } & \multicolumn{3}{|c|}{ CMC (\%) } & \multicolumn{3}{c|}{ GS (kWh) (sem sombras) } \\
\hline & $\mathbf{( k W h )}$ & AE & ADSV & AT & AE & ADSV & AT & AE & ADSV & AT \\
\hline Jan. & 6.320 & 1.516 & 2.709 & 4.226 & 23,9 & 42,8 & 67,5 & 1.970 & 3.521 & 5.493 \\
\hline Fev. & 6.160 & 1.518 & 2.712 & 4.230 & 24,6 & 44 & 68,6 & 1.973 & 3.525 & 5.499 \\
\hline Mar. & 6.600 & 1.359 & 2.427 & 3.787 & 20,5 & 36,7 & 57,3 & 1.766 & 3.155 & 4.923 \\
\hline Abr. & 6.960 & 1.019 & 1.820 & 2.839 & 14,6 & 36,7 & 40,7 & 1.324 & 3.148 & 3690 \\
\hline Maio & 7.120 & 1.057 & 1.889 & 2.946 & 14,8 & 26,5 & 41,3 & 1.374 & 2.455 & 3.829 \\
\hline Jun. & 7.680 & 940 & 1.680 & 2.620 & 12,2 & 21,8 & 34,1 & 1.222 & 2.184 & 3.406 \\
\hline Jul. & 7.680 & 1.066 & 1.904 & 2.970 & 13,8 & 24,7 & 38,6 & 1.385 & 2.475 & 3.861 \\
\hline Ago. & 7.920 & 1.237 & 2.209 & 3.446 & 15,6 & 27,8 & 43,5 & 1.608 & 2.871 & 4.479 \\
\hline Set. & 7.800 & 1.213 & 2.167 & 3.380 & 15,5 & 27,7 & 43,3 & 1.576 & 2.817 & 4.394 \\
\hline Out. & 8.040 & 1.353 & 2.417 & 3.770 & 16,8 & 30 & 46,9 & 1.758 & 3.142 & 4.901 \\
\hline Nov. & 7.360 & 1.630 & 2.911 & 4.541 & 22,1 & 39,5 & 61,7 & 2.119 & 3.784 & 5.903 \\
\hline Dez. & 7.240 & 1.528 & 2.729 & 4.257 & 21,2 & 37,6 & 58,8 & 1.986 & 3.547 & 5.534 \\
\hline Anual & $\mathbf{8 6 . 8 8 0}$ & $\mathbf{1 5 . 4 3 6}$ & $\mathbf{2 7 . 5 7 4}$ & $\mathbf{4 3 . 0 1 2}$ & $\mathbf{1 7 , 9}$ & $\mathbf{3 2 , 9}$ & $\mathbf{5 0 , 1}$ & $\mathbf{2 0 . 0 6 1}$ & $\mathbf{3 5 . 8 4 6}$ & $\mathbf{5 5 . 9 1 2}$ \\
\hline
\end{tabular}

GS - geração solar, CMC - contribuição mensal ao consumo.

$E_{\mathrm{FV}}$ média mensal e anual para $\mathrm{AE}=1,286 \mathrm{MWh} /$ mês e $15,436 \mathrm{MWh} / \mathrm{ano}$

$\mathrm{E}_{\mathrm{FV}}$ média mensal e anual para ADSV = 2,297 MWh/mês e 27,574 MWh/ano

$E_{\mathrm{FV}}$ média mensal e anual para AT $=3,584 \mathrm{MWh} / \mathrm{mês}$ e 43,012 MWh/ano

Na simulação a contribuição da geração solar com sombras ao consumo mensal no envelope total do prédio (AT), apresenta valores entre $34 \%$ e $68 \%$ ao mês com valor médio anual de aproximadamente $50 \%$.

\subsubsection{Contribuição da geração fotovoltaica na redução do consumo de} energia elétrica proveniente da rede pública

A partir dos dados coletados nas faturas de energia elétrica do prédio, no período estudado, foi possível avaliar o consumo médio mensal de 7,24 MWh/mês. Este dado foi comparado com a capacidade estimada média mensal de geração do sistema fotovoltaico. Conforme pode ser visto na geração média mensal FV a capaci- 
dade de geração para $A E=1,286 \mathrm{MWh} /$ mês, $\mathrm{ADSV}=2,297 \mathrm{MWh} / \mathrm{mês}$ é para $\mathrm{AT}=$ 3,584 MWh/mês são valores inferiores ao consumo médio mensal do prédio, portanto esta energia poderia ser integralmente utilizada pelo próprio prédio.

Considerando que o custo médio do MWh, incluindo distribuição, transmissão, encargos e tributos, para o período em estudo foi de $R \$ 390,00 / \mathrm{MWh}$ [51], com o montante gerado na $A E, A D S V$ e $A T$, teríamos uma redução mensal de $R \$ 501,00$, $R \$ 896,00$ e $R \$ 1.398,00$ respectivamente.

Podemos dizer que com a instalação da geração fotovoltaica no envelope total do prédio (AT), deixaríamos de pagar anualmente aproximadamente $R \$ 16.775,00$.

A Resolução da Agência Nacional de Energia Elétrica (ANEEL) n 482/2012 já regulamenta a conexão de microgeradores à rede de distribuição, com a possibilidade de "vender" a energia excedente usando um sistema de compensação entre a distribuidora e o consumidor. Esta compensação ocorreria por posto tarifário, isto é, a tarifa usada para remunerar a energia excedente dependeria do horário em que fosse gerada.

Como a energia solar fotovoltaica seria complementar ao regime de chuvas, sua maior utilização propiciaria um ganho adicional ao seu usuário que obteria mais energia autogerada exatamente nos meses de tarifa mais alta. Além disso, permitiria ainda um ganho a todo o sistema, por reduzir a demanda agregada nos meses de maior custo de geração.

A princípio, meses com maior nebulosidade reduziriam a geração fotovoltaica. Nestes meses, em contrapartida, haveria também maior incidência de chuvas, abastecendo os reservatórios das hidrelétricas e reduzindo o custo de energia do sistema elétrico nacional (menor necessidade de se ligarem as térmicas, cujo custo variável de operação é maior). Nos meses mais secos, haveria maior geração fotovoltaica, compensando, em parte, uma menor geração hidrelétrica. Assim, a energia solar fotovoltaica seria naturalmente complementar à principal fonte da matriz elétrica brasileira, a energia hidráulica. 
Mesmo que a energia injetada seja superior à consumida no posto tarifário em questão, a Resolução ANEEL n 482/2012 prevê que ela pode ser compensada em outros postos tarifários, sendo "observada a relação entre os valores das tarifas de energia, se houver" (ANEEL, 2012, Artigo $7^{\circ}$, inciso III). Assim, a Resolução ANEEL $n^{\circ} 482 / 2012$ considera que a energia fotovoltaica - ou qualquer outra obtida de microgeração distribuída - injetada na distribuidora será remunerada considerando as tarifas por posto tarifário, que a princípio indicam o custo de operação e expansão do sistema elétrico em função da variação do consumo dentro do dia.

\subsubsection{Contribuição da geração fotovoltaica na redução da emissão de gás $\mathrm{CO}_{2}$ (monóxido de carbono).}

4.4.3.1 Quantidade de $\mathrm{CO}_{2}$ liberados na atmosfera para produzir $1 \mathrm{kWh}$ no Brasil.

A produção de um kWh de eletricidade se faz usando diferentes fontes de energia, caracterizadas por um fator que indica quantos quilos de $\mathrm{CO}_{2}$ são liberados na atmosfera para produzir $1 \mathrm{kWh}$ de eletricidade que são mudanças que dependem do tipo e eficiência da fonte geradora e da rede de distribuição.

Algumas das fontes de energia são petróleo, gás natural, carvão, resíduos sólidos urbanos (energia térmica), urânio enriquecido (nuclear), gradientes de água (hidrelétricas), calor da terra (geotérmica),energia eólica (vento), solar (fotovoltaica e térmica), biomassa, etc.

Cada nação tem diversas usinas que utilizam fontes de energia diferentes, então o valor de $\mathrm{kg} \mathrm{CO}_{2}$ / kWh será diferente para cada país, esse fator pode ser usado para calcular as emissões no ambiente de $\mathrm{CO}_{2}$ evitadas no país onde a geração $\mathrm{FV}$ está instalada. No Brasil o fator é de $86,7654\left(\mathrm{gCO}_{2} / \mathrm{kWhel}\right)$ Fonte: International Energy Agency (IEA),2010. 
4.4.3.2 Quantidade de $\mathrm{CO}_{2}$ liberados na atmosfera durante o ciclo de vida de uma célula FV de filme fino ( CIGS).

O sistema fotovoltaico considerado compreende os módulos conectados à rede e o equilíbrio do sistema, que inclui cabos, inversores e estruturas de apoio para os módulos. O equilíbrio do sistema assume uma forma diferente em termos de quantidade de equipamentos e materiais para instalações a nível do piso, telhados e fachadas. Sistemas montados em fachadas ou com rastreamento do sol não foram incluídos neste estudo. O ciclo de vida do filme fino( CIGS) começa com a aquisição de matérias primas, engloba materiais de produção, deposição de filmes, produção do módulo, montagem do sistema, operação do sistema e termina com a sua eliminação. Note-se que a fase de reciclagem do ciclo de vida de película fina não foi incluído no presente estudo, uma vez que é relativamente nova nas instalações.

Nas instalações FV com filmes finos (CIGS), estudos ambientais do ciclo de vida FV mostram a emissão de gases do efeito estufa na tabela 16.

Tabela 16 Emissões de $\mathrm{CO}_{2}$ nas instalações $\mathrm{FV}$ com filmes finos (CIGS) [52].

\begin{tabular}{|l|c|c|c|c|c|c|}
\hline $\begin{array}{l}\text { Autor do } \\
\text { estudo }\end{array}$ & $\begin{array}{c}\text { Emissão } \\
\left(\mathrm{gCO}_{2-}\right. \\
\text { eq./kWh })\end{array}$ & $\begin{array}{c}\text { Irradiação } \\
\text { solar média } \\
\text { anual } \\
\left(\mathrm{kWh} / \mathrm{m}^{2} / \mathrm{ano}\right)\end{array}$ & $\begin{array}{c}\text { Eficiência } \\
\text { do } \\
\text { módulo } \\
\mathrm{em} \%\end{array}$ & $\begin{array}{c}\text { Vida } \\
\mathrm{em} \\
\text { anos }\end{array}$ & $\begin{array}{c}\text { Tipo de } \\
\text { montagem }\end{array}$ & Nota \\
\hline $\begin{array}{c}\text { Domínguez } \\
\text { Ramos et } \\
\text { al.(2010) }\end{array}$ & 33 & 1,825 & 10 & 30 & No piso & $\begin{array}{c}\text { Produzido na Alema- } \\
\text { nha e instalado na } \\
\text { Espanha }\end{array}$ \\
\hline
\end{tabular}

Adotamos os valores da tabela 16 para obter uma estimativa de redução de gás $\mathrm{CO}_{2}$, embora a irradiação solar média anual no Brasil varie de 4.200 á 6.700 $\mathrm{kWh} / \mathrm{m}^{2}$-ano. 
Para obter uma estimativa de quantidades de $\mathrm{CO}_{2}$ liberado pelas duas fontes no estudo de caso, item 4.4.1, usamos os dados do fator Brasil e da tabela 16 nos cálculos apresentados na tabela 17.

Tabela 17 - Quantidades de $\mathrm{CO}_{2}$ liberado

\begin{tabular}{|c|c|c|c|c|}
\hline & $\begin{array}{c}\text { Emissão } \\
\left(\mathrm{gCO}_{2} \text { eq./kWh }\right)\end{array}$ & $\begin{array}{c}\text { GS - AT } \\
\text { MWh/ano } \\
(\text { Tab.10 })\end{array}$ & $\begin{array}{c}\text { Vida } \\
(\mathrm{em} \\
\text { anos })\end{array}$ & $\begin{array}{c}\text { Ton. } \\
\left(\mathrm{CO}_{2} / \mathrm{kWh}\right)\end{array}$ \\
\hline $\begin{array}{c}\text { Fator } \\
\text { Brasil }\end{array}$ & 86,7654 & 43,0120 & 30 & 111,9600 \\
\hline CIGS & 33,0000 & 43,0120 & 30 & 42,5800 \\
\hline
\end{tabular}

A partir dos dados coletados na tabela 12, foi calculado a redução da emissão de $\mathrm{CO}_{2}$ entre a geração no Brasil e a emissão com a geração $\mathrm{FV}$ subtraindo de 111,9600 toneladas de $\mathrm{CO}_{2} / \mathrm{kWh}$ em 30 anos o valor de 42,5800 toneladas de $\mathrm{CO}_{2} / \mathrm{kWh}$ em 30 anos resultando na redução de emissão de $\mathrm{CO}_{2} \approx 69.380$ $\mathrm{kgCO}_{2} / \mathrm{kWh}$-30anos ou $\approx 2.313 \mathrm{kgCO}_{2} / \mathrm{kWh}$-ano

\subsection{CONCLUSÕES}

A geração FV sugerida neste estudo conseguiria gerar energia o suficiente para alimentar todo o consumo do edifício e ser considerada uma alternativa de geração comercialmente viável, embora o seja tecnicamente.

Este estudo de caso considera as superfícies - fachadas como perpendiculares levando em consideração as questões reais do prédio: sombreamento, orientação e disponibilidade de espaço para montagem dos módulos FV. 
A radiação total incidente sobre uma superfície $F V$, conjugada com as características dos módulos FV, do sistema inversor, controlador e instalação, determinam a quantidade de energia disponível para a utilização no prédio.

Neste ponto, serão apresentados os resultados obtidos para a produção fotovoltaica anual para a tecnologia em estudo: filmes finos, item 4.3.1. Convêm referir que as eficiências utilizadas dizem respeito às condições de teste do fabricante, designadas de Standard Test Conditions (STC), sendo que na realidade as temperaturas descritas estão na média das verificadas neste estudo. Como se pretende uma estimativa da geração FV para o tipo de tecnologia escolhida, no modelo aplicado se efetua uma correção na potência nominal dos módulos FV, devido à influência da temperatura de funcionamento da célula de $40^{\circ} \mathrm{C}$ e na eficiência do módulo na montagem vertical. A estimativa de geração fotovoltaica foi calculada considerando os passos descritos no modelo do capítulo 3 .

Avaliando os resultados do modelo aplicado ao estudo de caso, item 4.1, em sistemas FV conectados à rede e instalados nas fachadas de um edifício, envelope (AT), chegamos aos seguintes custos dos componentes, tabela 18.

Tabela 18 - Custos dos componentes.

\begin{tabular}{|c|c|c|c|c|}
\hline Equipamento & $\begin{array}{c}\text { Quanti- } \\
\text { dade }\end{array}$ & $\begin{array}{c}\text { Preço } \\
\text { Unitário } \\
\mathrm{R} \$\end{array}$ & $\begin{array}{c}\text { Subtotal } \\
\mathrm{R} \$\end{array}$ & Fonte \\
\hline Módulo & 1380 & 820,00 & $1.131 .600,00$ & $\begin{array}{c}\text { Donauer Solar do } \\
\text { Brasil Ltda. } \\
\text { [Nowak,Marco, } \\
\text { 03/2013] }\end{array}$ \\
\hline Inversor estimado de 166 kW & 1 & $69.720,00$ & $69.720,00$ & $\begin{array}{c}\text { III Workshop inova FV } \\
\text { [Zilles,03/2013 ] }\end{array}$ \\
\hline Instalação: & & $3,25 / \mathrm{Wp}$ & $539.500,00$ & Abinee,2012 \\
\hline Total: & & & $\mathbf{1 . 7 4 0 . 8 2 0 , 0 0}$ & \\
\hline
\end{tabular}

Ou seja, $R \$ / k W 10.487,00$, valor $40 \%$ mais caro do que aquisições de células c-Si, R\$/kW 7.500,00 [Zilles,03/2013 ]. 
Considerando que para a instalação $\mathrm{FV}$, deixaríamos de pagar no ano $\mathrm{R} \$$ $16.775,00$ o retorno do investimento simples seria de 104 anos. Portanto, o montante em espécie necessário para a instalação FV é um valor economicamente inviável o que desestimula a instalação dos módulos, item 4.3.1 nas fachadas do prédio em estudo

Neste estudo foi constatado que a geração FV, nas condições propostas não é viável tecnicamente, porque não consegue alimentar todo o consumo e inviável economicamente por ter um tempo de retorno do investimento muito demorado.

No estudo da redução de emissão de gás $\mathrm{CO}_{2}$ os resultados obtidos são tecnicamente viáveis com a geração média $\left(\mathrm{E}_{\mathrm{FV}}\right)$ mensal para AT de 3,584 $\mathrm{MWh} / \mathrm{mês} 0$ que evitariam o plantio de 12 árvores por mês e de 4.320 árvores nos 30 anos de vida do sistema FV [53]. 


\section{CONSIDERAÇÕES FINAIS}

\subsection{ANÁLISE}

A metodologia aplicada no exemplo prático permitiu estimar a geração em uma superfície vertical de um sistema FV, com orientação, inclinação, sombreamento e suas condicionantes. Os resultados obtidos permitiram concluir que, nestas circunstâncias, a geração FV deixa a desejar, podendo mesmo existir reduções de aproximadamente $70 \%$ nas fachadas verticais.

Constatou-se que a orientação dos módulos do sistema FV integrado num edifício é uma limitação extremamente importante e com implicações na geração, apresentando sombreamentos naturais devido à trajetória do Sol e outros tipos de obstáculos. Em determinadas horas do dia estes sombreamentos resultam numa diminuição da geração FV no sistema BIPV.

Os ângulos de incidência solar são determinantes na radiação da superfície FV e na quantidade de energia gerada. No caso das fachadas verticais, não sendo a inclinação ideal em termos de produção anual, tal condicionante tem consequências a nível da geração FV.

A análise de sombreamentos neste tipo de metodologia é fundamental, as sombras provocadas pelos edifícios vizinhos ou por outro tipo de obstáculo mapeados na representação, influenciam a radiação. As realizações da análise de sombreamentos permitem definir áreas do próprio edifício onde são menos interessantes para a instalação de sistemas BIPV. 


\subsection{CONCLUSÕES}

A maior contribuição do modelo estudado deste sistema FV é a redução do consumo de energia elétrica da concessionária e a redução na emissão de gás $\mathrm{CO}_{2}$.

O presente estudo permite que sejam feitas análises do potencial de geração de energia FV para qualquer região do Brasil ou outro país. Sugere-se que esta metodologia seja aplicada em capitais brasileiras, com o objetivo de verificar o potencial energético das diferentes regiões do país, principalmente na região nordeste, onde há uma maior incidência solar. Para que seja realizado um estudo preciso, é necessário que seja desenvolvido uma metodologia de estimativa para quantificar o total anual de sombreamento de um setor para cada hora do dia, pois a cada instante, a radiação solar varia significativamente.

A metodologia desenvolvida poderia ser aplicada em edifícios do poder público, principalmente do Distrito Federal que apresentam menos sombreamento em relação ao prédio estudado em São Paulo. Estes edifícios, pelo fato de serem ocupados durante o dia, apresentam um pico de consumo diurno e são grandes consumidoras de energia elétrica. Desta forma, seria possível verificar o quanto de energia FV seria necessário para suprir esse consumo e os benefícios adquiridos pela concessionária local.

Atualmente, o custo da energia gerada pelos sistemas FV é alto em relação aos praticados pelas formas convencionais de geração de eletricidade, tabela 1 .

O objetivo deste trabalho é apontar as possíveis vantagens de utilizar uma energia renovável, silenciosa e favorável ao meio ambiente com o intuito de garantir a sustentabilidade do planeta. 


\subsection{TRABALHOS FUTUROS}

A metodologia apresentada neste estudo pode ser aplicada a qualquer edifício, desde que, se tenha os dados de consumo, suas características físicas e localização.

Contudo, alguns assuntos abordados devem ser pesquisados, de forma a se obter um maior detalhamento, a saber:

1. Uma análise do sombreamento nas fachadas do prédio, gerando dados precisos para estimar a geração $\mathrm{FV}$;

2. Instalação dos módulos, item 4.3.1, nas quatro fachadas do prédio estudado com monitoramento em diferentes épocas do ano e suas características elétricas, de temperatura e de geração de energia;

3. Avaliar qual é a melhor altura de instalação dos módulos para mais eficiência;

4. Quantificar os custos postergados de geração, expansão e distribuição.

Com as informações obtidas nos itens acima, proponho:

- Aplicar a metodologia num software que possibilite a estimativa de geração de energia elétrica especifica para edifícios;

- Avaliar os edifícios com potencial de geração fotovoltaica acima do consumo diurno, podendo exportar o excedente desta energia, para a concessionária e quantificar o impacto dessa geração nos alimentadores. 


\section{REFERÊNCIAS}

[1] Balanço Energético Nacional, ano base 2010. Disponível em: <https://been.epe.gov.br>. Acesso em: 02 de jun. 2011.

[2] Current Population Reports- Population Proyections of the United States by Age,Sex,Race,and hispanic Origin:1995 to 2050. Disponível em: <http://www.census.gov/prod/1/pop/p25-1130/p251130a.pdf>. Acesso em: 10 de jul. 2011.

[3] ANEEL. RESOLUÇÃO NORMATIVA № 482, DE 17 DE ABRIL DE 2012. Estabelece as condições gerais para o acesso de microgeração e minigeração distribuída aos sistemas de distribuição de energia elétrica, o sistema de compensação de energia elétrica, e dá outras providências. Disponível em: <http://www.aneel.gov.br/cedoc/ren2012482.pdf>. Acesso em: 10 de jul. 2011.

[4] Balanço Energético Nacional, ano base, 2012, Síntese do relatório final, ano base 2011.p.48. Disponível em: <https://ben.epe.gov.br/BENRelatorioFinal2012.aspx>. Acesso em:14 de mar. 2013.

[5] Grupo de Pesquisa Estratégica em Energia Solar da Universidade Federal de Santa Catarina - FOTOVOLTAICA-UFSC, ou FV-UFSC Disponível em: <http://www.fotovoltaica.ufsc.br/sobre>. Acesso em: 02 ago. 2011.

[6] MAURUS, $\mathrm{H}$. et al. PV for buildings: benefits and experiences with amorphous silicon in BIPV applications, Refocus, p.22-27, dez. 2004. Disponível em: <http://www.cubasolar.cu/biblioteca/Ecosolar/.../Articulo03N.html>. Acesso em: 15 de jun. 2011.

[7] CRADICK, K., Photovoltaics in buildings: town planning considerations. Energy Technology Support Unit, [Unknown Binding]: Amazon, CO.UK, 1999. 
[8] Instituto Superior Técnico. Energia fotovoltaica - manual sobre tecnologias, projeto e instalação, Janeiro de 2004. Disponível em: <https://dspace.ist.utl.pt>. Acesso em: 01 jan. 2011.

[9] Data sheet_PowerMax STRONG_2012_03_EN. Disponível em: <http://www.avancis.de>. Acesso em: 17 abr. 2012.

[10] Disponível em: <http://www.epe.gov.br>. Acesso em: 20 de jul. 2011.

[11] BENNER, J. P.; KAZMERSKI, L. Photovoltaics gaining greater visibility, I IEEE Spectrum, v.36, n.9, 1999.

[12] Sala de imprensa, "Empresa usa telhado para transformar energia solar em elétrica". 16/02/2011. Disponível em: <http://www.eletrosul.gov.br>. Acesso em: 29 abr. 2012.

[13] Experiência Edifício Zero Energia Exemplar Baseado no Solar Estate Solarsiedlung Freiburg am Schlierberg, Alemanha. Mira Heinze e Karsten Voss. Jornal do Green Building Nov 2009, vol. 4, n 4 (Fall 2009) pp 93-100. Disponível em: <http://journalofgreenbuilding.com>. Acesso em: 19 mai. 2012.

[14] Energia fotovoltaica - manual sobre tecnologias, projeto e instalação, 2004 Disponível em <http://www.greenpro.de/po/fotovoltaico.pdf>. Acesso em: 21 mai. 2011.

[15] SALAMONI, I.; RUTHER, R. Sistema fotovoltaico integrado a edificação e interligado a rede elétrica: eficiência energética e sustentabilidade. Universidade Federal de Santa Catarina, 2003. Disponível em: <http://www.labeee.ufsc.br>. Acesso em: 5 jan.2012.

[16] WAGNER,S. Thin Film CUINSE2/CDS Heterojunction Solar Cells, the fabrication and characteristics of CUINS2 Thin Film Homojunction Solar Cells are presented. Disponível em: Http://apl.aip.org Acesso em: 15 jan. 2012. 
[17] GOETZBERGER, A. et al. Photovoltaic materials, history, status and outlook. Materials Science and Engineering, p.1- 46, 2003.

[18] STRONG, S. Building integrated photovoltaics (BIPV), WBDG, 2008. Disponível em: <http://www.wbdg.org/resources/bipv.php>. Acesso em: 05 de jan.2010.

[19] CRESEB. Energia solar princípios e aplicações. Centro de Referencia para Energia Solar e Eólica Sérgio de Salvo Brito. Disponível em: <http://paje.fe.usp.br/ mef-pietro/mef2/app.upload/7/_mefmi_003-05.pdf>. Acesso em: 05 jan. 2010.

[20] DE Carlson e CR Wronski, Appl Peas Lett v. 28, p. 671, 1976. Disponível em: <http://run.unl.pt/bitstream/10362/2048/1/gomes_2009.pdf>. Acesso em: 05 de jan.2010.

[21] Markvart, T. Electricidade Solar. $2 \stackrel{a}{ }$ ed. Wiley, 2001.

[22] SCHOCK, H. W.; SHAH, A. In: Proceedings Europeu de Energia Solar PV Conferência de Barcelona, 14. 1997, p. 2000. Disponível em: <http://sciencedirect.com/science/article>. Acesso em: 20 ago 2011.

[23] WERNER, J.H., Inhomogene $\mathrm{Cu}(\mathrm{In}, \mathrm{Ga}) \mathrm{Se}_{2}$ Solarzellen. Institut für Physikalische Elektronik der Universität Stuttgart, 2007. Disponível em: <http://elib.unistuttgart.de/opus/volltexte/2007/3246/pdf/inhomogene_CIGS_Solar zellen_Grabitz_Dissertation.pdf>. Acesso em: 05 de jan.2010.

[24] Oswald, G. J. A indústria do PV se movendo para o século solar. In: Procedimento da Conferência Mundial sobre Conversão de Energia Solar Fotovoltaica, Viena, 1998.

[25] The University of Delaware's Institute of Energy Conversion (IEC), Estados Unidos da America. September 27, 2011 
[26] Pereira, L. S. (17 de fevereiro de 2010). Dopagem eletrônica. Info educação. Disponível em: <http://www.infoescola.com/quimica/dopagem-eletronica>. Acesso em: 13 de jan.2012.

[27] EMPA. Disponível em: <http://www.empa.ch/plugin/template/empa/*/107468>. Acesso em: 20 ago. 2011.

[28] QUASCHNING, V. Understanding renewable energy systems. Earthscan, 2005, p. 53.

[29] SURI, M.; HOFIERKA, J. A new GIS-based solar radiation model and its application to photovoltaic assessments. Blackwell Publishing, 2004.

[30] PRADO, R. T. A. et al. Levantamento do estado da arte: energia solar documento 2.3. Projeto Finep 2386/04, São Paulo, 2007.

[31] LORENZO, E. Radiação solar e dispositivos fotovoltaicos. Progensa, v. 2, 2006.

[32] DUFFIE, J. A.; BECKMAN, W. A. Solar engineering of thermal processes. Estados Unidos: John Wiley and Sons, maio de 2001.

[33] LOPEZ, R. D.; AGUSTIN, J. L. B. Curso interactivo de energia solar fotovoltaica. Zaragosa: Prensas Universitarias de Zaragoza, 2005.

[34] COLLARES-PEREIRA, M.; RABL, A. The average distribution of solar radiationcorrelations between diffuse and hemispherical and between daily and hourly insolation values. Solar Energy, p. 155-164, 1979.

[35] ZAKSEK, K. et al. Solar radiation modelling. Eslovenia: Elsevier, setembro de 2004. 
[36] SALAMONI, I.; RUTHER, R. O potencial dos sistemas fotovoltaicos integrados a edificação e interligados a rede elétrica em centros urbanos do Brasil: dois estudos de caso. São Paulo, Julho de 2004.

[37] ZILLES, R.[ET AL.]. Sistemas Fotovoltaicos conectados à rede elétrica. São Paulo, 2012, p. 78-95, 2012.

[38] NOGUCHI, T.; MATSUMOTO, H. Maximum-power-point tracking method of photovoltaic using only single current sensor. Nagoaka: Nagoaka University of Technology, p.54-55, 2003.

[39] JIANG, J. et al. Maximum power tracking for photovoltaic power systems. Tamkang Journal of Science and Engineering, v. 8, n. 2, p. 147-15, 2005.

[40] OLGYAY,Victor. Arquitectura y clima: manual de diseño bioclimático para arquitectos y urbanistas. Barcelona: Gustavo Gili, 1998.

[41] ESRI - GIS and mapping software. Disponível em:<http://www.esri.com/>. Acesso em: 5 jan. 2009.

[42] Disponível em: <http://www.on.br/mapa_site.html>. Acesso em: 20 ago. 2011.

[43] Disponível em: <http://www.cresesb.cepel.br/sundata/index.php>. Acesso em: 20 ago. 2011

[44] BYH, L.; Jordan, R. C. Daily insolation on surfaces tilted towards the equator. Trans ASHRAE, v. 67, p. 526-41, 1962.

[45] Klein, S. A. Calculation of monthly average insolation on tilted surfaces. Solar Energy, v. 19, p. 325, 1977.

[46] Disponível em: <http://www.google.com/earth/download/ge/> Acesso em: 21 abr. 2012. 
[47] AVANCIS GmbH \& Co. KG,Solarstrasse 3, 04860 Torgau, Germany .Disponível em : <http://www.avancis.de>.. Acesso em: 17 abr. 2012.

[48] Saint-Gobain Solar do Brasil- SHOWROOM: Saint-Gobain Euroveder, <http://www.saint-gobain-solar.com>, representante www.avancis.de

[49] Disponível em: <http://spacemath.gsfc.nasa.gov>. Acesso em: 21 set. 2012.

[50] Disponível em: <http://www.sunearthtools.com/dp/tools/pos_sun.php?lang=pt>. Acesso em 6 e 7 out. 2012.

[51] Tarifas de energia elétrica. Disponível em: $<$ https://www.aeseletropaulo.com.br/para-sua-casa/prazos-e tarifas/conteudo/tarifa-de-energia-eletrica>. Acesso em: 18 de mar.2013.

[52] Dominguez-Ramos, A., M. Held, R. Aldaco, M. Fischer, and A. Irabien. 2010. Prospective $\mathrm{CO}_{2}$ emissions from energy supplying systems: Photovoltaic systems and conventional grid within Spanish frame conditions. International Journal of Life Cycle Assessment 15(6): 557-566.

[53] Referências do estudo para base do cálculo de árvores: Lacerda, Jeanicolau Simone; Couto, H. T. Zarate; Pasishnyk, Natalia. Estimativa da biomassa de carbono em áreas restauradas com o plantio de essências nativas. Disponível <http://cmq.esalq.usp.br/wiki/doku.php?id=publico:metrvm:start>.. Acesso em: 14 de abril.2013. 
Anexos 


\section{ANEXO 1}

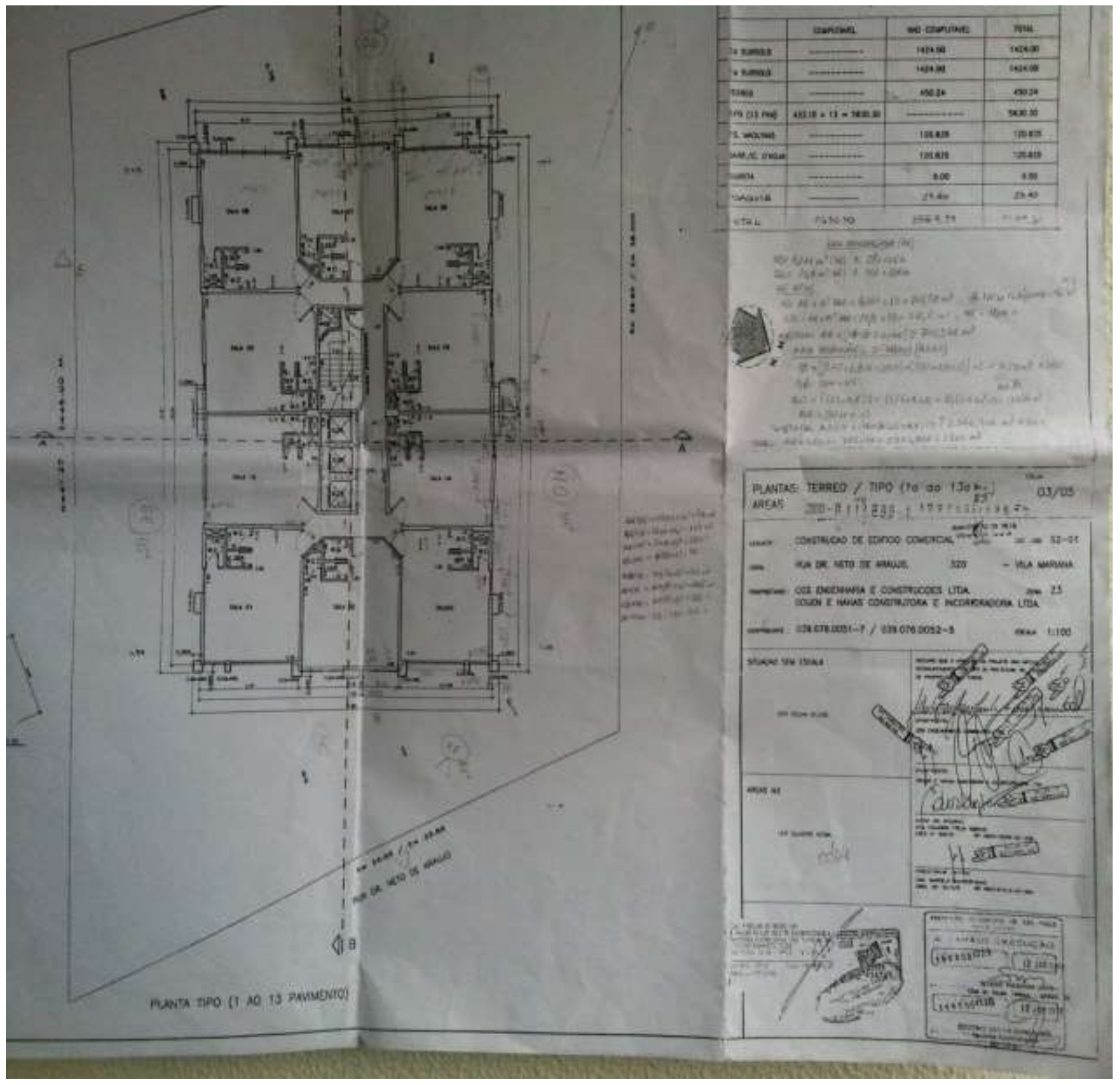

Planta 


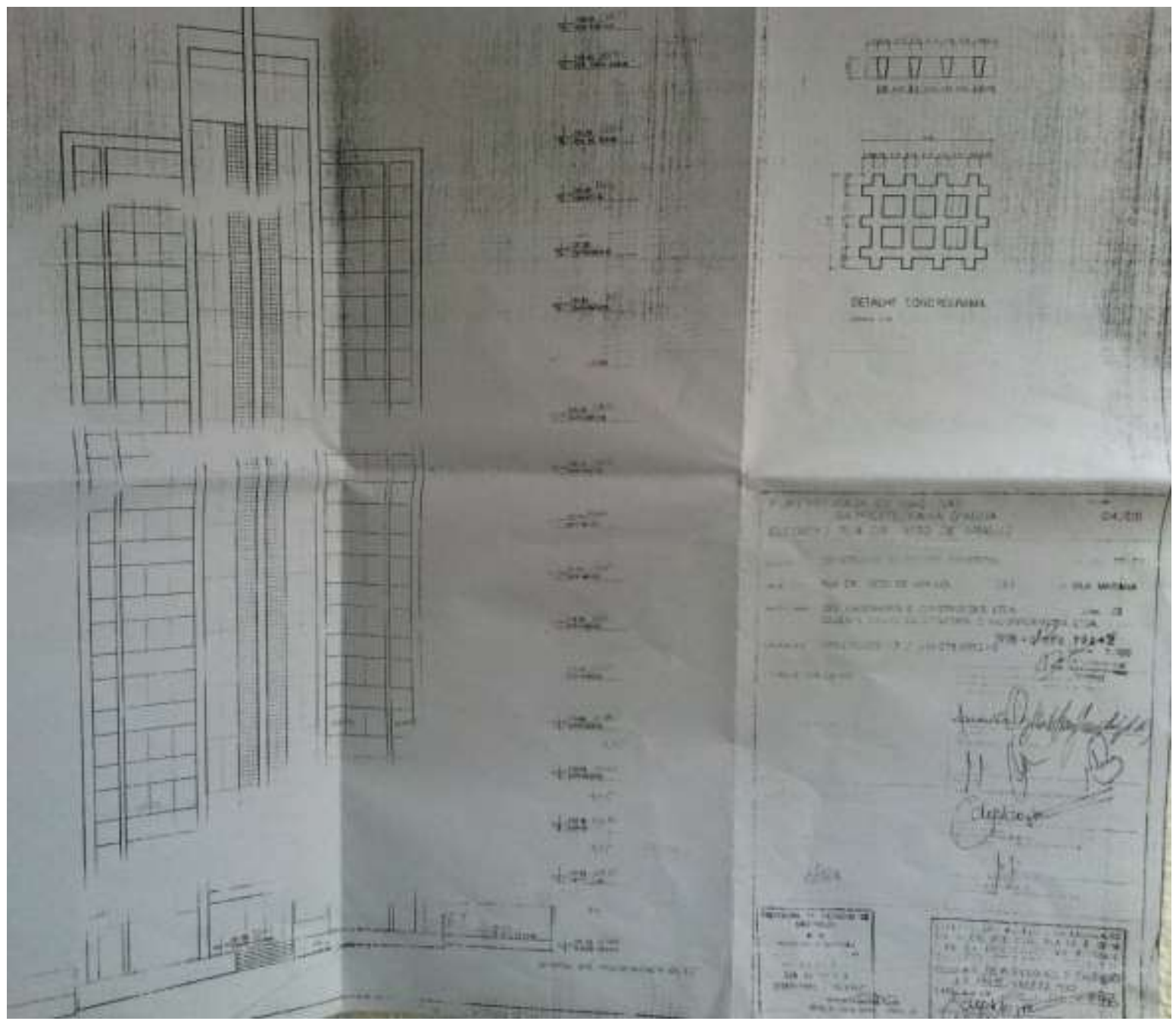

Vista Frontal 


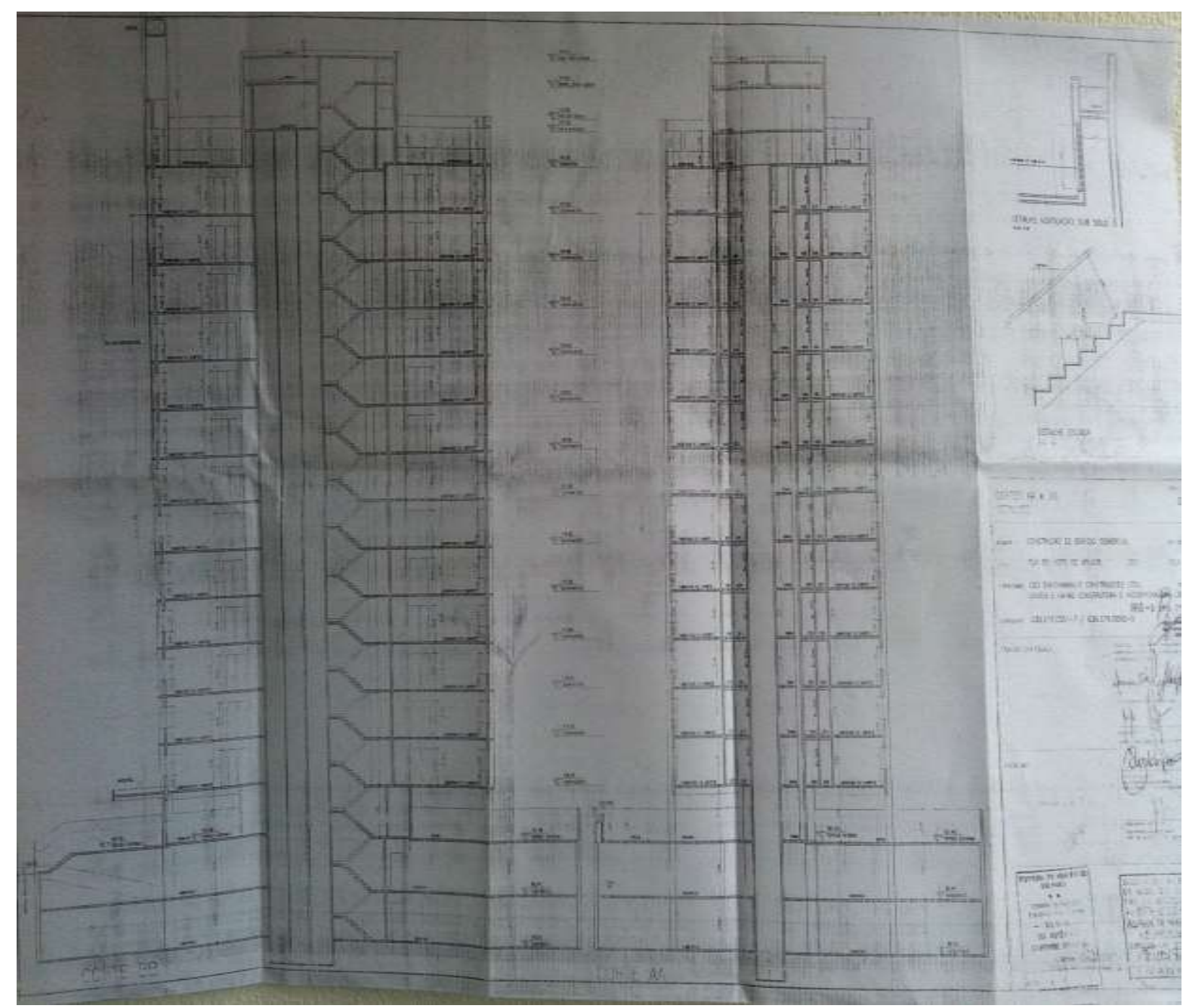

CORTE A-A 